\title{
A molecular perspective on the ageing of marine dissolved organic matter
}

\author{
R. Flerus ${ }^{1, *}$, O. J. Lechtenfeld ${ }^{1, *}$, B. P. Koch ${ }^{1,2, *}$, S. L. McCallister ${ }^{3}$, P. Schmitt-Kopplin ${ }^{4,6}$, R. Benner ${ }^{5}$, K. Kaiser ${ }^{5}$, and \\ G. Kattner ${ }^{1}$ \\ ${ }^{1}$ Alfred Wegener Institute for Polar and Marine Research, Ecological Chemistry, Bremerhaven, Germany \\ ${ }^{2}$ University of Applied Sciences, Bremerhaven, Germany \\ ${ }^{3}$ Virginia Commonwealth University, Department of Biology, Center for Environmental Studies, Richmond, VA, USA \\ ${ }^{4}$ Helmholtz Zentrum München, German Research Center for Environmental Health, Analytical BioGeoChemistry, \\ Neuherberg, Germany \\ ${ }^{5}$ University of South Carolina, Marine Science Program, Columbia, SC, USA \\ ${ }^{6}$ Chair of Analytical Food Chemistry, Technische Universität München, 85354 Freising-Weihenstephan, Germany \\ *These authors equally contributed to this work
}

Correspondence to: B. P. Koch (boris.koch@awi.de)

Received: 27 October 2011 - Published in Biogeosciences Discuss.: 29 November 2011

Revised: 3 April 2012 - Accepted: 5 April 2012 - Published: 1 June 2012

\begin{abstract}
Dissolved organic matter (DOM) was extracted by solid-phase extraction (SPE) from 137 water samples from different climate zones and different depths along an eastern Atlantic Ocean transect. The extracts were analyzed with Fourier transform ion cyclotron resonance mass spectrometry (FT-ICR MS) with electrospray ionization (ESI). $\Delta^{14} \mathrm{C}$ analyses were performed on subsamples of the SPE-DOM. In addition, the amount of dissolved organic carbon was determined for all water and SPE-DOM samples as well as the yield of amino sugars for selected samples. Linear correlations were observed between the magnitudes of $43 \%$ of the FT-ICR mass peaks and the extract $\Delta^{14} \mathrm{C}$ values. Decreasing SPE-DOM $\Delta^{14} \mathrm{C}$ values went along with a shift in the molecular composition to higher average masses $(\mathrm{m} / \mathrm{z})$ and lower hydrogen/carbon $(\mathrm{H} / \mathrm{C})$ ratios. The correlation was used to model the SPE-DOM $\Delta^{14} \mathrm{C}$ distribution for all 137 samples. Based on single mass peaks, a degradation index ( $I_{\mathrm{DEG}}$ ) was developed to compare the degradation state of marine SPE-DOM samples analyzed with FT-ICR MS. A correlation between $\Delta^{14} \mathrm{C}, I_{\mathrm{DEG}}$, DOC values and amino sugar yield supports that SPE-DOM analyzed with FT-ICR MS reflects trends of bulk DOM. DOM weighted normalized mass peak magnitudes were used to compare aged and recent SPE-DOM on a semi-quantitative
\end{abstract}

molecular basis. The magnitude comparison showed a continuum of different degradation rates for the detected compounds. A high proportion of the compounds should persist, possibly modified by partial degradation, in the course of thermohaline circulation. Prokaryotic (bacterial) production, transformation and accumulation of this very stable DOM occur primarily in the upper ocean. This DOM is an important contribution to very old DOM, showing that production and degradation are dynamic processes.

\section{Introduction}

Marine dissolved organic matter (DOM) is one of the major active reservoirs of the global carbon cycle. The amount of marine dissolved organic carbon (DOC) is estimated to be $662 \mathrm{Gt}$, which is comparable to the amount of carbon in atmospheric $\mathrm{CO}_{2}$ (Hedges, 1992; Hansell et al., 2009; Tans, 2010). Since the average age of bulk DOC below the thermocline is about $4000 \mathrm{yr}$ in the Sargasso Sea and about $6000 \mathrm{yr}$ in the central North Pacific, marine DOM plays an important role in long-term carbon storage and sequestration of atmospheric $\mathrm{CO}_{2}$ (Williams and Druffel, 1987; Bauer, 2002). This older DOM pool represents a refractory background with concentrations of 
35-45 $\mu \mathrm{mol} \mathrm{kg}{ }^{-1}$ (Hansell and Carlson, 1998; Ogawa et al., 1999), upon which labile and semi-labile pools of DOM are superimposed in the upper ocean. Numerous studies have examined the fluxes, remineralization and temporal variability of accumulated DOC (e.g. Goldberg et al., 2009; Hansell et al., 2009; Carlson et al., 2010). Jiao et al. (2010) proposed the concept of the microbial carbon pump as a potential process for the production of refractory DOM in surface waters. Hereby, microbes produce the very stable DOM, which persists over very long time scales in the world oceans. However, the mechanisms of production, diagenesis and preservation of highly stable DOM are still unknown. The molecular analysis is particularly challenging as only a minor fraction of the DOM can be analyzed molecularly and identified as carbohydrates, lipids, amino acids and amino sugars (Benner, 2002).

Ultrahigh resolution Fourier transform ion cyclotron resonance mass spectrometry (FT-ICR MS) with electrospray ionization (ESI) was successfully applied to distinguish thousands of compounds of different elemental compositions in ultra-filtered and solid-phase extracted marine DOM (SPE-DOM) (Koch et al., 2005; Hertkorn et al., 2006; Kujawinski et al., 2009). Ultrahigh resolution allows elemental formulas to be assigned for individual mass peaks (Stenson et al., 2003). Water samples of different spatial origin can be distinguished based on the molecular information from FT-ICR MS analysis. However, to date only a few samples have been compared with this technique, preventing a systematic comparison of FT-ICR MS data and additional analytical parameters.

Radiocarbon age and amino sugars are critical diagnostic parameters to assess the production of refractory DOM. The analysis of amino sugars in seawater provides very valuable information on the early diagenesis of DOM (Benner and Kaiser, 2003; Davis et al., 2009; Kaiser and Benner, 2009). Radiocarbon age provides a timeline from carbon fixation in the upper ocean and its subsequent turnover and flux to the deep ocean for bulk DOC and individual components and compound classes (Druffel et al., 1992; Aluwihare et al., 1997; Loh et al., 2004; Repeta and Aluwihare, 2006). Due to the analytical challenge of radiocarbon analysis of bulk DOC, the radiocarbon age has only been determined for a few samples at some locations, including the central North Pacific (Williams and Druffel, 1987; Druffel et al., 1992), the Southern Ocean (Druffel and Bauer, 2000) and the Sargasso Sea (Bauer et al., 1992; Druffel et al., 1992). A handful of additional studies have been performed on $\Delta{ }^{14} \mathrm{C}$ of marine DOM fractions of differing size or chemical components, such as humic isolates, lipid extracts, carbohydrate-like DOM and protein-like DOM. The high molecular weight $(>10 \mathrm{kD}) \mathrm{DOM}$ is of recent age, suggesting greater lability and faster turnover, whereas the low molecular weight $(<1 \mathrm{kD})$ DOM is apparently older (Santschi et al., 1995; Loh et al., 2004). Humic substances isolated with XAD resins are similar to bulk $\mathrm{C}$ pools, with radiocarbon ages only slightly older (Druffel et al., 1989). The oldest age (up to $17000 \mathrm{yr}$ BP) was determined in lipid extracts (Loh et al., 2004). However, each DOM fraction still consists of multiple compounds with a continuum of ages, and consequently the bulk age of DOM represents an average of all the individual compounds. To date, a direct linkage between radiocarbon age and DOM on a molecular level has not been reported.

The aim of this study is to investigate the ageing, processes and associated molecular changes of DOM along an eastern Atlantic Ocean transect. Our combination of FT-ICR MS with radiocarbon age analysis of SPE-DOM from different depths and biogeochemical regions provided a unique opportunity to investigate the age composition and related molecular signatures of a large ocean system. To discuss the data in a broader ecological and biogeochemical context, FT-ICR MS data were combined for the first time with environmental parameters, DOC, amino sugars and bacterial activity, each determined independently. Our ultimate goal was to elucidate molecular trends that are characteristic for the entire Atlantic Ocean.

\section{Materials and methods}

\subsection{Sampling}

Water samples were collected along a transect from $50.2^{\circ} \mathrm{N}$ to $31.4^{\circ} \mathrm{S}$ in the eastern Atlantic Ocean in November 2008 during the cruise ANT-XXV/1 of R/V Polarstern. Surface water was sampled three times per day with a fish sampler, which was fixed alongside the ship, providing a continuous flow of surface water $(\sim 2 \mathrm{~m}$ water depth). Water from $200 \mathrm{~m}$ and the fluorescence maximum was sampled daily with a rosette sampler connected to a CTD, as well as water from seven selected stations from surface to bottom (Fig. 1). Samples for the analysis of DOC and amino sugars were filtered through GF/F filters (Whatman, pre-combusted for $4 \mathrm{~h}, 450{ }^{\circ} \mathrm{C}$ ) and stored in pre-combusted glass ampoules at $-20^{\circ} \mathrm{C}$.

\subsection{DOM extraction}

FT-ICR MS measurement requires the concentration and desalting of marine DOM. Therefore, DOM was extracted on board using solid-phase extraction (SPE), for which the term SPE-DOM will be used in the following. Filtered samples were acidified with $\mathrm{HCl}$ (hydrochloric acid, p.a. grade, Merck) to $\mathrm{pH} 2$. The DOM was extracted using SPE cartridges (PPL, 1g, Varian, Mega Bond Elut) according to Dittmar et al. (2008). The cartridges were rinsed with methanol (LiChrosolv; Merck), followed by acidified ultra-pure water (Milli-Q, pH 2, HCl) and then 51 of seawater was gravity passed through each cartridge. Subsequently, remaining salt was removed with acidified ultra-pure water. After drying with nitrogen gas, DOM was eluted with $5 \mathrm{ml}$ methanol into pre-combusted glass ampoules and stored at $-20^{\circ} \mathrm{C}$. 


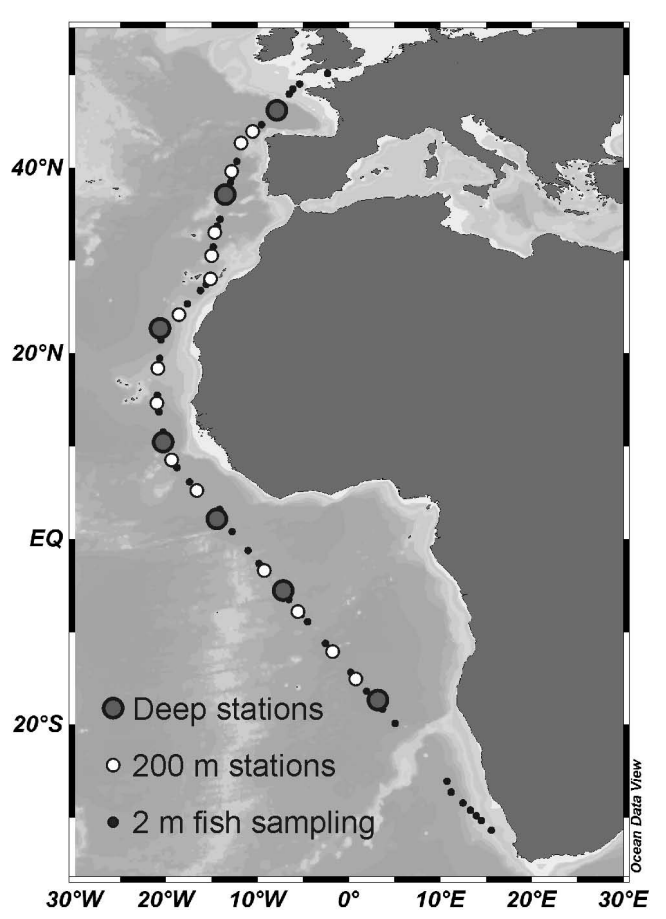

Fig. 1. Map of the sampling locations on the cruise ANT-XXV/1 of RV Polarstern.

\subsection{Analyses}

The DOC concentration was determined by high temperature catalytic oxidation with a Shimadzu TOC-VCPN analyzer. Before analysis water samples were acidified in the auto-sampler and purged with $\mathrm{O}_{2}$ for $5 \mathrm{~min}$. The DOC content of the SPE-DOM was determined by evaporation of $50 \mu \mathrm{l}$ methanol extract re-dissolved in $6.5 \mathrm{ml}$ ultra-pure water.

Bacterioplankton production was estimated by ${ }^{3} \mathrm{H}$-leucine uptake (Smith and Azam, 1992). Triplicate subsamples $(1.5 \mathrm{ml})$ and one trichloroacetic acid-killed control were amended with $5 \mathrm{nM}^{3} \mathrm{H}$-leucine (Amersham, specific activity $\left.160 \mathrm{Ci} \mathrm{mmol}^{-1}\right)$ and incubated at in situ temperature $\left( \pm 2{ }^{\circ} \mathrm{C}\right)$ in the dark. Incubation time varied depending on depth: $\sim 2 \mathrm{~h}$ for upper waters (up to $200 \mathrm{~m}$ ) and up to $12 \mathrm{~h}$ (below $200 \mathrm{~m}$ ). Samples were processed according to Smith and Azam (1992) and radioassayed with a Wallac scintillation counter after addition of $1 \mathrm{ml}$ of Ultima Gold AB scintillation cocktail. The disintegrations per minute (DPM) of the killed control were subtracted from the mean DPM of the corresponding duplicate samples and converted to leucine incorporation rates. A conversion factor of $3.1 \mathrm{~kg} \mathrm{C} \mathrm{mol}^{-1}$ was applied (Kirchman, 1993).

Concentrations of galactosamine (GalN), mannosamine (ManN) and glucosamine $(\mathrm{GlcN})$ were determined by high-performance anion-exchange chromatography coupled to a pulsed amperometric detector (Kaiser and Benner, 2000). After hydrolysis in $3 \mathrm{M} \mathrm{HCl}\left(5 \mathrm{~h}, 100^{\circ} \mathrm{C}\right)$, samples were neutralized with a self-absorbed ion retardation resin
(AG11 A8, Biorad) and stored frozen until analysis. Samples were desalted by solid-phase extraction using Biorad's AG50 X8 resin in the $\mathrm{Na}^{+}$-form before chromatographic separation. Subsequently, GalN, ManN and GlcN were separated isocratically on a Dionex PA20 anion-exchange column with $2 \mathrm{mM} \mathrm{NaOH}$ at a flow rate of $1 \mathrm{ml} \mathrm{min}^{-1}$.

Subsamples of SPE-DOM $(0.2-1 \mathrm{mg} \mathrm{C})$ were quantitatively transferred to combusted $\left(500^{\circ} \mathrm{C}\right)$ quartz tubes $(6 \mathrm{~mm}$ diameter), evaporated under a stream of $\mathrm{N}_{2}$, sealed under vacuum and combusted at $900{ }^{\circ} \mathrm{C}$ to $\mathrm{CO}_{2}$ using a $\mathrm{CuO} / \mathrm{Ag}$ metal catalyst (Sofer, 1980). The $\mathrm{CO}_{2}$ from break seals was subsequently reduced to graphite in an atmosphere of $\mathrm{H}_{2}$ over a cobalt catalyst (Vogel et al., 1987). Graphite targets were analyzed at the Center for Accelerator Mass Spectrometry at Lawrence Livermore National Laboratory. $\Delta^{14} \mathrm{C}$ is defined as the (per mil) deviation of a sample from the ${ }^{14} \mathrm{C}$ activity of a 1950 standard, corrected for fractionation according to Stuvier and Polach (1977). Total measurement uncertainties for $\Delta^{14} \mathrm{C}$ analyses of these samples were typically $\pm 4 \%$. A blank analysis of a SPE cartridge was determined before and no measurable amount of $\mathrm{CO}_{2}$ was found $(<1 \mu \mathrm{g})$.

FT-ICR MS analysis of 137 SPE-DOM samples was performed with an Apex Qe mass spectrometer (Bruker Daltonics), equipped with a $12 \mathrm{~T}$ superconducting magnet (Bruker Biospin) and an Apollo II Dual electrospray source (Bruker). Prior to analysis, SPE-DOM was adjusted to similar DOC concentrations by dilution with methanol (factor 3.1-9.7). The diluted extracts were analysed with ESI in negative ion mode (capillary voltage $-4.2 \mathrm{kV}$, infusion flow rate $2 \mu \mathrm{min}^{-1}$ ). Spectra were calibrated internally with compounds, which were repeatedly identified in marine DOM samples $(\mathrm{m} / \mathrm{z} 339.10854,369.11911,411.12967$, 469.13515, 541.15628; Schmidt et al., 2009; Flerus et al., 2011). 512 scans were added to acquire one spectrum. All ions were singly charged and the mass accuracy was below $0.2 \mathrm{ppm}>$ mass accuracy $>-0.2 \mathrm{ppm}$ for the ions used for the internal calibration.

\subsection{FT-ICR MS data evaluation}

The mass spectra were evaluated in the range $m / z 200-600$. For each identified peak in the spectra (signal to noise $>3$; Data analysis 3.4; Bruker Daltonics), elemental formulas were calculated in the mass accuracy range of \pm 0.5 ppm (e.g. Koch et al., 2005, 2007). The isotopes included for the formula calculation were as follows: ${ }^{12} \mathrm{C}$ $(0-\infty),{ }^{13} \mathrm{C}(0-1),{ }^{1} \mathrm{H}(0-\infty),{ }^{16} \mathrm{O}(0-\infty),{ }^{14} \mathrm{~N}(0-2),{ }^{32} \mathrm{~S}$ $(0-1)$. The average mass accuracy for all assigned peaks was $< \pm 0.2 \mathrm{ppm}$. For unambiguous elemental formula assignment, the "nitrogen-rule" and following thresholds were applied: $\mathrm{O} / \mathrm{C} \leq 1.2$ and $\mathrm{H} / \mathrm{C} \leq 2 \mathrm{C}+2+\mathrm{N}$ (Koch et al., 2005). All formulas with ${ }^{13} \mathrm{C}$ isotopes were removed from the data set as they represent duplicates of the ${ }^{12} \mathrm{C}$ parent molecules. 


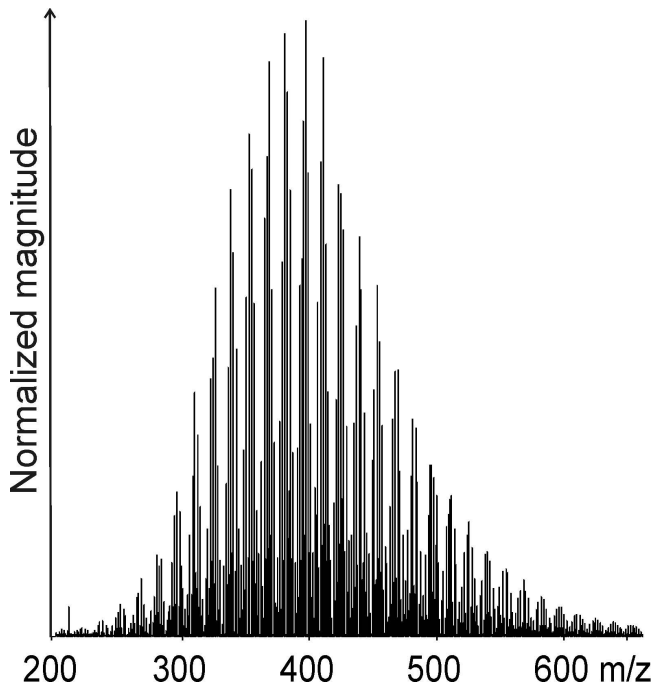

Fig. 2. Negative ESI FT-ICR mass spectrum of a representative marine SPE-DOM sample from the eastern Atlantic Ocean.

Prior to mass spectra comparison, the mass peak magnitudes of each spectrum were normalized to the sum of all identified mass peak magnitudes of the respective spectrum. These relative peak magnitudes are presented in per mill (\%o) and a magnitude cutoff of $0.05 \%$ was applied. All mass peaks present in less than five mass spectra were excluded from the final data set, in favor of identifying bulk trends. Since masses with low signal to noise ratios tend to show less mass accuracy, this procedure allowed an improved formula assignment. Ambiguously identified mass peaks were checked according to the "chemical building block" approach (Koch et al., 2007). Each oxygen atom in a molecular formula could be replaced with a $\mathrm{CH}_{4}$-fragment, forming a pseudo-homologous series with a mass difference, $\Delta m=36.4 \mathrm{mDa}$. Therefore, the number of oxygen atoms in a molecular formula must exceed the number of " $\mathrm{CH}_{4}-\mathrm{O}$ " pseudo-homologous series members; otherwise it is considered as falsely assigned.

Finally, an evaluation data set was obtained showing 2850 mass peaks with only few doubly-assigned molecular formulas (average: $2 \pm 1$ double assignments per sample). On a presence-absence basis and the $0.05 \%$ cutoff, $54 \%$ of the detected molecular formulas were present in more than 135 samples, while $74 \%$ were present in at least 100 samples showing the typical peak magnitude distribution of marine SPE-DOM (Fig. 2). Most mass peaks, which were not present in all samples, showed normalized magnitudes close to the cutoff limit. Due to the high degree of similarity between all samples, our data evaluation was based on normalized peak magnitudes instead of a presence/absence-based approach as previously applied for biomarker approaches in glacial or riverine DOM (Bhatia et al., 2010; Sleighter and Hatcher, 2008).

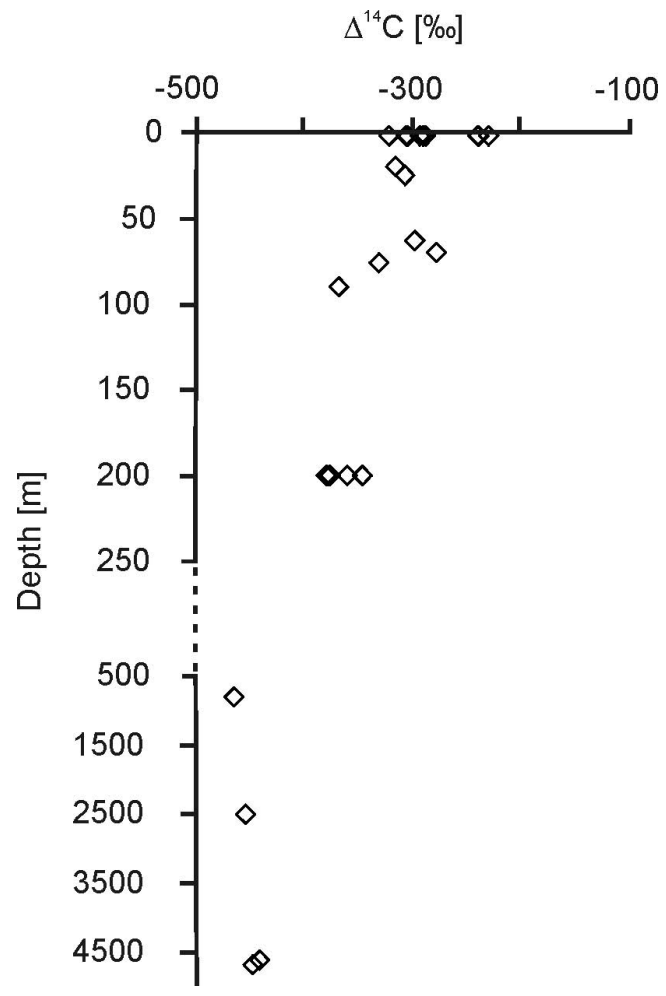

Fig. 3. $\Delta^{14} \mathrm{C}$ values of marine SPE-DOM from the eastern Atlantic Ocean.

\subsection{Statistical analysis}

For statistical analysis we performed a non-parametric twosided Mann-Whitney U-test for the comparison of weighted average parameters of SPE-DOM samples and two groups of peaks. The null hypothesis was that two groups differ by a location shift of " 0 " and the significance level $\alpha$ is 0.01 .

\section{Results and discussion}

$\Delta^{14} \mathrm{C}$ values ranged from a maximum of $-229 \%$ in surface water extracts $(2 \mathrm{~m})$ to $-464 \%$ in deep water extracts ( $>2500 \mathrm{~m}$, Fig. 3 ). The highest surface $\Delta^{14} \mathrm{C}$ values were comparable with the surface $(3 \mathrm{~m}) \Delta^{14} \mathrm{C}$ value determined by Druffel and Bauer (1992) in the Sargasso Sea $(-238 \%$ ). In comparison to the reported values from the Sargasso Sea, our $\Delta^{14} \mathrm{C}$ values in deeper water $(>2 \mathrm{~m}$ ) were slightly more negative, ranging between that of bulk DOC and XAD isolates (Bauer et al., 1992), pointing to an almost representative extraction. However, from polarity-driven reversed-phase chromatography and the lower extraction efficiency for organic nitrogen compared to organic carbon, we know that the method discriminates against highly polar (and presumably small) compounds. 

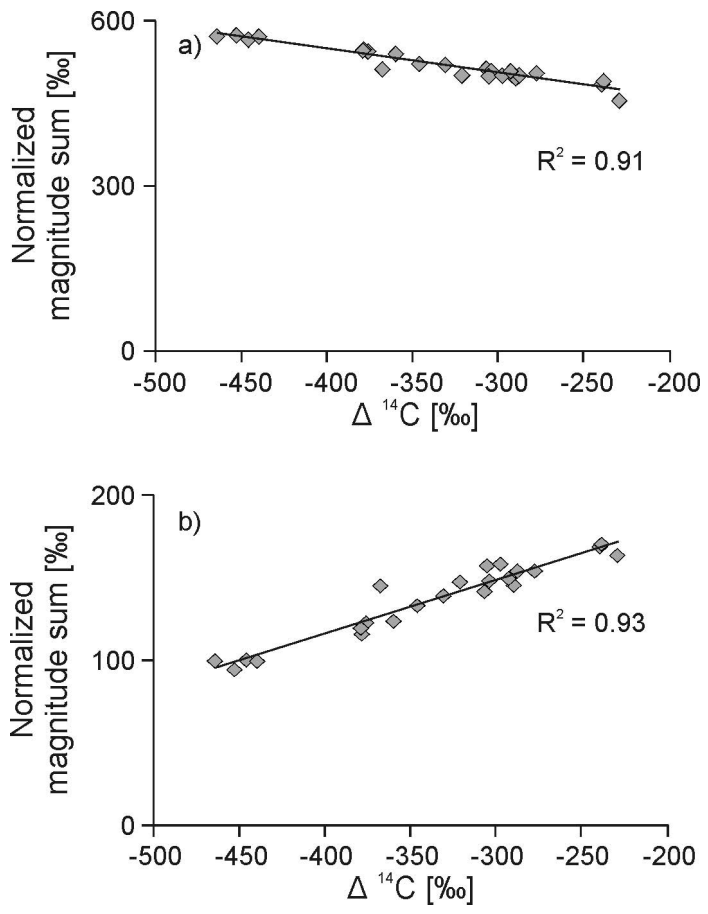

Fig. 4. Normalized magnitude sum [\%o] of (a) negatively and (b) positively correlated FT-ICR mass peaks of eastern Atlantic Ocean SPE-DOM versus $\Delta^{14} \mathrm{C}$ values of the SPE-DOM. The sums ( $\sum$ NEG, $\sum$ POS) were built by adding the normalized magnitudes of the single with $\Delta^{14} \mathrm{C}$ highly negatively or positively correlating mass peaks for each sample.

$43 \%$ of the normalized FT-ICR mass peak magnitudes showed either a significantly linear positive (POS) or negative (NEG) correlation with $\Delta^{14} \mathrm{C}(R>0.5, p<0.01)$ (peaks and elemental formulas are presented in Tables A1 and A2 in Appendix A). The magnitudes of all significantly POS and NEG correlating mass peaks were summed up separately ( $\sum$ POS, $\sum$ NEG), resulting in two average calibration functions (Fig. $4 a, b$ ). The $\sum$ POS and $\sum$ NEG mass peaks account for $61 \pm 1 \%$ of the summed magnitudes of all peaks in each spectrum, therefore representing a large and consistent fraction of peaks for the complete sample set. The two individual calibration functions were then used to calculate two different $\Delta^{14} \mathrm{C}$ values for any of the 137 SPE-DOM samples, both resulting in almost identical $\Delta^{14} \mathrm{C}$ values. Hence, the arithmetic mean of the two calculated $\Delta^{14} \mathrm{C}$ values was used as the final $\Delta^{14} \mathrm{C}$ value $\left(\Delta^{14} \mathrm{C}_{\mathrm{Cal}}\right)$ for each sample. $\Delta^{14} \mathrm{C}_{\mathrm{Cal}}$ values for the upper $200 \mathrm{~m}$ are presented as depth-section (Fig. 5), and for the few deep water samples as individual values (Table 1).

This approach enabled us to apply calculated $\Delta^{14} \mathrm{C}_{\mathrm{Cal}}$ values for the whole sample set, allowing to define the groups of "recent" $\left(\Delta^{14} \mathrm{C}_{\mathrm{Cal}}\right.$ : $\left.>-280 \%, n=29\right)$ and "aged" samples $\left(\Delta{ }^{14} \mathrm{C}_{\mathrm{Cal}}\right.$ : $\left.<-450, n=10\right)$. Within both groups, the peak magnitude distributions were similar. To obtain a semi-quantitative approach of the reactivity of individual

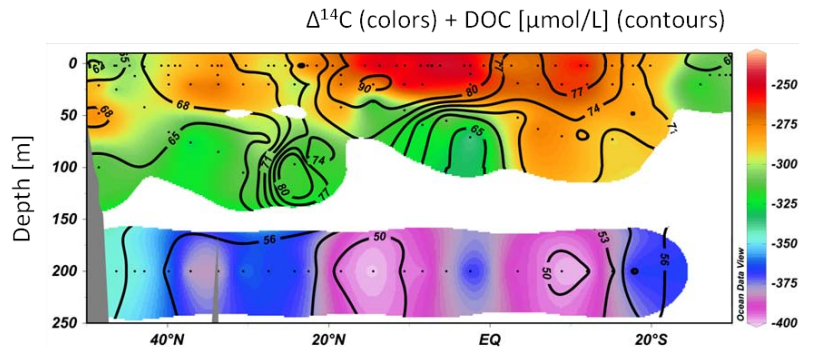

Fig. 5. Calculated SPE-DOM $\Delta^{14} \mathrm{C}$ values (colors) and measured bulk DOC concentrations (contours) in the upper $250 \mathrm{~m}$ of the water column in the eastern Atlantic Ocean. The $\Delta^{14} \mathrm{C}_{\mathrm{Cal}}$ values and the DOC concentrations are significantly positively correlated.

DOM compounds in our Atlantic Ocean sample set, the normalized mass peak magnitudes were weighted by the respective bulk seawater DOC concentration. The relative changes in the magnitudes were calculated using a linear regression model (ordinary least squares, all 137 samples), resulting in predicted decreases of 22 to $167 \%$. A rate of $100 \%$ or more is here defined as compounds with magnitudes falling below the $0.05 \%$ o threshold. Since $100-167 \%$ was a result of the definition and these compounds were still visible as very small mass peaks in the spectra, we will use the term "highly degraded" for this group. The compounds with estimated decreases $>100 \%$ were yet observed to be highly degraded in the oldest SPE-DOM in the Atlantic Ocean. This applied for only $4 \%$ (number $\%$ ) of the compounds. The magnitude weighting resulted in the disappearance of the negative correlations of magnitudes with $\Delta^{14} \mathrm{C}$. In fact, the NEG peaks now exhibited a positive correlation with $\Delta^{14} \mathrm{C}$ as well, suggesting that both, POS and (formerly) NEG correlating compounds detected by FT-ICR MS decrease with age.

\subsection{Molecular characteristics of DOM diagenesis}

We observed clear differences in the molecular characteristics between POS and NEG compounds. The peak magnitudes of the POS compounds were generally much lower than those of the NEG compounds and the average $\mathrm{m} / \mathrm{z}$ was inversely correlated with $\Delta^{14} \mathrm{C}$ values (Fig. 6). Comparing recent and aged samples revealed a highly significant difference (Mann-Whitney U-test; $p<0.01$ ) in the weighted average $m / z$ values of $11.1 \mathrm{Da}$. The magnitude average $\mathrm{m} / \mathrm{z}$ therefore slightly increased from $407.8 \pm 2.1$ for recent to $417.9 \pm 0.8$ for aged SPE-DOM. Previous studies showed a decrease in molecular size from high molecular weight DOM ( $>1 \mathrm{kDa})$ to low molecular weight $\mathrm{DOM}(<1 \mathrm{kDa})$ as a result of increased diagenetic processing (Kaiser and Benner, 2009) and a decreasing bioreactivity (Amon and Benner, 1996). Dittmar and Kattner (2003) also suggested a comparatively higher refractory character for small DOM molecules. However, these previous results were 
Table 1. Calculated SPE-DOM $\Delta^{14} \mathrm{C}_{\mathrm{Cal}}$ values [\%o] and bulk DOC values $\left[\mu \mathrm{mol} \mathrm{L}{ }^{-1}\right]$ in the deep water layers of the eastern Atlantic Ocean.

\begin{tabular}{|c|c|c|c|c|c|c|c|c|c|}
\hline Depth (m) & Parameter & $\begin{array}{r}46^{\circ} \mathrm{N} \\
8^{\circ} \mathrm{W}\end{array}$ & $\begin{array}{r}37^{\circ} \mathrm{N} \\
14^{\circ} \mathrm{W}\end{array}$ & $\begin{array}{r}23^{\circ} \mathrm{N} \\
20^{\circ} \mathrm{W}\end{array}$ & $\begin{array}{r}11^{\circ} \mathrm{N} \\
20^{\circ} \mathrm{W}\end{array}$ & $\begin{array}{r}2^{\circ} \mathrm{S} \\
14^{\circ} \mathrm{W}\end{array}$ & $\begin{array}{c}5^{\circ} \mathrm{S} \\
7^{\circ} \mathrm{W}\end{array}$ & $\begin{array}{l}17^{\circ} \mathrm{S} \\
3^{\circ} \mathrm{W}\end{array}$ & $\begin{array}{l}24^{\circ} \mathrm{S} \\
9^{\circ} \mathrm{W}\end{array}$ \\
\hline $400-500$ & $\Delta^{14} \mathrm{C}(\% \circ)$ & & -402 & & & & & & \\
\hline $800-900$ & $\Delta^{14} \mathrm{C}(\% \circ)$ & & & & -456 & -465 & -448 & -451 & \\
\hline $1100-1800$ & $\Delta^{14} \mathrm{C}(\% \circ)$ & & -436 & -459 & & & & -449 & \\
\hline 2500 & $\Delta^{14} \mathrm{C}(\% \circ)$ & & & -462 & & & & & \\
\hline $4000-5000$ & $\Delta^{14} \mathrm{C}(\% \circ)$ & -443 & -463 & -456 & -450 & -451 & -454 & & \\
\hline $400-500$ & $\operatorname{DOC}\left(\mu \mathrm{mol} \mathrm{L}{ }^{-1}\right)$ & 56 & 58 & & & & & & \\
\hline $800-900$ & $\mathrm{DOC}\left(\mu \mathrm{mol} \mathrm{L}{ }^{-1}\right)$ & & & & 45 & 47 & 46 & 49 & \\
\hline $1100-1800$ & $\operatorname{DOC}\left(\mu \mathrm{mol} \mathrm{L}{ }^{-1}\right)$ & 50 & 48 & & & 52 & 54 & 47 & \\
\hline 2500 & $\operatorname{DOC}\left(\mu \mathrm{mol} \mathrm{L}{ }^{-1}\right)$ & 48 & & 45 & & & & & \\
\hline $4000-5000$ & $\mathrm{DOC}\left(\mu \mathrm{mol} \mathrm{L}{ }^{-1}\right)$ & 48 & 45 & & 47 & & 41 & 47 & 45 \\
\hline
\end{tabular}

obtained using size-related separations such as ultrafiltration and gel permeation chromatography. In contrast, we used absorbent enriched samples (SPE-DOM), preventing a direct comparison with the previous studies. Based on SPE-DOM samples Hertkorn et al. (2012) obtained results that also suggested a similar trend of decreasing SPE-DOM molecular size with depth.

The van Krevelen diagram (Kim et al., 2003) showed differences in the elemental composition of the POS and NEG formulas (Fig. 7). The majority of $\mathrm{CHO}$ compounds of the POS formulas showed high $\mathrm{H} / \mathrm{C}$ ratios $(1.53 \pm 0.2)$, whereas the NEG CHO formulas showed medium to low $\mathrm{H} / \mathrm{C}$ ratios $(1.15 \pm 0.2$, Fig. $7 \mathrm{a}, \mathrm{b})$. Within the region of $\mathrm{H} / \mathrm{C} \leq 1.4$ of the van Krevelen diagram, the average mass for NEG and POS formulas was $m / z, 441$ and $m / z 300$, respectively. Most of the POS formulas containing nitrogen (CHON) showed higher $\mathrm{H} / \mathrm{C}$ ratios $(1.43 \pm 0.2)$. CHON compounds of $\mathrm{NEG}$ formulas occurred only in the low $\mathrm{H} / \mathrm{C}$ region, similarly to the $\mathrm{CHO}$ compounds $(1.16 \pm 0.2$, Fig. $7 \mathrm{c}, \mathrm{d})$. The $\mathrm{H} / \mathrm{C}$ ratio shift also affected the DBE, ranging between 2 and 11 for the POS formulas and between 7 and 14 for the NEG formulas.

Although it is well known that the efficiency of microbial degradation is often related to the polarity of the substrate, we did not observe a shift in the $\mathrm{O} / \mathrm{C}$ ratios with increasing age of the samples. For both NEG and POS groups, $\mathrm{CHO}$ and $\mathrm{CHON}$ compounds showed average $\mathrm{O} / \mathrm{C}$ values of $0.48 \pm 0.3$ and $0.49 \pm 0.2$, respectively, showing no significant differences. With the exception of two mass peaks, CHOS compounds only occurred in the POS formulas having similar $\mathrm{H} / \mathrm{C}$ values as the POS $\mathrm{CHO}$ and $\mathrm{CHON}$ compounds (Fig. 7e, f) with slightly higher $\mathrm{O} / \mathrm{C}$ ratios $(0.6 \pm 0.2)$. However, only little is known about the role of CHOS compounds in DOM and a considerable contribution of anthropogenic input to these compounds cannot be excluded.

The strong molecular similarity, as detected in this and other studies using FT-ICR MS, is considered to represent the refractory molecular background of marine DOM (Koch
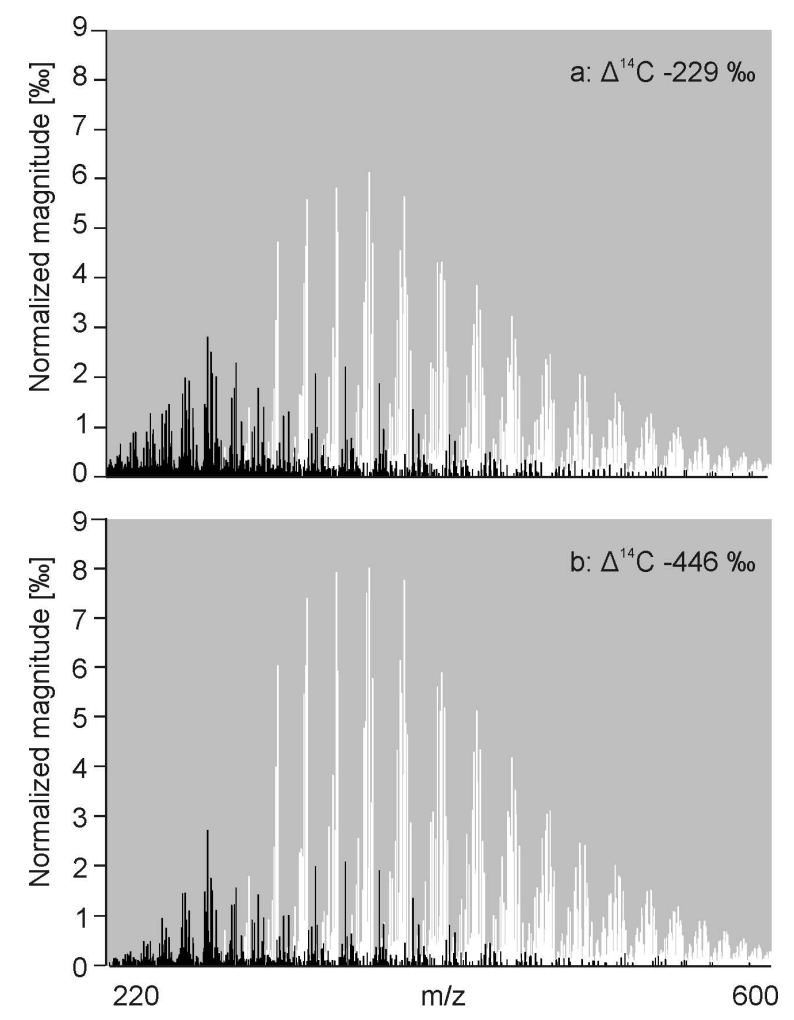

Fig. 6. Selected normalized FT-ICR mass peaks of eastern Atlantic Ocean SPE-DOM. The mass peaks show a significant linear correlation with $\Delta^{14} \mathrm{C}$. (a) Surface sample extract with $\Delta^{14} \mathrm{C}=-229 \%$ and (b) deep sea sample extract with $\Delta{ }^{14} \mathrm{C}=-446 \%$. The black colored masses are positively correlated with $\Delta^{14} \mathrm{C}$ and are present in a higher proportion in the more recent SPE-DOM, whereas the white colored masses are negatively correlated with $\Delta^{14} \mathrm{C}$ and present in a higher proportion in the aged SPE-DOM. The difference in the $\mathrm{m} / \mathrm{z}$ between black and white masses is also reflected in the weighted average $\mathrm{m} / \mathrm{z}$ of the whole SPE-DOM spectra and shifts from 407 (surface sample, $\Delta^{14} \mathrm{C}=-229$ ) to 413 (deep sea sample, $\Delta^{14} \mathrm{C}=-446$ ). 

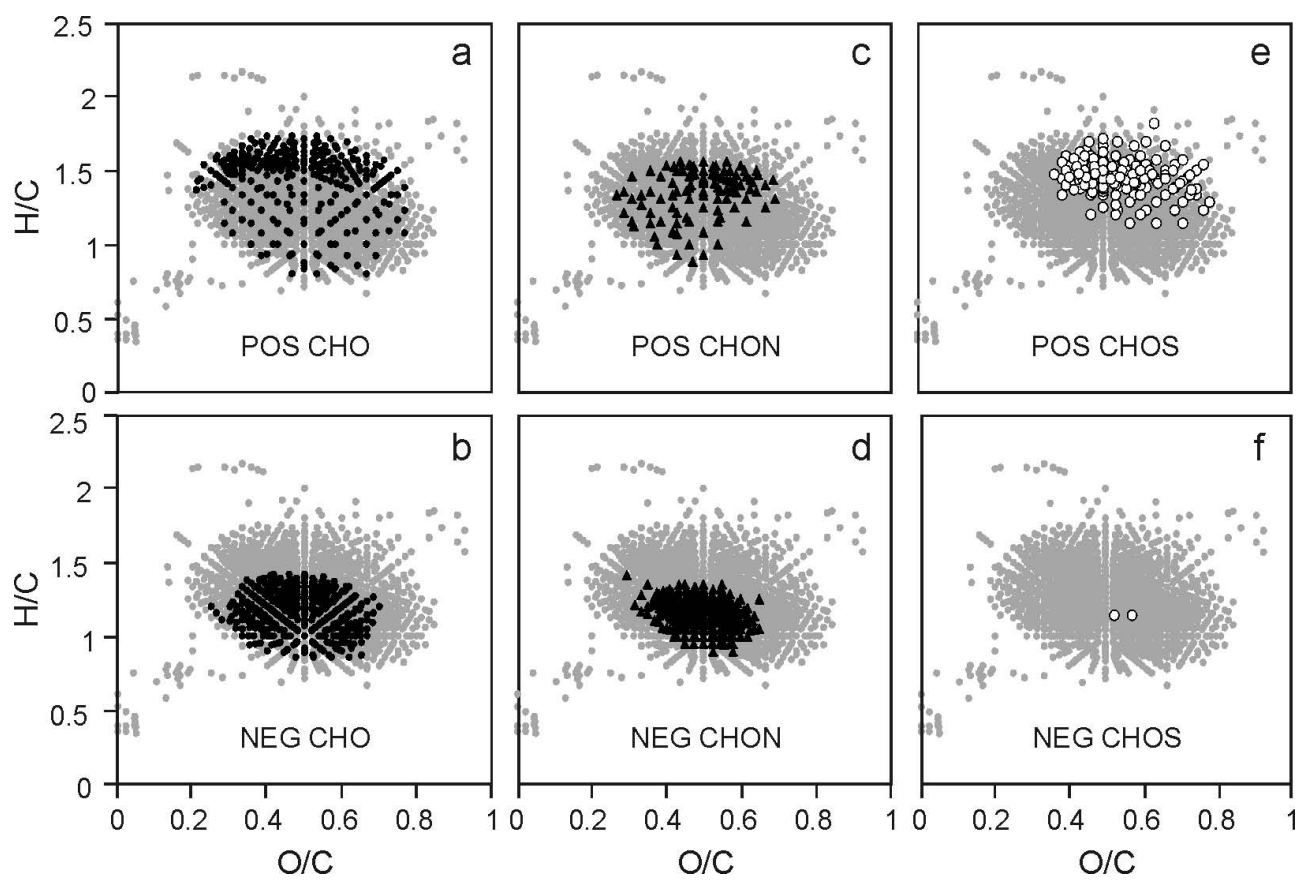

Fig. 7. Van Krevelen diagrams of compounds in eastern Atlantic Ocean SPE-DOM that are significantly correlated with $\Delta^{14} \mathrm{C}(p<$ 0.01): (a) positively with $\mathrm{CHO}$ compounds; (b) negatively with $\mathrm{CHO}$ compounds; (c) positively with CHON compounds; (d) negatively with CHON compounds; (e) positively with CHOS compounds; (f) negatively with CHOS compounds. The grey dots in the background show all compounds found in the majority of Atlantic Ocean water extracts.

et al., 2005; Hertkorn et al., 2006; Gonsior et al., 2011). In our study, we observed depth and age-related trends in the total average elemental composition of the spectra. These trends were similar to the trends observed for the POS and NEG formulas. We found a highly significant difference in the weighted average $\mathrm{H} / \mathrm{C}$ ratios between recent and aged samples (Mann-Whitney U-test, $p<$ 0.01). The magnitude-averaged $\mathrm{H} / \mathrm{C}$ ratios decreased from $1.268 \pm 0.006$ in recent to $1.245 \pm 0.003$ in aged SPE-DOM. Accordingly, the magnitude-averaged DBE increased from $8.03 \pm 0.06$ in recent to $8.43 \pm 0.03$ in aged SPE-DOM. Again, no clear trend was found in the magnitude-averaged $\mathrm{O} / \mathrm{C}$ ratios, and we are currently examining potential reasons for this disparity.

Hertkorn et al. (2006) analysed surface and deep UDOM from the Pacific Ocean using NMR and FT-ICR MS. They identified carboxyl-rich alicyclic molecules (CRAM) as a major constituent in surface and deep UDOM, which was suggested to resist biodegradation. The region occupied by CRAM in the van Krevelen diagram corresponds well with the region of our NEG mass peaks, which are assumed to be compounds resistant to degradation. Hence, CRAM could also be a significant contributor to SPE-DOM. However, it has to be pointed out that the elemental composition can represent a large variety of possible structural isomers (Hertkorn et al., 2007). Nevertheless, a recent study by Witt et al. (2009) demonstrated that the structural variability represented by a single elemental formula in the FT-ICR mass spectra is probably not as high as expected for natural organic matter.

\subsection{East Atlantic Ocean DOM degradation state}

The linear correlation between single mass peaks and SPE-DOM $\Delta{ }^{14} \mathrm{C}$ allows to compare SPE-DOM samples in terms of their degradation state. Since FT-ICR MS is increasingly used for marine DOM studies, we present a degradation index that can be easily used to estimate and compare the degradation state of marine SPE-DOM. To calculate the degradation index, we selected 5 POS (POS Ideg $_{\text {I }}$ ) and 5 NEG ( NEG $_{\text {Ideg }}$ ) formulas (Table 2 ) with a particularly high correlation with the radiocarbon age. The 10 selected masses were also present in $\sim 400$ previously analyzed samples from other locations and environments and therefore suitable to be implemented in a versatile index describing the relative degradation state of an individual sample within a given set of samples. The index $I_{\mathrm{DEG}}$ was calculated using the molecular formulas given in Table 2 and can be directly applied to the raw peak magnitudes:

$$
\begin{aligned}
I_{\mathrm{DEG}}= & \Sigma\left(\text { magnitudes } \mathrm{NEG}_{\mathrm{Ideg}}\right) / \\
& \Sigma\left(\text { magnitudes }\left(\mathrm{NEG}_{\text {Ideg }}+\mathrm{POS}_{\text {Ideg }}\right)\right)
\end{aligned}
$$

The value of $I_{\mathrm{DEG}}$ ranges between $0-1$ and increases with the degradation state of the sample, because the magnitude contribution of NEG formulas increases. We observed 
Table 2. Formulas utilized for magnitude summation in order to calculate the degradation index $I_{\mathrm{DEG}}$.

\begin{tabular}{ll}
\hline $\begin{array}{l}\text { NEG } \\
\text { correlating } \\
\text { compounds }\end{array}$ & $\begin{array}{l}\text { POS } \\
\text { correlating } \\
\text { compounds }\end{array}$ \\
\hline $\mathrm{C}_{21} \mathrm{H}_{26} \mathrm{O}_{11}$ & $\mathrm{C}_{13} \mathrm{H}_{18} \mathrm{O}_{7}$ \\
$\mathrm{C}_{17} \mathrm{H}_{20} \mathrm{O}_{9}$ & $\mathrm{C}_{14} \mathrm{H}_{20} \mathrm{O}_{7}$ \\
$\mathrm{C}_{19} \mathrm{H}_{22} \mathrm{O}_{10}$ & $\mathrm{C}_{15} \mathrm{H}_{22} \mathrm{O}_{7}$ \\
$\mathrm{C}_{20} \mathrm{H}_{22} \mathrm{O}_{10}$ & $\mathrm{C}_{15} \mathrm{H}_{22} \mathrm{O}_{8}$ \\
$\mathrm{C}_{20} \mathrm{H}_{24} \mathrm{O}_{11}$ & $\mathrm{C}_{16} \mathrm{H}_{24} \mathrm{O}_{8}$ \\
\hline
\end{tabular}

however from our database that the absolute value of $I_{\text {DEG }}$ is dependent on instrument, extraction technique and environment. For example, samples from soils and sediments had generally lower values for $I_{\mathrm{DEG}}$ than samples from ocean water (data not shown). If similar sample extracts are measured with the same instrument in series, the $I_{\mathrm{DEG}}$ trends are comparable. However, since no comparable data exist, $\Delta^{14} \mathrm{C}$ values should only be calculated using $I_{\mathrm{DEG}}$ in combination with measured reference $\Delta^{14} \mathrm{C}$ values. Also, C18 extracted samples did not reliably show the respective peaks for the $I_{\mathrm{DEG}}$ calculation.

For our eastern Atlantic Ocean samples, $I_{\mathrm{DEG}}$ was in the range from $0.628-0.756$ for the surface samples (Fig. 8a) and $0.756-0.808$ for deeper water $>200 \mathrm{~m}$ (Table 3 ). $I_{\mathrm{DEG}}$ showed a strong correlation with the $\Delta^{14} \mathrm{C}$ values and the bulk DOC concentrations. In particular, in the upper $200 \mathrm{~m}$ changes in DOC concentrations were reflected in the $I_{\mathrm{DEG}}$. The lowest $I_{\mathrm{DEG}}$ was found in the area with the youngest SPE-DOM, in the upper $25 \mathrm{~m}$ between $2-12^{\circ} \mathrm{N}$ along with the highest DOC concentrations. This was the most stratified region with thermocline depths of $25-30 \mathrm{~m}$. The accumulation of freshly produced DOC in highly stratified surface water was also reported by Carlson et al. (1994) and Goldberg et al. (2009). At $200 \mathrm{~m}$ depth the lowest $I_{\text {DEG }}$ and the youngest SPE-DOM were calculated north of $40^{\circ} \mathrm{N}$. The highest $I_{\mathrm{DEG}}$ as well as the oldest SPE-DOM and lowest bulk DOC concentrations matched with the tropical divergences around $15^{\circ} \mathrm{N}$ and $10^{\circ} \mathrm{S}$, which are upwelling areas. The location of the tropical divergences was obtained from CTD temperature profiles of the cruise. So far, the narrow range and small number of data points of $\Delta^{14} \mathrm{C}$ values, DOC concentrations and FT-ICR MS spectra for deep ( $>500 \mathrm{~m})$ and bottom water samples circumvent a detailed oceanographic discussion of abyssal water masses of terms of DOM degradation.

To support the differentiation in fresh and old DOM, amino sugars were determined directly in bulk water samples as an independent measurement. Amino sugars are bioactive compounds and the DOC-normalized yield of amino sugars is an indicator for the degradation state of DOM (Benner and Kaiser, 2003; Kaiser and Benner, 2009). The significant
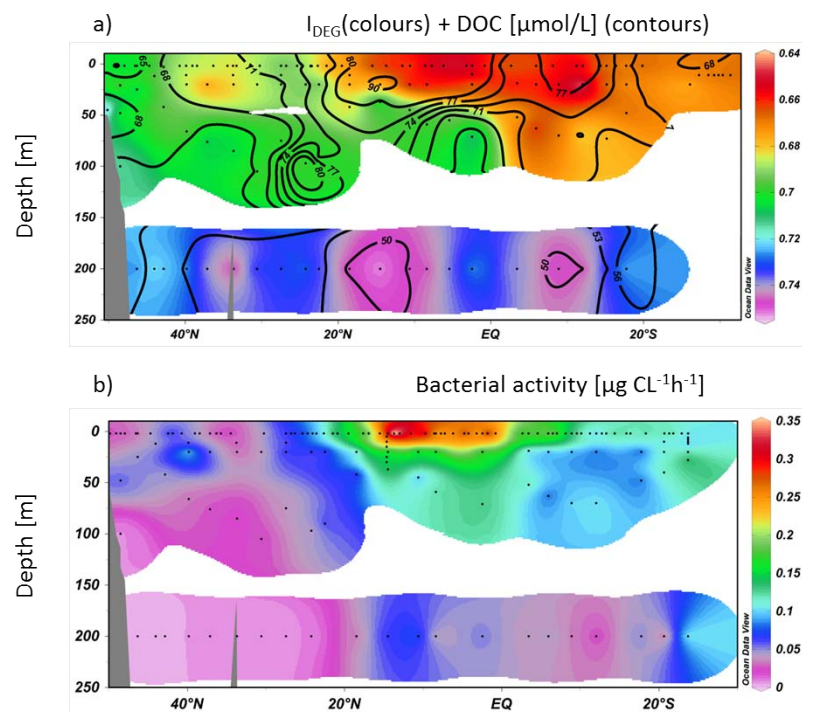

Fig. 8. (a) Values of the degradation index $I_{\mathrm{DEG}}$ for SPE-DOM samples from the eastern Atlantic Ocean (colors) and bulk DOC concentrations (contours); (b) the bacterial activity determined as utilized $\mu \mathrm{g} \mathrm{Cl}^{-1} \mathrm{~h}^{-1}$ in the upper $250 \mathrm{~m}$ of the water column in the eastern Atlantic Ocean. I IEG can be easily calculated and used to estimate and compare the degradation state of marine FT-ICR MS analyzed SPE-DOM. The higher the values of $I_{\mathrm{DEG}}$, the more degraded is the SPE-DOM. I $I_{\mathrm{DEG}}$ and the DOC concentrations are significantly correlated. The bacterial activity maximum coincides with the lowest $I_{\mathrm{DEG}}$, the DOC maximum and the youngest SPEDOM (Fig. 4).

correlation between $\Delta^{14} \mathrm{C}_{\mathrm{Cal}}$ and the yield of amino sugars is consistent with previous observations, indicating that they are more reactive than bulk DOC. These independent results are a good indication that our mass peak magnitude-based $\Delta^{14} \mathrm{C}$ calculation is reasonable (Fig. 9). The exponential relation between the amino sugar yield and $\Delta^{14} \mathrm{C}_{\mathrm{Cal}}$ also suggests that a fraction of the youngest and most bioavailable compounds was not recovered by SPE or was not detected by FT-ICR MS analysis.

\subsection{Degradation continuum and the microbial carbon pump}

Several studies present strategies to explain mechanisms of redistribution of DOM in the water column, based on their $\Delta^{14} \mathrm{C}$ values and two or three component models (Beaupre and Druffel, 2009; Beaupre and Aluwihare, 2010; Hansell et al., 2009; Williams and Druffel, 1987). The models suggest a refractory DOM background fraction and labile or semi-labile fractions with distinct isotopic compositions. Beaupre and Druffel (2009) used 2-component Keeling plots to estimate the radiocarbon age of the background and the fresh DOM fractions. Applying the Keeling plot method to the SPE-DOM samples from the seven deep stations results in similar values for the fresh SPE-DOM fraction 
Table 3. $I_{\mathrm{DEG}}$ values for deep water layers.

\begin{tabular}{rrrrrrrr}
\hline & $46^{\circ} \mathrm{N}$ & $37^{\circ} \mathrm{N}$ & $23^{\circ} \mathrm{N}$ & $11^{\circ} \mathrm{N}$ & $2^{\circ} \mathrm{S}$ & $5^{\circ} \mathrm{S}$ & $17^{\circ} \mathrm{S}$ \\
Depth [m] & $8^{\circ} \mathrm{W}$ & $14^{\circ} \mathrm{W}$ & $20^{\circ} \mathrm{W}$ & $20^{\circ} \mathrm{W}$ & $14^{\circ} \mathrm{W}$ & $7^{\circ} \mathrm{W}$ & $3^{\circ} \mathrm{W}$ \\
\hline $400-500$ & & 0.756 & & & & & \\
$800-900$ & & & & 0.793 & 0.790 & 0.777 & 0.776 \\
$1100-1800$ & & 0.787 & 0.801 & & & & 0.779 \\
2500 & & & 0.807 & & & & \\
$4000-5000$ & 0.798 & 0.808 & 0.805 & 0.787 & 0.785 & 0.788 & \\
\hline
\end{tabular}
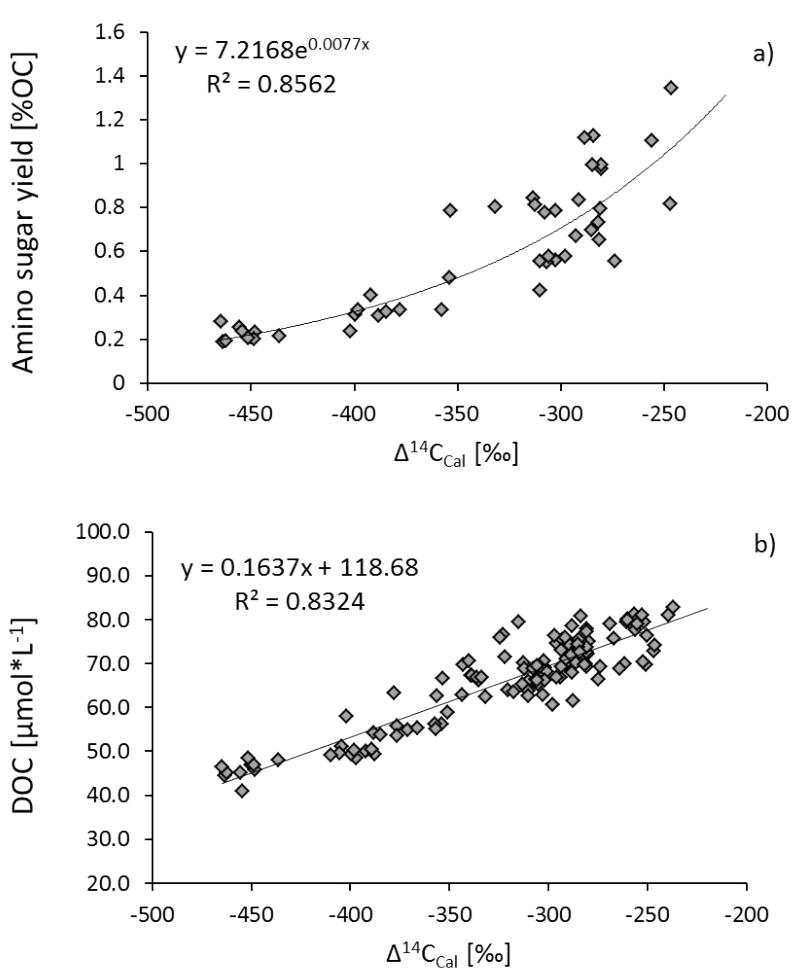

Fig. 9. Correlation and equations of (a) bulk amino sugar yields and (b) bulk DOC concentrations of Atlantic Ocean water and calculated $\Delta^{14} \mathrm{C}$ values of the corresponding SPE-DOM. The correlations indicate the reasonability of the trend in $\Delta^{14} \mathrm{C}_{\mathrm{Cal}}$. The exponential relation between the amino sugar yield and $\Delta{ }^{14} \mathrm{C}_{\mathrm{Cal}}$ also suggests that a fraction of the youngest and most bioavailable compounds was not recovered by SPE or was not detected by FT-ICR MS analysis.

at every station (Table 4). The values are slightly lower than the values reported for the Sargasso Sea (Beaupre and Aluwihare, 2010), but the variation is within the range of reported values for the Pacific Ocean (Beaupre and Druffel, 2009). This provides further evidence that the trends in radiocarbon age of SPE-DOM are comparable to that for the bulk DOC. Beaupre and Druffel (2009) calculated $\Delta^{14} \mathrm{C}$ for the background DOM, but since $\Delta^{14} \mathrm{C}$ was too low for the oldest water sample, they considered a multiple component system.
Our results indeed showed a wide spectrum of DOM reactivity represented by varying slopes of magnitude change with age, supporting our hypothesis of a continuum of DOM reactivity and age. As mentioned above, we assume that the compounds in the FT-ICR mass spectra have been degraded over time, but to varying extents. In the north Central Pacific Ocean (NCP), the lowest $\Delta^{14} \mathrm{C}$ value of bulk DOC is $-546 \%$ (Druffel et al., 1992), which is older than the oldest SPE-DOM in the Atlantic Ocean. Coinciding with the oldest water masses, the DOC concentration in the deep NCP is only $\sim 34 \mu \mathrm{mol} \mathrm{kg}^{-1}$ (Hansell et al., 2009), supporting the hypothesis of a very slow degradation (remineralization) of refractory DOC (Hansell et al., 2012). Based on the correlation between $\Delta^{14} \mathrm{C}_{\mathrm{Cal}}$ of SPE-DOM and DOC concentration (Fig. 9b), we estimated the $\Delta^{14} \mathrm{C}$ values and molecular degradation trends of SPE-DOM during thermohaline circulation. Applying this correlation, the SPE-DOM $\Delta^{14} \mathrm{C}$ in the NCP calculates to $-518 \%$, which is in good agreement with the values reported by Williams and Druffel (1987) and Druffel et al. (1992). To elucidate at which point during the thermohaline circulation a single compound would be highly degraded, we performed a rough estimate using the following assumptions: (i) each mass peak either represents one compound or several compounds with similar degradation rates. This is based on a recent study by Witt et al. (2009) suggesting that the structural variability of a single elemental formula in the FT-ICR mass spectra is probably not as high as expected for natural organic matter; (ii) a compound is regarded as highly degraded when the relative magnitude falls below the cutoff of $0.05 \%$. Using the calibration functions resulting from the correlation between the bulk DOC weighted magnitudes and $\Delta^{14} \mathrm{C}_{\text {cal }}$, a theoretical SPE-DOM $\Delta^{14} \mathrm{C}$ limit $\left(\Delta^{14} \mathrm{C}_{\mathrm{Lim}}\right)$ was calculated at which each compound is considered to be highly degraded. Thus, the proportion of mass peaks can be estimated, which will be highly degraded in the NCP. Since we were interested in general trends, this calculation was performed for compounds that were present in 27-29 of all "young" samples. All compounds with $\Delta^{14} \mathrm{C}_{\mathrm{Lim}}>$ $-518 \%$ are expected to be highly degradable, as they are not supposed to be present in the NCP. This applied for $16 \%$ (number \%) of the compounds. Portions of the remaining compounds will persist for long periods of time (Fig. 10) 
Table 4. Calculated $\Delta^{14} \mathrm{C}$ values of excess SPE-DOM and corresponding Keeling slope values for the seven deep stations of the eastern Atlantic Ocean.

\begin{tabular}{rrr}
\hline Station & $\begin{array}{r}\Delta^{14} \mathrm{C} \text { of excess } \\
\text { SPE-DOM }\end{array}$ & Keeling slope \\
\hline $46^{\circ} \mathrm{N}, 8^{\circ} \mathrm{W}$ & -121 & -6880 \\
$37^{\circ} \mathrm{N}, 14^{\circ} \mathrm{W}$ & 108 & -11394 \\
$23^{\circ} \mathrm{N}, 20^{\circ} \mathrm{W}$ & 17 & -10050 \\
$11^{\circ} \mathrm{N}, 20^{\circ} \mathrm{W}$ & 50 & -9938 \\
$2^{\circ} \mathrm{S}, 14^{\circ} \mathrm{W}$ & 68 & -10203 \\
$5^{\circ} \mathrm{S}, 7^{\circ} \mathrm{W}$ & 76 & -10550 \\
$17^{\circ} \mathrm{S}, 3^{\circ} \mathrm{W}$ & 44 & -10239 \\
\hline
\end{tabular}

and are supposed to contribute to the high average age of DOM. The FT-ICR MS analyzed SPE-DOM represents a fraction of the marine DOM, for which a high portion of $84 \%$ of the compounds (number \%) is expected to persist, possibly modified by partially degradation, during one or more thermohaline cycles through the global ocean circulation. At the same time the compounds are expected to degrade very slowly with a continuum of different rates in the range from 22-167\% (Fig. 10). The relative decreases were calculated using a linear regression model (ordinary least squares, all 137 samples), resulting in predicted decreases $>100 \%$ for some compounds. These compounds were yet observed to be highly degraded in the oldest SPE-DOM in the Atlantic Ocean.

Our results support the hypothesis of a broad and continuous distribution of $\Delta^{14} \mathrm{C}$ ages, as proposed by Bauer et al. (1992). Since only few of the compounds were identified to be highly degraded in the oldest Atlantic Ocean SPE-DOM, compounds of moderate reactivity, which are degraded within month to decades and expected to be present in SPE-DOM, are potentially underrepresented in the FT-ICR mass spectra. Also, the presence of an absolute refractory fraction (i.e. ${ }^{14} \mathrm{C}$ depleted), which is hidden in a mixture with degrading compounds, cannot be excluded. However, since the $\Delta^{14} \mathrm{C}$ trends in SPE-DOM are similar to $\Delta^{14} \mathrm{C}$ trends of bulk DOM, we propose the degradation continuum shown for FT-ICR MS analysed SPE-DOM to be one important pathway in marine DOM degradation. Operational terms such as "labile", "semi-labile", "refractory (recalcitrant)", "background" or "excess" DOM, as used in different studies (Beaupre and Druffel, 2009; Beaupre and Aluwihare, 2010; Hansell et al., 2009; William and Druffel, 1987; Jiao et al., 2010), are generally useful to distinguish among the reactivities of different DOM fractions, but the complexity of DOM reactivity is better described as a continuum.

The microbial carbon pump provides a conceptual framework for a better understanding of the role of microbial processes in the generation of recalcitrant DOM and carbon storage in the ocean (Ogawa et al., 2001; Jiao et al., 2010).

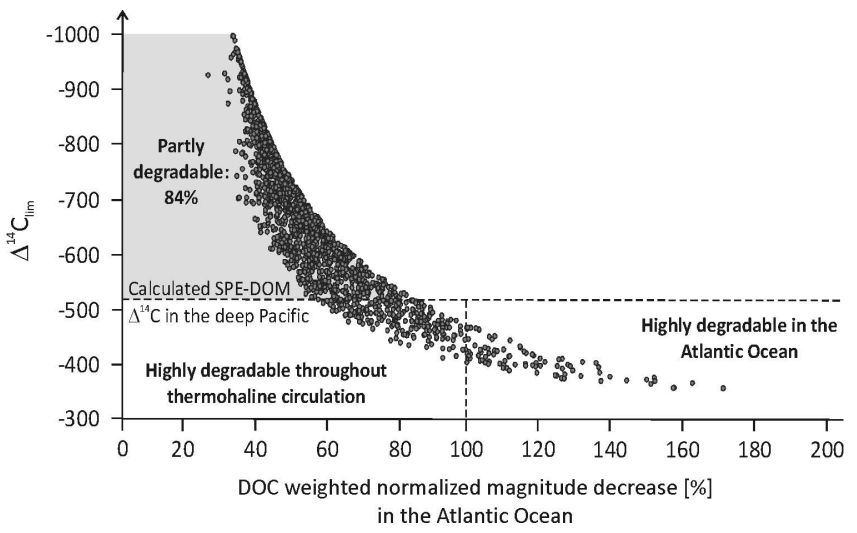

Fig. 10. Calculated limit of $\Delta^{14} \mathrm{C}\left(\Delta^{14} \mathrm{C}_{\mathrm{Lim}}\right)$ for Atlantic Ocean SPE-DOM compounds, represented by FT-ICR mass peaks versus the calculated, DOC weighted normalized magnitude decrease of SPE-DOM in the Atlantic Ocean (x-axis, [\%]). All compounds are expected to decrease with increasing SPE-DOM age, but with different rates (between 22-167\%). The relative decreases were calculated using a linear regression model (ordinary least squares, all 137 samples), resulting in predicted decreases $>100 \%$ for some compounds. These compounds are yet observed to be highly degraded in the oldest SPE-DOM in the Atlantic Ocean. $\Delta^{14} \mathrm{C}_{\text {Lim }}$ is a theoretical SPE-DOM $\Delta^{14} \mathrm{C}$ value, at which a compound is regarded to be highly degraded. All compounds with a $\Delta^{14} \mathrm{C}_{\text {Lim }}>-518 \%$ (SPE-DOM $\Delta{ }^{14} \mathrm{C}$ value estimated for the CNP) are expected to be highly degraded in the oldest water masses. $84 \%$ (number \%) of the compounds should persist, possibly modified by partial degradation throughout thermohaline circulation. The variability of decreasing rates as well as the $\Delta{ }^{14} \mathrm{C}_{\mathrm{Lim}}$ values represent a continuum of different degradation rates for the individual compounds.

It is hypothesized that the transformation of labile and semi-labile DOM through microbial processes leads to the accumulation of recalcitrant DOM in the ocean. Indeed, the highest bacterial activity as well as the maximum abundance of the reactive parameters (DOC, amino sugars and $I_{\mathrm{DEG}}$ ) was determined in surface waters of the highly stratified region between $0-15^{\circ} \mathrm{N}$ (Fig. $7 \mathrm{~b}$ ). The primary production was supposed to have only a minor contribution. A comparison of $I_{\mathrm{DEG}}$ with the TChl-a fluorescence data from the discrete stations (Taylor et al., 2011) showed no clear relationship. Out of all mass peaks, the estimated fraction of the least reactive compounds is at least $61 \%$, accounting for $94 \%$ of the summed magnitudes per sample. We hypothesize that this low reactivity fraction is produced and accumulates in the euphotic zone. Fresh and highly reactive DOM is rapidly consumed by prokaryotes (Carlson and Ducklow, 1996) and partially converted to low reactivity DOM (Ogawa et al., 2001). These recently produced refractory and younger compounds mix with older refractory compounds of similar reactivity in the epipelagic zone. This mixture is then further degraded by bacterial activity (Ogawa and Tanoue, 2003) and thereby aged during the thermohaline circulation. 


\section{Conclusions}

Trends in bulk DOC radiocarbon ages were reflected in the radiocarbon age, determined from a correlation between selected FT-ICR mass peaks and SPE-DOM $\Delta^{14} \mathrm{C}$ values. With this knowledge the degradation state of other marine DOM samples can be estimated by comparing FT-ICR mass peaks. Since this method was only applied for the Atlantic Ocean, it is important to continue these studies in other oceanic regions. For this, the degradation index $I_{\mathrm{DEG}}$ was introduced as a simple tool to evaluate relative degradation states in a set of similarly treated samples. So far, $I_{\mathrm{DEG}}$ is only applied for SPE-DOM samples (PPL extracts) from the Atlantic Ocean and thus has to be further verified.

We propose a degradation continuum of the compounds represented in the FT-ICR mass spectra, but only a minor portion of them are expected to be highly degraded during thermohaline circulation. Prokaryotic (bacterial) production, transformation and accumulation of the very stable DOM occur probably primarily in the upper ocean (Benner and Herndl, 2011). This DOM is an important contribution to very old DOM, showing that production and degradation are dynamic processes. Since bacterial growth, bacterial production or enzymatic activities are influenced by parameters, e.g. temperature or $\mathrm{CO}_{2}$ (Piontek et al., 2009, 2010), a change of these parameters could also influence the processes of refractory DOM production or degradation and as a consequence also the amount of DOM in the world oceans.
It is likely that the microbial carbon pump and the proposed degradation continuum of microbially-produced DOM are parts of several processes taking place concurrently, resulting in the observed average age of DOM samples. To elucidate these complex processes, it is important to further investigate sources, transformations and fates of DOM in the ocean. The FT-ICR MS data provide novel insights into the molecular composition of highly degraded DOM. Microbial degradation experiments and studies of aggregation processes combined with FT-ICR MS will help to gain a better understanding of DOM cycling in the ocean.

Acknowledgements. The authors gratefully acknowledge Anne Stuart for lab assistance, two anonymous reviewers for their helpful comments and the crew of the research vessel "Polarstern" for professional assistance during sample collection.

This work was partially funded by the German Academic Exchange Service (DAAD, project 50023021), the German Science Foundation (KO 2164/8-1), and a National Science Foundation-Ocean Sciences grant OCE-0825403 to S. L. M. and NSF 0713915.

Edited by: G. Herndl 
Table A1. POS molecular formulas: complete list of mass peaks and assigned molecular formulas that showed a highly significant positive correlation $(p<0.01)$ with SPE-DOM $\Delta^{14} \mathrm{C}$.

\begin{tabular}{|c|c|c|c|c|c|}
\hline Elemental Formula & M & Elemental Formula & M & Elemental Formula & M \\
\hline $\mathrm{C}_{12} \mathrm{H}_{14} \mathrm{O}_{4}$ & 222.089209 & $\mathrm{C}_{14} \mathrm{H}_{14} \mathrm{O}_{8}$ & 310.068867 & $\mathrm{C}_{18} \mathrm{H}_{27} \mathrm{O}_{8} \mathrm{~N}_{1}$ & 385.173667 \\
\hline $\mathrm{C}_{13} \mathrm{H}_{18} \mathrm{O}_{3}$ & 222.125594 & $\mathrm{C}_{16} \mathrm{H}_{22} \mathrm{O}_{6}$ & 310.141638 & $\mathrm{C}_{16} \mathrm{H}_{22} \mathrm{O}_{9} \mathrm{~N}_{2}$ & 386.13253 \\
\hline $\mathrm{C}_{11} \mathrm{H}_{12} \mathrm{O}_{5}$ & 224.068474 & $\mathrm{C}_{17} \mathrm{H}_{26} \mathrm{O}_{5}$ & 310.178024 & $\mathrm{C}_{18} \mathrm{H}_{26} \mathrm{O}_{7} \mathrm{~S}_{1}$ & 386.139924 \\
\hline $\mathrm{C}_{12} \mathrm{H}_{16} \mathrm{O}_{4}$ & 224.104859 & $\mathrm{C}_{13} \mathrm{H}_{12} \mathrm{O}_{9}$ & 312.048132 & $\mathrm{C}_{19} \mathrm{H}_{30} \mathrm{O}_{8}$ & 386.194068 \\
\hline $\mathrm{C}_{13} \mathrm{H}_{20} \mathrm{O}_{3}$ & 224.141245 & $\mathrm{C}_{14} \mathrm{H}_{16} \mathrm{O}_{8}$ & 312.084518 & $\mathrm{C}_{17} \mathrm{H}_{25} \mathrm{O}_{9} \mathrm{~N}_{1}$ & 387.152931 \\
\hline $\mathrm{C}_{11} \mathrm{H}_{14} \mathrm{O}_{5}$ & 226.084124 & $\mathrm{C}_{13} \mathrm{H}_{16} \mathrm{O}_{7} \mathrm{~N}_{2}$ & 312.095751 & $\mathrm{C}_{15} \mathrm{H}_{20} \mathrm{O}_{8} \mathrm{~N}_{2} \mathrm{~S}_{1}$ & 388.094036 \\
\hline $\mathrm{C}_{12} \mathrm{H}_{18} \mathrm{O}_{4}$ & 226.120509 & $\mathrm{C}_{15} \mathrm{H}_{20} \mathrm{O}_{7}$ & 312.120903 & $\mathrm{C}_{17} \mathrm{H}_{24} \mathrm{O}_{8} \mathrm{~S}_{1}$ & 388.119188 \\
\hline $\mathrm{C}_{10} \mathrm{H}_{12} \mathrm{O}_{6}$ & 228.063388 & $\mathrm{C}_{16} \mathrm{H}_{24} \mathrm{O}_{6}$ & 312.157289 & $\mathrm{C}_{19} \mathrm{H}_{20} \mathrm{O}_{7} \mathrm{~N}_{2}$ & 388.127051 \\
\hline $\mathrm{C}_{11} \mathrm{H}_{16} \mathrm{O}_{5}$ & 228.099774 & $\mathrm{C}_{13} \mathrm{H}_{15} \mathrm{O}_{8} \mathrm{~N}_{1}$ & 313.079767 & $\mathrm{C}_{17} \mathrm{H}_{24} \mathrm{O}_{10}$ & 388.136947 \\
\hline $\mathrm{C}_{10} \mathrm{H}_{14} \mathrm{O}_{6}$ & 230.079038 & $\mathrm{C}_{14} \mathrm{H}_{19} \mathrm{O}_{7} \mathrm{~N}_{1}$ & 313.116152 & $\mathrm{C}_{18} \mathrm{H}_{28} \mathrm{O}_{7} \mathrm{~S}_{1}$ & 388.155574 \\
\hline $\mathrm{C}_{11} \mathrm{H}_{18} \mathrm{O}_{5}$ & 230.115424 & $\mathrm{C}_{15} \mathrm{H}_{23} \mathrm{O}_{6} \mathrm{~N}_{1}$ & 313.152538 & $\mathrm{C}_{18} \mathrm{H}_{28} \mathrm{O}_{9}$ & 388.173333 \\
\hline $\mathrm{C}_{10} \mathrm{H}_{16} \mathrm{O}_{6}$ & 232.094688 & $\mathrm{C}_{13} \mathrm{H}_{14} \mathrm{O}_{9}$ & 314.063782 & $\mathrm{C}_{19} \mathrm{H}_{32} \mathrm{O}_{8}$ & 388.209718 \\
\hline $\mathrm{C}_{13} \mathrm{H}_{14} \mathrm{O}_{4}$ & 234.089209 & $\mathrm{C}_{14} \mathrm{H}_{18} \mathrm{O}_{8}$ & 314.100168 & $\mathrm{C}_{16} \mathrm{H}_{23} \mathrm{O}_{8} \mathrm{~N}_{1} \mathrm{~S}_{1}$ & 389.114437 \\
\hline $\mathrm{C}_{12} \mathrm{H}_{12} \mathrm{O}_{5}$ & 236.068474 & $\mathrm{C}_{13} \mathrm{H}_{18} \mathrm{O}_{7} \mathrm{~N}_{2}$ & 314.111401 & $\mathrm{C}_{16} \mathrm{H}_{23} \mathrm{O}_{10} \mathrm{~N}_{1}$ & 389.132196 \\
\hline $\mathrm{C}_{13} \mathrm{H}_{16} \mathrm{O}_{4}$ & 236.104859 & $\mathrm{C}_{15} \mathrm{H}_{22} \mathrm{O}_{7}$ & 314.136553 & $\mathrm{C}_{16} \mathrm{H}_{22} \mathrm{O}_{9} \mathrm{~S}_{1}$ & 390.098453 \\
\hline $\mathrm{C}_{14} \mathrm{H}_{20} \mathrm{O}_{3}$ & 236.141245 & $\mathrm{C}_{16} \mathrm{H}_{26} \mathrm{O}_{6}$ & 314.172939 & $\mathrm{C}_{16} \mathrm{H}_{22} \mathrm{O}_{11}$ & 390.116212 \\
\hline $\mathrm{C}_{12} \mathrm{H}_{14} \mathrm{O}_{5}$ & 238.084124 & $\mathrm{C}_{13} \mathrm{H}_{17} \mathrm{O}_{8} \mathrm{~N}_{1}$ & 315.095417 & $\mathrm{C}_{17} \mathrm{H}_{26} \mathrm{O}_{8} \mathrm{~S}_{1}$ & 390.134839 \\
\hline $\mathrm{C}_{13} \mathrm{H}_{18} \mathrm{O}_{4}$ & 238.120509 & $\mathrm{C}_{14} \mathrm{H}_{21} \mathrm{O}_{7} \mathrm{~N}_{1}$ & 315.131802 & $\mathrm{C}_{17} \mathrm{H}_{26} \mathrm{O}_{10}$ & 390.152597 \\
\hline $\mathrm{C}_{11} \mathrm{H}_{13} \mathrm{O}_{5} \mathrm{~N}_{1}$ & 239.079373 & $\mathrm{C}_{13} \mathrm{H}_{16} \mathrm{O}_{7} \mathrm{~S}_{1}$ & 316.061674 & $\mathrm{C}_{18} \mathrm{H}_{30} \mathrm{O}_{9}$ & 390.188983 \\
\hline $\mathrm{C}_{11} \mathrm{H}_{12} \mathrm{O}_{6}$ & 240.063388 & $\mathrm{C}_{13} \mathrm{H}_{16} \mathrm{O}_{9}$ & 316.079432 & $\mathrm{C}_{15} \mathrm{H}_{21} \mathrm{O}_{9} \mathrm{~N}_{1} \mathrm{~S}_{1}$ & 391.093702 \\
\hline $\mathrm{C}_{12} \mathrm{H}_{16} \mathrm{O}_{5}$ & 240.099774 & $\mathrm{C}_{14} \mathrm{H}_{20} \mathrm{O}_{6} \mathrm{~S}_{1}$ & 316.098059 & $\mathrm{C}_{16} \mathrm{H}_{25} \mathrm{O}_{8} \mathrm{~N}_{1} \mathrm{~S}_{1}$ & 391.130088 \\
\hline $\mathrm{C}_{13} \mathrm{H}_{20} \mathrm{O}_{4}$ & 240.136159 & $\mathrm{C}_{14} \mathrm{H}_{20} \mathrm{O}_{8}$ & 316.115818 & $\mathrm{C}_{15} \mathrm{H}_{20} \mathrm{O}_{10} \mathrm{~S}_{1}$ & 392.077718 \\
\hline $\mathrm{C}_{11} \mathrm{H}_{15} \mathrm{O}_{5} \mathrm{~N}_{1}$ & 241.095023 & $\mathrm{C}_{15} \mathrm{H}_{24} \mathrm{O}_{7}$ & 316.152203 & $\mathrm{C}_{16} \mathrm{H}_{24} \mathrm{O}_{9} \mathrm{~S}_{1}$ & 392.114103 \\
\hline $\mathrm{C}_{11} \mathrm{H}_{14} \mathrm{O}_{6}$ & 242.079038 & $\mathrm{C}_{13} \mathrm{H}_{19} \mathrm{O}_{8} \mathrm{~N}_{1}$ & 317.111067 & $\mathrm{C}_{16} \mathrm{H}_{24} \mathrm{O}_{11}$ & 392.131862 \\
\hline $\mathrm{C}_{12} \mathrm{H}_{18} \mathrm{O}_{5}$ & 242.115424 & $\mathrm{C}_{13} \mathrm{H}_{18} \mathrm{O}_{7} \mathrm{~S}_{1}$ & 318.077324 & $\mathrm{C}_{17} \mathrm{H}_{28} \mathrm{O}_{10}$ & 392.168247 \\
\hline $\mathrm{C}_{10} \mathrm{H}_{12} \mathrm{O}_{7}$ & 244.058303 & $\mathrm{C}_{13} \mathrm{H}_{18} \mathrm{O}_{9}$ & 318.095082 & $\mathrm{C}_{22} \mathrm{H}_{32} \mathrm{O}_{6}$ & 392.219889 \\
\hline $\mathrm{C}_{11} \mathrm{H}_{16} \mathrm{O}_{6}$ & 244.094688 & $\mathrm{C}_{14} \mathrm{H}_{22} \mathrm{O}_{6} \mathrm{~S}_{1}$ & 318.113709 & $\mathrm{C}_{14} \mathrm{H}_{18} \mathrm{O}_{11} \mathrm{~S}_{1}$ & 394.056982 \\
\hline $\mathrm{C}_{12} \mathrm{H}_{20} \mathrm{O}_{5}$ & 244.131074 & $\mathrm{C}_{16} \mathrm{H}_{18} \mathrm{O}_{5} \mathrm{~N}_{2}$ & 318.121572 & $\mathrm{C}_{15} \mathrm{H}_{22} \mathrm{O}_{10} \mathrm{~S}_{1}$ & 394.093368 \\
\hline $\mathrm{C}_{10} \mathrm{H}_{14} \mathrm{O}_{7}$ & 246.073953 & $\mathrm{C}_{14} \mathrm{H}_{22} \mathrm{O}_{8}$ & 318.131468 & $\mathrm{C}_{21} \mathrm{H}_{32} \mathrm{O}_{7}$ & 396.214803 \\
\hline $\mathrm{C}_{11} \mathrm{H}_{18} \mathrm{O}_{6}$ & 246.110338 & $\mathrm{C}_{15} \mathrm{H}_{26} \mathrm{O}_{7}$ & 318.167853 & $\mathrm{C}_{21} \mathrm{H}_{34} \mathrm{O}_{7}$ & 398.230453 \\
\hline $\mathrm{C}_{13} \mathrm{H}_{12} \mathrm{O}_{5}$ & 248.068474 & $\mathrm{C}_{19} \mathrm{H}_{26} \mathrm{O}_{4}$ & 318.183109 & $\mathrm{C}_{19} \mathrm{H}_{29} \mathrm{O}_{8} \mathrm{~N}_{1}$ & 399.189317 \\
\hline $\mathrm{C}_{14} \mathrm{H}_{16} \mathrm{O}_{4}$ & 248.104859 & $\mathrm{C}_{15} \mathrm{H}_{12} \mathrm{O}_{8}$ & 320.053217 & $\mathrm{C}_{16} \mathrm{H}_{20} \mathrm{O}_{8} \mathrm{~N}_{2} \mathrm{~S}_{1}$ & 400.094036 \\
\hline $\mathrm{C}_{13} \mathrm{H}_{15} \mathrm{O}_{4} \mathrm{~N}_{1}$ & 249.100108 & $\mathrm{C}_{12} \mathrm{H}_{16} \mathrm{O}_{8} \mathrm{~S}_{1}$ & 320.056588 & $\mathrm{C}_{17} \mathrm{H}_{24} \mathrm{O}_{9} \mathrm{~N}_{2}$ & 400.14818 \\
\hline $\mathrm{C}_{12} \mathrm{H}_{10} \mathrm{O}_{6}$ & 250.047738 & $\mathrm{C}_{13} \mathrm{H}_{20} \mathrm{O}_{7} \mathrm{~S}_{1}$ & 320.092974 & $\mathrm{C}_{19} \mathrm{H}_{28} \mathrm{O}_{7} \mathrm{~S}_{1}$ & 400.155574 \\
\hline $\mathrm{C}_{13} \mathrm{H}_{14} \mathrm{O}_{5}$ & 250.084124 & $\mathrm{C}_{13} \mathrm{H}_{20} \mathrm{O}_{9}$ & 320.110732 & $\mathrm{C}_{20} \mathrm{H}_{32} \mathrm{O}_{8}$ & 400.209718 \\
\hline $\mathrm{C}_{14} \mathrm{H}_{18} \mathrm{O}_{4}$ & 250.120509 & $\mathrm{C}_{14} \mathrm{H}_{24} \mathrm{O}_{8}$ & 320.147118 & $\mathrm{C}_{17} \mathrm{H}_{23} \mathrm{O}_{8} \mathrm{~N}_{1} \mathrm{~S}_{1}$ & 401.114437 \\
\hline $\mathrm{C}_{12} \mathrm{H}_{13} \mathrm{O}_{5} \mathrm{~N}_{1}$ & 251.079373 & $\mathrm{C}_{15} \mathrm{H}_{14} \mathrm{O}_{8}$ & 322.068867 & $\mathrm{C}_{17} \mathrm{H}_{23} \mathrm{O}_{10} \mathrm{~N}_{1}$ & 401.132196 \\
\hline $\mathrm{C}_{13} \mathrm{H}_{17} \mathrm{O}_{4} \mathrm{~N}_{1}$ & 251.115758 & $\mathrm{C}_{12} \mathrm{H}_{18} \mathrm{O}_{8} \mathrm{~S}_{1}$ & 322.072238 & $\mathrm{C}_{18} \mathrm{H}_{27} \mathrm{O}_{9} \mathrm{~N}_{1}$ & 401.168582 \\
\hline $\mathrm{C}_{12} \mathrm{H}_{12} \mathrm{O}_{6}$ & 252.063388 & $\mathrm{C}_{13} \mathrm{H}_{22} \mathrm{O}_{7} \mathrm{~S}_{1}$ & 322.108624 & $\mathrm{C}_{16} \mathrm{H}_{22} \mathrm{O}_{10} \mathrm{~N}_{2}$ & 402.127445 \\
\hline $\mathrm{C}_{13} \mathrm{H}_{16} \mathrm{O}_{5}$ & 252.099774 & $\mathrm{C}_{18} \mathrm{H}_{26} \mathrm{O}_{5}$ & 322.178024 & $\mathrm{C}_{18} \mathrm{H}_{26} \mathrm{O}_{8} \mathrm{~S}_{1}$ & 402.134839 \\
\hline $\mathrm{C}_{12} \mathrm{H}_{16} \mathrm{O}_{4} \mathrm{~N}_{2}$ & 252.111007 & $\mathrm{C}_{14} \mathrm{H}_{12} \mathrm{O}_{9}$ & 324.048132 & $\mathrm{C}_{18} \mathrm{H}_{26} \mathrm{O}_{10}$ & 402.152597 \\
\hline $\mathrm{C}_{14} \mathrm{H}_{20} \mathrm{O}_{4}$ & 252.136159 & $\mathrm{C}_{12} \mathrm{H}_{20} \mathrm{O}_{8} \mathrm{~S}_{1}$ & 324.087888 & $\mathrm{C}_{19} \mathrm{H}_{30} \mathrm{O}_{9}$ & 402.188983 \\
\hline $\mathrm{C}_{12} \mathrm{H}_{15} \mathrm{O}_{5} \mathrm{~N}_{1}$ & 253.095023 & $\mathrm{C}_{18} \mathrm{H}_{28} \mathrm{O}_{5}$ & 324.193674 & $\mathrm{C}_{17} \mathrm{H}_{25} \mathrm{O}_{10} \mathrm{~N}_{1}$ & 403.147846 \\
\hline $\mathrm{C}_{13} \mathrm{H}_{19} \mathrm{O}_{4} \mathrm{~N}_{1}$ & 253.131408 & $\mathrm{C}_{17} \mathrm{H}_{26} \mathrm{O}_{6}$ & 326.172939 & $\mathrm{C}_{17} \mathrm{H}_{24} \mathrm{O}_{9} \mathrm{~S}_{1}$ & 404.114103 \\
\hline $\mathrm{C}_{12} \mathrm{H}_{14} \mathrm{O}_{6}$ & 254.079038 & $\mathrm{C}_{15} \mathrm{H}_{21} \mathrm{O}_{7} \mathrm{~N}_{1}$ & 327.131802 & $\mathrm{C}_{17} \mathrm{H}_{24} \mathrm{O}_{11}$ & 404.131862 \\
\hline $\mathrm{C}_{13} \mathrm{H}_{18} \mathrm{O}_{5}$ & 254.115424 & $\mathrm{C}_{14} \mathrm{H}_{20} \mathrm{O}_{7} \mathrm{~N}_{2}$ & 328.127051 & $\mathrm{C}_{18} \mathrm{H}_{28} \mathrm{O}_{8} \mathrm{~S}_{1}$ & 404.150489 \\
\hline $\mathrm{C}_{14} \mathrm{H}_{22} \mathrm{O}_{4}$ & 254.151809 & $\mathrm{C}_{16} \mathrm{H}_{24} \mathrm{O}_{7}$ & 328.152203 & $\mathrm{C}_{18} \mathrm{H}_{28} \mathrm{O}_{10}$ & 404.168247 \\
\hline $\mathrm{C}_{11} \mathrm{H}_{13} \mathrm{O}_{6} \mathrm{~N}_{1}$ & 255.074287 & $\mathrm{C}_{17} \mathrm{H}_{28} \mathrm{O}_{6}$ & 328.188589 & $\mathrm{C}_{19} \mathrm{H}_{32} \mathrm{O}_{9}$ & 404.204633 \\
\hline $\mathrm{C}_{12} \mathrm{H}_{17} \mathrm{O}_{5} \mathrm{~N}_{1}$ & 255.110673 & $\mathrm{C}_{14} \mathrm{H}_{19} \mathrm{O}_{8} \mathrm{~N}_{1}$ & 329.111067 & $\mathrm{C}_{16} \mathrm{H}_{23} \mathrm{O}_{9} \mathrm{~N}_{1} \mathrm{~S}_{1}$ & 405.109352 \\
\hline $\mathrm{C}_{11} \mathrm{H}_{12} \mathrm{O}_{7}$ & 256.058303 & $\mathrm{C}_{15} \mathrm{H}_{23} \mathrm{O}_{7} \mathrm{~N}_{1}$ & 329.147452 & $\mathrm{C}_{16} \mathrm{H}_{23} \mathrm{O}_{11} \mathrm{~N}_{1}$ & 405.127111 \\
\hline $\mathrm{C}_{12} \mathrm{H}_{16} \mathrm{O}_{6}$ & 256.094688 & $\mathrm{C}_{13} \mathrm{H}_{14} \mathrm{O}_{10}$ & 330.058697 & $\mathrm{C}_{17} \mathrm{H}_{26} \mathrm{O}_{9} \mathrm{~S}_{1}$ & 406.129753 \\
\hline $\mathrm{C}_{13} \mathrm{H}_{20} \mathrm{O}_{5}$ & 256.131074 & $\mathrm{C}_{14} \mathrm{H}_{18} \mathrm{O}_{9}$ & 330.095082 & $\mathrm{C}_{17} \mathrm{H}_{26} \mathrm{O}_{11}$ & 406.147512 \\
\hline $\mathrm{C}_{11} \mathrm{H}_{15} \mathrm{O}_{6} \mathrm{~N}_{1}$ & 257.089937 & $\mathrm{C}_{15} \mathrm{H}_{22} \mathrm{O}_{6} \mathrm{~S}_{1}$ & 330.113709 & $\mathrm{C}_{18} \mathrm{H}_{30} \mathrm{O}_{10}$ & 406.183897 \\
\hline $\mathrm{C}_{11} \mathrm{H}_{14} \mathrm{O}_{7}$ & 258.073953 & $\mathrm{C}_{15} \mathrm{H}_{22} \mathrm{O}_{8}$ & 330.131468 & $\mathrm{C}_{15} \mathrm{H}_{20} \mathrm{O}_{11} \mathrm{~S}_{1}$ & 408.072632 \\
\hline
\end{tabular}


Table A1. Continued.

\begin{tabular}{|c|c|c|c|c|c|}
\hline Elemental Formula & M & Elemental Formula & M & Elemental Formula & M \\
\hline $\mathrm{C}_{12} \mathrm{H}_{18} \mathrm{O}_{6}$ & 258.110338 & $\mathrm{C}_{16} \mathrm{H}_{26} \mathrm{O}_{7}$ & 330.167853 & $\mathrm{C}_{16} \mathrm{H}_{24} \mathrm{O}_{10} \mathrm{~S}_{1}$ & 408.109018 \\
\hline $\mathrm{C}_{13} \mathrm{H}_{22} \mathrm{O}_{5}$ & 258.146724 & $\mathrm{C}_{13} \mathrm{H}_{17} \mathrm{O}_{9} \mathrm{~N}_{1}$ & 331.090331 & $\mathrm{C}_{15} \mathrm{H}_{22} \mathrm{O}_{11} \mathrm{~S}_{1}$ & 410.088282 \\
\hline $\mathrm{C}_{11} \mathrm{H}_{16} \mathrm{O}_{7}$ & 260.089603 & $\mathrm{C}_{14} \mathrm{H}_{21} \mathrm{O}_{8} \mathrm{~N}_{1}$ & 331.126717 & $\mathrm{C}_{22} \mathrm{H}_{34} \mathrm{O}_{7}$ & 410.230453 \\
\hline $\mathrm{C}_{12} \mathrm{H}_{20} \mathrm{O}_{6}$ & 260.125988 & $\mathrm{C}_{13} \mathrm{H}_{16} \mathrm{O}_{8} \mathrm{~S}_{1}$ & 332.056588 & $\mathrm{C}_{21} \mathrm{H}_{32} \mathrm{O}_{8}$ & 412.209718 \\
\hline $\mathrm{C}_{14} \mathrm{H}_{14} \mathrm{O}_{5}$ & 262.084124 & $\mathrm{C}_{13} \mathrm{H}_{16} \mathrm{O}_{10}$ & 332.074347 & $\mathrm{C}_{19} \mathrm{H}_{26} \mathrm{O}_{8} \mathrm{~S}_{1}$ & 414.134839 \\
\hline $\mathrm{C}_{11} \mathrm{H}_{18} \mathrm{O}_{5} \mathrm{~S}_{1}$ & 262.087494 & $\mathrm{C}_{14} \mathrm{H}_{20} \mathrm{O}_{7} \mathrm{~S}_{1}$ & 332.092974 & $\mathrm{C}_{18} \mathrm{H}_{26} \mathrm{O}_{9} \mathrm{~N}_{2}$ & 414.16383 \\
\hline $\mathrm{C}_{11} \mathrm{H}_{18} \mathrm{O}_{7}$ & 262.105253 & $\mathrm{C}_{16} \mathrm{H}_{16} \mathrm{O}_{6} \mathrm{~N}_{2}$ & 332.100836 & $\mathrm{C}_{21} \mathrm{H}_{34} \mathrm{O}_{8}$ & 414.225368 \\
\hline $\mathrm{C}_{14} \mathrm{H}_{17} \mathrm{O}_{4} \mathrm{~N}_{1}$ & 263.115758 & $\mathrm{C}_{14} \mathrm{H}_{20} \mathrm{O}_{9}$ & 332.110732 & $\mathrm{C}_{19} \mathrm{H}_{29} \mathrm{O}_{9} \mathrm{~N}_{1}$ & 415.184232 \\
\hline $\mathrm{C}_{13} \mathrm{H}_{12} \mathrm{O}_{6}$ & 264.063388 & $\mathrm{C}_{15} \mathrm{H}_{24} \mathrm{O}_{6} \mathrm{~S}_{1}$ & 332.129359 & $\mathrm{C}_{17} \mathrm{H}_{24} \mathrm{O}_{10} \mathrm{~N}_{2}$ & 416.143095 \\
\hline $\mathrm{C}_{10} \mathrm{H}_{16} \mathrm{O}_{6} \mathrm{~S}_{1}$ & 264.066759 & $\mathrm{C}_{15} \mathrm{H}_{24} \mathrm{O}_{8}$ & 332.147118 & $\mathrm{C}_{19} \mathrm{H}_{28} \mathrm{O}_{8} \mathrm{~S}_{1}$ & 416.150489 \\
\hline $\mathrm{C}_{14} \mathrm{H}_{16} \mathrm{O}_{5}$ & 264.099774 & $\mathrm{C}_{16} \mathrm{H}_{14} \mathrm{O}_{8}$ & 334.068867 & $\mathrm{C}_{19} \mathrm{H}_{28} \mathrm{O}_{10}$ & 416.168247 \\
\hline $\mathrm{C}_{13} \mathrm{H}_{15} \mathrm{O}_{5} \mathrm{~N}_{1}$ & 265.095023 & $\mathrm{C}_{13} \mathrm{H}_{18} \mathrm{O}_{8} \mathrm{~S}_{1}$ & 334.072238 & $\mathrm{C}_{20} \mathrm{H}_{32} \mathrm{O}_{9}$ & 416.204633 \\
\hline $\mathrm{C}_{14} \mathrm{H}_{19} \mathrm{O}_{4} \mathrm{~N}_{1}$ & 265.131408 & $\mathrm{C}_{13} \mathrm{H}_{18} \mathrm{O}_{10}$ & 334.089997 & $\mathrm{C}_{18} \mathrm{H}_{27} \mathrm{O}_{10} \mathrm{~N}_{1}$ & 417.163496 \\
\hline $\mathrm{C}_{12} \mathrm{H}_{10} \mathrm{O}_{7}$ & 266.042653 & $\mathrm{C}_{14} \mathrm{H}_{22} \mathrm{O}_{7} \mathrm{~S}_{1}$ & 334.108624 & $\mathrm{C}_{18} \mathrm{H}_{26} \mathrm{O}_{9} \mathrm{~S}_{1}$ & 418.129753 \\
\hline $\mathrm{C}_{13} \mathrm{H}_{14} \mathrm{O}_{6}$ & 266.079038 & $\mathrm{C}_{14} \mathrm{H}_{22} \mathrm{O}_{9}$ & 334.126382 & $\mathrm{C}_{18} \mathrm{H}_{26} \mathrm{O}_{11}$ & 418.147512 \\
\hline $\mathrm{C}_{14} \mathrm{H}_{18} \mathrm{O}_{5}$ & 266.115424 & $\mathrm{C}_{15} \mathrm{H}_{26} \mathrm{O}_{8}$ & 334.162768 & $\mathrm{C}_{19} \mathrm{H}_{30} \mathrm{O}_{8} \mathrm{~S}_{1}$ & 418.166139 \\
\hline $\mathrm{C}_{15} \mathrm{H}_{22} \mathrm{O}_{4}$ & 266.151809 & $\mathrm{C}_{12} \mathrm{H}_{16} \mathrm{O}_{9} \mathrm{~S}_{1}$ & 336.051503 & $\mathrm{C}_{19} \mathrm{H}_{30} \mathrm{O}_{10}$ & 418.183897 \\
\hline $\mathrm{C}_{12} \mathrm{H}_{13} \mathrm{O}_{6} \mathrm{~N}_{1}$ & 267.074287 & $\mathrm{C}_{13} \mathrm{H}_{20} \mathrm{O}_{8} \mathrm{~S}_{1}$ & 336.087888 & $\mathrm{C}_{17} \mathrm{H}_{25} \mathrm{O}_{9} \mathrm{~N}_{1} \mathrm{~S}_{1}$ & 419.125002 \\
\hline $\mathrm{C}_{13} \mathrm{H}_{17} \mathrm{O}_{5} \mathrm{~N}_{1}$ & 267.110673 & $\mathrm{C}_{14} \mathrm{H}_{24} \mathrm{O}_{7} \mathrm{~S}_{1}$ & 336.124274 & $\mathrm{C}_{17} \mathrm{H}_{25} \mathrm{O}_{11} \mathrm{~N}_{1}$ & 419.142761 \\
\hline $\mathrm{C}_{12} \mathrm{H}_{12} \mathrm{O}_{7}$ & 268.058303 & $\mathrm{C}_{19} \mathrm{H}_{28} \mathrm{O}_{5}$ & 336.193674 & $\mathrm{C}_{17} \mathrm{H}_{24} \mathrm{O}_{10} \mathrm{~S}_{1}$ & 420.109018 \\
\hline $\mathrm{C}_{13} \mathrm{H}_{16} \mathrm{O}_{6}$ & 268.094688 & $\mathrm{C}_{12} \mathrm{H}_{18} \mathrm{O}_{9} \mathrm{~S}_{1}$ & 338.067153 & $\mathrm{C}_{17} \mathrm{H}_{24} \mathrm{O}_{12}$ & 420.126776 \\
\hline $\mathrm{C}_{12} \mathrm{H}_{16} \mathrm{O}_{5} \mathrm{~N}_{2}$ & 268.105922 & $\mathrm{C}_{13} \mathrm{H}_{22} \mathrm{O}_{8} \mathrm{~S}_{1}$ & 338.103538 & $\mathrm{C}_{18} \mathrm{H}_{28} \mathrm{O}_{9} \mathrm{~S}_{1}$ & 420.145403 \\
\hline $\mathrm{C}_{14} \mathrm{H}_{20} \mathrm{O}_{5}$ & 268.131074 & $\mathrm{C}_{18} \mathrm{H}_{26} \mathrm{O}_{6}$ & 338.172939 & $\mathrm{C}_{18} \mathrm{H}_{28} \mathrm{O}_{11}$ & 420.163162 \\
\hline $\mathrm{C}_{15} \mathrm{H}_{24} \mathrm{O}_{4}$ & 268.167459 & $\mathrm{C}_{19} \mathrm{H}_{30} \mathrm{O}_{5}$ & 338.209324 & $\mathrm{C}_{19} \mathrm{H}_{32} \mathrm{O}_{10}$ & 420.199547 \\
\hline $\mathrm{C}_{12} \mathrm{H}_{15} \mathrm{O}_{6} \mathrm{~N}_{1}$ & 269.089937 & $\mathrm{C}_{18} \mathrm{H}_{28} \mathrm{O}_{6}$ & 340.188589 & $\mathrm{C}_{16} \mathrm{H}_{22} \mathrm{O}_{11} \mathrm{~S}_{1}$ & 422.088282 \\
\hline $\mathrm{C}_{13} \mathrm{H}_{19} \mathrm{O}_{5} \mathrm{~N}_{1}$ & 269.126323 & $\mathrm{C}_{15} \mathrm{H}_{18} \mathrm{O}_{7} \mathrm{~S}_{1}$ & 342.077324 & $\mathrm{C}_{17} \mathrm{H}_{26} \mathrm{O}_{10} \mathrm{~S}_{1}$ & 422.124668 \\
\hline $\mathrm{C}_{12} \mathrm{H}_{14} \mathrm{O}_{7}$ & 270.073953 & $\mathrm{C}_{17} \mathrm{H}_{26} \mathrm{O}_{7}$ & 342.167853 & $\mathrm{C}_{17} \mathrm{H}_{26} \mathrm{O}_{12}$ & 422.142426 \\
\hline $\mathrm{C}_{13} \mathrm{H}_{18} \mathrm{O}_{6}$ & 270.110338 & $\mathrm{C}_{18} \mathrm{H}_{30} \mathrm{O}_{6}$ & 342.204239 & $\mathrm{C}_{23} \mathrm{H}_{34} \mathrm{O}_{7}$ & 422.230453 \\
\hline $\mathrm{C}_{14} \mathrm{H}_{22} \mathrm{O}_{5}$ & 270.146724 & $\mathrm{C}_{16} \mathrm{H}_{25} \mathrm{O}_{7} \mathrm{~N}_{1}$ & 343.163102 & $\mathrm{C}_{16} \mathrm{H}_{24} \mathrm{O}_{11} \mathrm{~S}_{1}$ & 424.103932 \\
\hline $\mathrm{C}_{12} \mathrm{H}_{17} \mathrm{O}_{6} \mathrm{~N}_{1}$ & 271.105587 & $\mathrm{C}_{14} \mathrm{H}_{16} \mathrm{O}_{8} \mathrm{~S}_{1}$ & 344.056588 & $\mathrm{C}_{23} \mathrm{H}_{36} \mathrm{O}_{7}$ & 424.246104 \\
\hline $\mathrm{C}_{11} \mathrm{H}_{12} \mathrm{O}_{8}$ & 272.053217 & $\mathrm{C}_{15} \mathrm{H}_{20} \mathrm{O}_{7} \mathrm{~S}_{1}$ & 344.092974 & $\mathrm{C}_{22} \mathrm{H}_{34} \mathrm{O}_{8}$ & 426.225368 \\
\hline $\mathrm{C}_{12} \mathrm{H}_{16} \mathrm{O}_{7}$ & 272.089603 & $\mathrm{C}_{14} \mathrm{H}_{20} \mathrm{O}_{8} \mathrm{~N}_{2}$ & 344.121966 & $\mathrm{C}_{20} \mathrm{H}_{28} \mathrm{O}_{8} \mathrm{~S}_{1}$ & 428.150489 \\
\hline $\mathrm{C}_{13} \mathrm{H}_{20} \mathrm{O}_{6}$ & 272.125988 & $\mathrm{C}_{16} \mathrm{H}_{24} \mathrm{O}_{8}$ & 344.147118 & $\mathrm{C}_{21} \mathrm{H}_{32} \mathrm{O}_{9}$ & 428.204633 \\
\hline $\mathrm{C}_{14} \mathrm{H}_{24} \mathrm{O}_{5}$ & 272.162374 & $\mathrm{C}_{17} \mathrm{H}_{28} \mathrm{O}_{7}$ & 344.183503 & $\mathrm{C}_{20} \mathrm{H}_{30} \mathrm{O}_{8} \mathrm{~S}_{1}$ & 430.166139 \\
\hline $\mathrm{C}_{11} \mathrm{H}_{14} \mathrm{O}_{8}$ & 274.068867 & $\mathrm{C}_{14} \mathrm{H}_{19} \mathrm{O}_{7} \mathrm{~N}_{1} \mathrm{~S}_{1}$ & 345.088223 & $\mathrm{C}_{20} \mathrm{H}_{30} \mathrm{O}_{10}$ & 430.183897 \\
\hline $\mathrm{C}_{12} \mathrm{H}_{18} \mathrm{O}_{7}$ & 274.105253 & $\mathrm{C}_{14} \mathrm{H}_{19} \mathrm{O}_{9} \mathrm{~N}_{1}$ & 345.105981 & $\mathrm{C}_{21} \mathrm{H}_{34} \mathrm{O}_{9}$ & 430.220283 \\
\hline $\mathrm{C}_{13} \mathrm{H}_{22} \mathrm{O}_{6}$ & 274.141638 & $\mathrm{C}_{15} \mathrm{H}_{23} \mathrm{O}_{8} \mathrm{~N}_{1}$ & 345.142367 & $\mathrm{C}_{18} \mathrm{H}_{25} \mathrm{O}_{9} \mathrm{~N}_{1} \mathrm{~S}_{1}$ & 431.125002 \\
\hline $\mathrm{C}_{11} \mathrm{H}_{16} \mathrm{O}_{6} \mathrm{~S}_{1}$ & 276.066759 & $\mathrm{C}_{14} \mathrm{H}_{18} \mathrm{O}_{8} \mathrm{~S}_{1}$ & 346.072238 & $\mathrm{C}_{19} \mathrm{H}_{29} \mathrm{O}_{10} \mathrm{~N}_{1}$ & 431.179146 \\
\hline $\mathrm{C}_{11} \mathrm{H}_{16} \mathrm{O}_{8}$ & 276.084518 & $\mathrm{C}_{14} \mathrm{H}_{18} \mathrm{O}_{10}$ & 346.089997 & $\mathrm{C}_{19} \mathrm{H}_{28} \mathrm{O}_{9} \mathrm{~S}_{1}$ & 432.145403 \\
\hline $\mathrm{C}_{12} \mathrm{H}_{20} \mathrm{O}_{7}$ & 276.120903 & $\mathrm{C}_{15} \mathrm{H}_{22} \mathrm{O}_{7} \mathrm{~S}_{1}$ & 346.108624 & $\mathrm{C}_{19} \mathrm{H}_{28} \mathrm{O}_{11}$ & 432.163162 \\
\hline $\mathrm{C}_{14} \mathrm{H}_{14} \mathrm{O}_{6}$ & 278.079038 & $\mathrm{C}_{15} \mathrm{H}_{22} \mathrm{O}_{9}$ & 346.126382 & $\mathrm{C}_{20} \mathrm{H}_{32} \mathrm{O}_{10}$ & 432.199547 \\
\hline $\mathrm{C}_{13} \mathrm{H}_{13} \mathrm{O}_{6} \mathrm{~N}_{1}$ & 279.074287 & $\mathrm{C}_{16} \mathrm{H}_{26} \mathrm{O}_{8}$ & 346.162768 & $\mathrm{C}_{18} \mathrm{H}_{27} \mathrm{O}_{11} \mathrm{~N}_{1}$ & 433.158411 \\
\hline $\mathrm{C}_{14} \mathrm{H}_{17} \mathrm{O}_{5} \mathrm{~N}_{1}$ & 279.110673 & $\mathrm{C}_{14} \mathrm{H}_{21} \mathrm{O}_{9} \mathrm{~N}_{1}$ & 347.121631 & $\mathrm{C}_{18} \mathrm{H}_{26} \mathrm{O}_{12}$ & 434.142426 \\
\hline $\mathrm{C}_{13} \mathrm{H}_{12} \mathrm{O}_{7}$ & 280.058303 & $\mathrm{C}_{13} \mathrm{H}_{16} \mathrm{O}_{9} \mathrm{~S}_{1}$ & 348.051503 & $\mathrm{C}_{19} \mathrm{H}_{30} \mathrm{O}_{9} \mathrm{~S}_{1}$ & 434.161053 \\
\hline $\mathrm{C}_{14} \mathrm{H}_{16} \mathrm{O}_{6}$ & 280.094688 & $\mathrm{C}_{14} \mathrm{H}_{20} \mathrm{O}_{8} \mathrm{~S}_{1}$ & 348.087888 & $\mathrm{C}_{19} \mathrm{H}_{30} \mathrm{O}_{11}$ & 434.178812 \\
\hline $\mathrm{C}_{16} \mathrm{H}_{24} \mathrm{O}_{4}$ & 280.167459 & $\mathrm{C}_{14} \mathrm{H}_{20} \mathrm{O}_{10}$ & 348.105647 & $\mathrm{C}_{17} \mathrm{H}_{24} \mathrm{O}_{11} \mathrm{~S}_{1}$ & 436.103932 \\
\hline $\mathrm{C}_{13} \mathrm{H}_{15} \mathrm{O}_{6} \mathrm{~N}_{1}$ & 281.089937 & $\mathrm{C}_{15} \mathrm{H}_{24} \mathrm{O}_{7} \mathrm{~S}_{1}$ & 348.124274 & $\mathrm{C}_{18} \mathrm{H}_{28} \mathrm{O}_{10} \mathrm{~S}_{1}$ & 436.140318 \\
\hline $\mathrm{C}_{14} \mathrm{H}_{19} \mathrm{O}_{5} \mathrm{~N}_{1}$ & 281.126323 & $\mathrm{C}_{15} \mathrm{H}_{24} \mathrm{O}_{9}$ & 348.142032 & $\mathrm{C}_{18} \mathrm{H}_{28} \mathrm{O}_{12}$ & 436.158076 \\
\hline $\mathrm{C}_{13} \mathrm{H}_{14} \mathrm{O}_{7}$ & 282.073953 & $\mathrm{C}_{20} \mathrm{H}_{28} \mathrm{O}_{5}$ & 348.193674 & $\mathrm{C}_{24} \mathrm{H}_{36} \mathrm{O}_{7}$ & 436.246104 \\
\hline $\mathrm{C}_{14} \mathrm{H}_{18} \mathrm{O}_{6}$ & 282.110338 & $\mathrm{C}_{13} \mathrm{H}_{18} \mathrm{O}_{9} \mathrm{~S}_{1}$ & 350.067153 & $\mathrm{C}_{16} \mathrm{H}_{22} \mathrm{O}_{12} \mathrm{~S}_{1}$ & 438.083197 \\
\hline $\mathrm{C}_{15} \mathrm{H}_{22} \mathrm{O}_{5}$ & 282.146724 & $\mathrm{C}_{14} \mathrm{H}_{22} \mathrm{O}_{8} \mathrm{~S}_{1}$ & 350.103538 & $\mathrm{C}_{23} \mathrm{H}_{36} \mathrm{O}_{8}$ & 440.241018 \\
\hline $\mathrm{C}_{13} \mathrm{H}_{17} \mathrm{O}_{6} \mathrm{~N}_{1}$ & 283.105587 & $\mathrm{C}_{14} \mathrm{H}_{22} \mathrm{O}_{10}$ & 350.121297 & $\mathrm{C}_{22} \mathrm{H}_{34} \mathrm{O}_{9}$ & 442.220283 \\
\hline $\mathrm{C}_{14} \mathrm{H}_{21} \mathrm{O}_{5} \mathrm{~N}_{1}$ & 283.141973 & $\mathrm{C}_{20} \mathrm{H}_{30} \mathrm{O}_{5}$ & 350.209324 & $\mathrm{C}_{20} \mathrm{H}_{29} \mathrm{O}_{10} \mathrm{~N}_{1}$ & 443.179146 \\
\hline $\mathrm{C}_{12} \mathrm{H}_{12} \mathrm{O}_{8}$ & 284.053217 & $\mathrm{C}_{15} \mathrm{H}_{12} \mathrm{O}_{10}$ & 352.043047 & $\mathrm{C}_{20} \mathrm{H}_{28} \mathrm{O}_{9} \mathrm{~S}_{1}$ & 444.145403 \\
\hline $\mathrm{C}_{13} \mathrm{H}_{16} \mathrm{O}_{7}$ & 284.089603 & $\mathrm{C}_{13} \mathrm{H}_{20} \mathrm{O}_{9} \mathrm{~S}_{1}$ & 352.082803 & $\mathrm{C}_{21} \mathrm{H}_{32} \mathrm{O}_{10}$ & 444.199547 \\
\hline $\mathrm{C}_{12} \mathrm{H}_{16} \mathrm{O}_{6} \mathrm{~N}_{2}$ & 284.100836 & $\mathrm{C}_{19} \mathrm{H}_{28} \mathrm{O}_{6}$ & 352.188589 & $\mathrm{C}_{22} \mathrm{H}_{36} \mathrm{O}_{9}$ & 444.235933 \\
\hline
\end{tabular}


Table A1. Continued.

\begin{tabular}{|c|c|c|c|c|c|}
\hline Elemental Formula & M & Elemental Formula & M & Elemental Formula & M \\
\hline $\mathrm{C}_{14} \mathrm{H}_{20} \mathrm{O}_{6}$ & 284.125988 & $\mathrm{C}_{19} \mathrm{H}_{30} \mathrm{O}_{6}$ & 354.204239 & $\mathrm{C}_{20} \mathrm{H}_{30} \mathrm{O}_{9} \mathrm{~S}_{1}$ & 446.161053 \\
\hline $\mathrm{C}_{15} \mathrm{H}_{24} \mathrm{O}_{5}$ & 284.162374 & $\mathrm{C}_{16} \mathrm{H}_{24} \mathrm{O}_{7} \mathrm{~N}_{2}$ & 356.158351 & $\mathrm{C}_{20} \mathrm{H}_{30} \mathrm{O}_{11}$ & 446.178812 \\
\hline $\mathrm{C}_{12} \mathrm{H}_{15} \mathrm{O}_{7} \mathrm{~N}_{1}$ & 285.084852 & $\mathrm{C}_{18} \mathrm{H}_{28} \mathrm{O}_{7}$ & 356.183503 & $\mathrm{C}_{21} \mathrm{H}_{34} \mathrm{O}_{10}$ & 446.215197 \\
\hline $\mathrm{C}_{13} \mathrm{H}_{19} \mathrm{O}_{6} \mathrm{~N}_{1}$ & 285.121237 & $\mathrm{C}_{16} \mathrm{H}_{23} \mathrm{O}_{8} \mathrm{~N}_{1}$ & 357.142367 & $\mathrm{C}_{19} \mathrm{H}_{28} \mathrm{O}_{10} \mathrm{~S}_{1}$ & 448.140318 \\
\hline $\mathrm{C}_{12} \mathrm{H}_{14} \mathrm{O}_{8}$ & 286.068867 & $\mathrm{C}_{15} \mathrm{H}_{18} \mathrm{O}_{8} \mathrm{~S}_{1}$ & 358.072238 & $\mathrm{C}_{19} \mathrm{H}_{28} \mathrm{O}_{12}$ & 448.158076 \\
\hline $\mathrm{C}_{13} \mathrm{H}_{18} \mathrm{O}_{7}$ & 286.105253 & $\mathrm{C}_{16} \mathrm{H}_{22} \mathrm{O}_{7} \mathrm{~S}_{1}$ & 358.108624 & $\mathrm{C}_{20} \mathrm{H}_{32} \mathrm{O}_{9} \mathrm{~S}_{1}$ & 448.176703 \\
\hline $\mathrm{C}_{14} \mathrm{H}_{22} \mathrm{O}_{6}$ & 286.141638 & $\mathrm{C}_{15} \mathrm{H}_{22} \mathrm{O}_{8} \mathrm{~N}_{2}$ & 358.137616 & $\mathrm{C}_{20} \mathrm{H}_{32} \mathrm{O}_{11}$ & 448.194462 \\
\hline $\mathrm{C}_{12} \mathrm{H}_{17} \mathrm{O}_{7} \mathrm{~N}_{1}$ & 287.100502 & $\mathrm{C}_{17} \mathrm{H}_{26} \mathrm{O}_{8}$ & 358.162768 & $\mathrm{C}_{18} \mathrm{H}_{26} \mathrm{O}_{11} \mathrm{~S}_{1}$ & 450.119582 \\
\hline $\mathrm{C}_{12} \mathrm{H}_{16} \mathrm{O}_{6} \mathrm{~S}_{1}$ & 288.066759 & $\mathrm{C}_{18} \mathrm{H}_{30} \mathrm{O}_{7}$ & 358.199153 & $\mathrm{C}_{18} \mathrm{H}_{26} \mathrm{O}_{13}$ & 450.137341 \\
\hline $\mathrm{C}_{12} \mathrm{H}_{16} \mathrm{O}_{8}$ & 288.084518 & $\mathrm{C}_{15} \mathrm{H}_{21} \mathrm{O}_{7} \mathrm{~N}_{1} \mathrm{~S}_{1}$ & 359.103873 & $\mathrm{C}_{19} \mathrm{H}_{30} \mathrm{O}_{12}$ & 450.173726 \\
\hline $\mathrm{C}_{13} \mathrm{H}_{20} \mathrm{O}_{7}$ & 288.120903 & $\mathrm{C}_{15} \mathrm{H}_{21} \mathrm{O}_{9} \mathrm{~N}_{1}$ & 359.121631 & $\mathrm{C}_{17} \mathrm{H}_{24} \mathrm{O}_{12} \mathrm{~S}_{1}$ & 452.098847 \\
\hline $\mathrm{C}_{14} \mathrm{H}_{24} \mathrm{O}_{6}$ & 288.157289 & $\mathrm{C}_{16} \mathrm{H}_{25} \mathrm{O}_{8} \mathrm{~N}_{1}$ & 359.158017 & $\mathrm{C}_{24} \mathrm{H}_{38} \mathrm{O}_{8}$ & 454.256668 \\
\hline $\mathrm{C}_{15} \mathrm{H}_{14} \mathrm{O}_{6}$ & 290.079038 & $\mathrm{C}_{14} \mathrm{H}_{16} \mathrm{O}_{9} \mathrm{~S}_{1}$ & 360.051503 & $\mathrm{C}_{23} \mathrm{H}_{36} \mathrm{O}_{9}$ & 456.235933 \\
\hline $\mathrm{C}_{12} \mathrm{H}_{18} \mathrm{O}_{6} \mathrm{~S}_{1}$ & 290.082409 & $\mathrm{C}_{15} \mathrm{H}_{20} \mathrm{O}_{8} \mathrm{~S}_{1}$ & 360.087888 & $\mathrm{C}_{21} \mathrm{H}_{31} \mathrm{O}_{10} \mathrm{~N}_{1}$ & 457.194796 \\
\hline $\mathrm{C}_{12} \mathrm{H}_{18} \mathrm{O}_{8}$ & 290.100168 & $\mathrm{C}_{16} \mathrm{H}_{24} \mathrm{O}_{7} \mathrm{~S}_{1}$ & 360.124274 & $\mathrm{C}_{19} \mathrm{H}_{26} \mathrm{O}_{11} \mathrm{~N}_{2}$ & 458.15366 \\
\hline $\mathrm{C}_{13} \mathrm{H}_{22} \mathrm{O}_{7}$ & 290.136553 & $\mathrm{C}_{16} \mathrm{H}_{24} \mathrm{O}_{9}$ & 360.142032 & $\mathrm{C}_{22} \mathrm{H}_{34} \mathrm{O}_{10}$ & 458.215197 \\
\hline $\mathrm{C}_{14} \mathrm{H}_{13} \mathrm{O}_{6} \mathrm{~N}_{1}$ & 291.074287 & $\mathrm{C}_{17} \mathrm{H}_{28} \mathrm{O}_{8}$ & 360.178418 & $\mathrm{C}_{20} \mathrm{H}_{29} \mathrm{O}_{11} \mathrm{~N}_{1}$ & 459.174061 \\
\hline $\mathrm{C}_{14} \mathrm{H}_{12} \mathrm{O}_{7}$ & 292.058303 & $\mathrm{C}_{17} \mathrm{H}_{15} \mathrm{O}_{8} \mathrm{~N}_{1}$ & 361.079767 & $\mathrm{C}_{21} \mathrm{H}_{32} \mathrm{O}_{9} \mathrm{~S}_{1}$ & 460.176703 \\
\hline $\mathrm{C}_{11} \mathrm{H}_{16} \mathrm{O}_{7} \mathrm{~S}_{1}$ & 292.061674 & $\mathrm{C}_{15} \mathrm{H}_{23} \mathrm{O}_{7} \mathrm{~N}_{1} \mathrm{~S}_{1}$ & 361.119523 & $\mathrm{C}_{21} \mathrm{H}_{32} \mathrm{O}_{11}$ & 460.194462 \\
\hline $\mathrm{C}_{12} \mathrm{H}_{20} \mathrm{O}_{6} \mathrm{~S}_{1}$ & 292.098059 & $\mathrm{C}_{15} \mathrm{H}_{23} \mathrm{O}_{9} \mathrm{~N}_{1}$ & 361.137281 & $\mathrm{C}_{19} \mathrm{H}_{27} \mathrm{O}_{12} \mathrm{~N}_{1}$ & 461.153325 \\
\hline $\mathrm{C}_{14} \mathrm{H}_{16} \mathrm{O}_{5} \mathrm{~N}_{2}$ & 292.105922 & $\mathrm{C}_{14} \mathrm{H}_{18} \mathrm{O}_{9} \mathrm{~S}_{1}$ & 362.067153 & $\mathrm{C}_{20} \mathrm{H}_{30} \mathrm{O}_{10} \mathrm{~S}_{1}$ & 462.155968 \\
\hline $\mathrm{C}_{15} \mathrm{H}_{20} \mathrm{O}_{4} \mathrm{~N}_{2}$ & 292.142307 & $\mathrm{C}_{15} \mathrm{H}_{22} \mathrm{O}_{8} \mathrm{~S}_{1}$ & 362.103538 & $\mathrm{C}_{20} \mathrm{H}_{30} \mathrm{O}_{12}$ & 462.173726 \\
\hline $\mathrm{C}_{14} \mathrm{H}_{15} \mathrm{O}_{6} \mathrm{~N}_{1}$ & 293.089937 & $\mathrm{C}_{15} \mathrm{H}_{22} \mathrm{O}_{10}$ & 362.121297 & $\mathrm{C}_{21} \mathrm{H}_{34} \mathrm{O}_{11}$ & 462.210112 \\
\hline $\mathrm{C}_{15} \mathrm{H}_{19} \mathrm{O}_{5} \mathrm{~N}_{1}$ & 293.126323 & $\mathrm{C}_{16} \mathrm{H}_{26} \mathrm{O}_{7} \mathrm{~S}_{1}$ & 362.139924 & $\mathrm{C}_{19} \mathrm{H}_{28} \mathrm{O}_{11} \mathrm{~S}_{1}$ & 464.135232 \\
\hline $\mathrm{C}_{14} \mathrm{H}_{14} \mathrm{O}_{7}$ & 294.073953 & $\mathrm{C}_{16} \mathrm{H}_{26} \mathrm{O}_{9}$ & 362.157682 & $\mathrm{C}_{19} \mathrm{H}_{28} \mathrm{O}_{13}$ & 464.152991 \\
\hline $\mathrm{C}_{13} \mathrm{H}_{13} \mathrm{O}_{7} \mathrm{~N}_{1}$ & 295.069202 & $\mathrm{C}_{14} \mathrm{H}_{21} \mathrm{O}_{8} \mathrm{~N}_{1} \mathrm{~S}_{1}$ & 363.098787 & $\mathrm{C}_{20} \mathrm{H}_{32} \mathrm{O}_{12}$ & 464.189377 \\
\hline $\mathrm{C}_{14} \mathrm{H}_{17} \mathrm{O}_{6} \mathrm{~N}_{1}$ & 295.105587 & $\mathrm{C}_{13} \mathrm{H}_{16} \mathrm{O}_{10} \mathrm{~S}_{1}$ & 364.046417 & $\mathrm{C}_{18} \mathrm{H}_{26} \mathrm{O}_{12} \mathrm{~S}_{1}$ & 466.114497 \\
\hline $\mathrm{C}_{13} \mathrm{H}_{12} \mathrm{O}_{8}$ & 296.053217 & $\mathrm{C}_{14} \mathrm{H}_{20} \mathrm{O}_{9} \mathrm{~S}_{1}$ & 364.082803 & $\mathrm{C}_{24} \mathrm{H}_{38} \mathrm{O}_{9}$ & 470.251583 \\
\hline $\mathrm{C}_{14} \mathrm{H}_{16} \mathrm{O}_{7}$ & 296.089603 & $\mathrm{C}_{15} \mathrm{H}_{24} \mathrm{O}_{8} \mathrm{~S}_{1}$ & 364.119188 & $\mathrm{C}_{22} \mathrm{H}_{32} \mathrm{O}_{9} \mathrm{~S}_{1}$ & 472.176703 \\
\hline $\mathrm{C}_{11} \mathrm{H}_{20} \mathrm{O}_{7} \mathrm{~S}_{1}$ & 296.092974 & $\mathrm{C}_{15} \mathrm{H}_{24} \mathrm{O}_{10}$ & 364.136947 & $\mathrm{C}_{23} \mathrm{H}_{36} \mathrm{O}_{10}$ & 472.230847 \\
\hline $\mathrm{C}_{15} \mathrm{H}_{20} \mathrm{O}_{6}$ & 296.125988 & $\mathrm{C}_{14} \mathrm{H}_{22} \mathrm{O}_{9} \mathrm{~S}_{1}$ & 366.098453 & $\mathrm{C}_{21} \mathrm{H}_{31} \mathrm{O}_{11} \mathrm{~N}_{1}$ & 473.189711 \\
\hline $\mathrm{C}_{16} \mathrm{H}_{24} \mathrm{O}_{5}$ & 296.162374 & $\mathrm{C}_{20} \mathrm{H}_{30} \mathrm{O}_{6}$ & 366.204239 & $\mathrm{C}_{22} \mathrm{H}_{34} \mathrm{O}_{11}$ & 474.210112 \\
\hline $\mathrm{C}_{13} \mathrm{H}_{15} \mathrm{O}_{7} \mathrm{~N}_{1}$ & 297.084852 & $\mathrm{C}_{13} \mathrm{H}_{20} \mathrm{O}_{10} \mathrm{~S}_{1}$ & 368.077718 & $\mathrm{C}_{21} \mathrm{H}_{32} \mathrm{O}_{10} \mathrm{~S}_{1}$ & 476.171618 \\
\hline $\mathrm{C}_{14} \mathrm{H}_{19} \mathrm{O}_{6} \mathrm{~N}_{1}$ & 297.121237 & $\mathrm{C}_{20} \mathrm{H}_{32} \mathrm{O}_{6}$ & 368.219889 & $\mathrm{C}_{21} \mathrm{H}_{32} \mathrm{O}_{12}$ & 476.189377 \\
\hline $\mathrm{C}_{13} \mathrm{H}_{14} \mathrm{O}_{8}$ & 298.068867 & $\mathrm{C}_{19} \mathrm{H}_{30} \mathrm{O}_{7}$ & 370.199153 & $\mathrm{C}_{20} \mathrm{H}_{30} \mathrm{O}_{11} \mathrm{~S}_{1}$ & 478.150883 \\
\hline $\mathrm{C}_{14} \mathrm{H}_{18} \mathrm{O}_{7}$ & 298.105253 & $\mathrm{C}_{16} \mathrm{H}_{21} \mathrm{O}_{9} \mathrm{~N}_{1}$ & 371.121631 & $\mathrm{C}_{20} \mathrm{H}_{30} \mathrm{O}_{13}$ & 478.168641 \\
\hline $\mathrm{C}_{13} \mathrm{H}_{18} \mathrm{O}_{6} \mathrm{~N}_{2}$ & 298.116486 & $\mathrm{C}_{17} \mathrm{H}_{25} \mathrm{O}_{8} \mathrm{~N}_{1}$ & 371.158017 & $\mathrm{C}_{19} \mathrm{H}_{28} \mathrm{O}_{12} \mathrm{~S}_{1}$ & 480.130147 \\
\hline $\mathrm{C}_{15} \mathrm{H}_{22} \mathrm{O}_{6}$ & 298.141638 & $\mathrm{C}_{17} \mathrm{H}_{24} \mathrm{O}_{7} \mathrm{~S}_{1}$ & 372.124274 & $\mathrm{C}_{25} \mathrm{H}_{38} \mathrm{O}_{9}$ & 482.251583 \\
\hline $\mathrm{C}_{16} \mathrm{H}_{26} \mathrm{O}_{5}$ & 298.178024 & $\mathrm{C}_{16} \mathrm{H}_{24} \mathrm{O}_{8} \mathrm{~N}_{2}$ & 372.153266 & $\mathrm{C}_{24} \mathrm{H}_{38} \mathrm{O}_{10}$ & 486.246497 \\
\hline $\mathrm{C}_{13} \mathrm{H}_{17} \mathrm{O}_{7} \mathrm{~N}_{1}$ & 299.100502 & $\mathrm{C}_{18} \mathrm{H}_{28} \mathrm{O}_{8}$ & 372.178418 & $\mathrm{C}_{22} \mathrm{H}_{32} \mathrm{O}_{10} \mathrm{~S}_{1}$ & 488.171618 \\
\hline $\mathrm{C}_{14} \mathrm{H}_{21} \mathrm{O}_{6} \mathrm{~N}_{1}$ & 299.136887 & $\mathrm{C}_{19} \mathrm{H}_{32} \mathrm{O}_{7}$ & 372.214803 & $\mathrm{C}_{23} \mathrm{H}_{36} \mathrm{O}_{11}$ & 488.225762 \\
\hline $\mathrm{C}_{13} \mathrm{H}_{16} \mathrm{O}_{8}$ & 300.084518 & $\mathrm{C}_{15} \mathrm{H}_{19} \mathrm{O}_{8} \mathrm{~N}_{1} \mathrm{~S}_{1}$ & 373.083137 & $\mathrm{C}_{22} \mathrm{H}_{34} \mathrm{O}_{12}$ & 490.205027 \\
\hline $\mathrm{C}_{14} \mathrm{H}_{20} \mathrm{O}_{7}$ & 300.120903 & $\mathrm{C}_{16} \mathrm{H}_{23} \mathrm{O}_{9} \mathrm{~N}_{1}$ & 373.137281 & $\mathrm{C}_{21} \mathrm{H}_{32} \mathrm{O}_{11} \mathrm{~S}_{1}$ & 492.166533 \\
\hline $\mathrm{C}_{13} \mathrm{H}_{20} \mathrm{O}_{6} \mathrm{~N}_{2}$ & 300.132136 & $\mathrm{C}_{15} \mathrm{H}_{18} \mathrm{O}_{9} \mathrm{~S}_{1}$ & 374.067153 & $\mathrm{C}_{21} \mathrm{H}_{32} \mathrm{O}_{13}$ & 492.184291 \\
\hline $\mathrm{C}_{15} \mathrm{H}_{24} \mathrm{O}_{6}$ & 300.157289 & $\mathrm{C}_{16} \mathrm{H}_{22} \mathrm{O}_{8} \mathrm{~S}_{1}$ & 374.103538 & $\mathrm{C}_{27} \mathrm{H}_{40} \mathrm{O}_{8}$ & 492.272318 \\
\hline $\mathrm{C}_{12} \mathrm{H}_{15} \mathrm{O}_{8} \mathrm{~N}_{1}$ & 301.079767 & $\mathrm{C}_{16} \mathrm{H}_{22} \mathrm{O}_{10}$ & 374.121297 & $\mathrm{C}_{20} \mathrm{H}_{30} \mathrm{O}_{12} \mathrm{~S}_{1}$ & 494.145797 \\
\hline $\mathrm{C}_{13} \mathrm{H}_{19} \mathrm{O}_{7} \mathrm{~N}_{1}$ & 301.116152 & $\mathrm{C}_{17} \mathrm{H}_{26} \mathrm{O}_{7} \mathrm{~S}_{1}$ & 374.139924 & $\mathrm{C}_{26} \mathrm{H}_{40} \mathrm{O}_{9}$ & 496.267233 \\
\hline $\mathrm{C}_{12} \mathrm{H}_{14} \mathrm{O}_{9}$ & 302.063782 & $\mathrm{C}_{17} \mathrm{H}_{26} \mathrm{O}_{9}$ & 374.157682 & $\mathrm{C}_{25} \mathrm{H}_{38} \mathrm{O}_{10}$ & 498.246497 \\
\hline $\mathrm{C}_{13} \mathrm{H}_{18} \mathrm{O}_{6} \mathrm{~S}_{1}$ & 302.082409 & $\mathrm{C}_{18} \mathrm{H}_{30} \mathrm{O}_{8}$ & 374.194068 & $\mathrm{C}_{24} \mathrm{H}_{36} \mathrm{O}_{11}$ & 500.225762 \\
\hline $\mathrm{C}_{13} \mathrm{H}_{18} \mathrm{O}_{8}$ & 302.100168 & $\mathrm{C}_{15} \mathrm{H}_{21} \mathrm{O}_{8} \mathrm{~N}_{1} \mathrm{~S}_{1}$ & 375.098787 & $\mathrm{C}_{23} \mathrm{H}_{34} \mathrm{O}_{10} \mathrm{~S}_{1}$ & 502.187268 \\
\hline $\mathrm{C}_{14} \mathrm{H}_{22} \mathrm{O}_{7}$ & 302.136553 & $\mathrm{C}_{15} \mathrm{H}_{21} \mathrm{O}_{10} \mathrm{~N}_{1}$ & 375.116546 & $\mathrm{C}_{24} \mathrm{H}_{38} \mathrm{O}_{11}$ & 502.241412 \\
\hline $\mathrm{C}_{15} \mathrm{H}_{26} \mathrm{O}_{6}$ & 302.172939 & $\mathrm{C}_{16} \mathrm{H}_{25} \mathrm{O}_{9} \mathrm{~N}_{1}$ & 375.152931 & $\mathrm{C}_{23} \mathrm{H}_{36} \mathrm{O}_{12}$ & 504.220677 \\
\hline $\mathrm{C}_{15} \mathrm{H}_{12} \mathrm{O}_{7}$ & 304.058303 & $\mathrm{C}_{14} \mathrm{H}_{16} \mathrm{O}_{10} \mathrm{~S}_{1}$ & 376.046417 & $\mathrm{C}_{22} \mathrm{H}_{34} \mathrm{O}_{13}$ & 506.199941 \\
\hline $\mathrm{C}_{12} \mathrm{H}_{16} \mathrm{O}_{7} \mathrm{~S}_{1}$ & 304.061674 & $\mathrm{C}_{15} \mathrm{H}_{20} \mathrm{O}_{9} \mathrm{~S}_{1}$ & 376.082803 & $\mathrm{C}_{19} \mathrm{H}_{26} \mathrm{O}_{14} \mathrm{~S}_{1}$ & 510.104326 \\
\hline $\mathrm{C}_{12} \mathrm{H}_{16} \mathrm{O}_{9}$ & 304.079432 & $\mathrm{C}_{15} \mathrm{H}_{20} \mathrm{O}_{11}$ & 376.100562 & $\mathrm{C}_{26} \mathrm{H}_{40} \mathrm{O}_{10}$ & 512.262148 \\
\hline $\mathrm{C}_{13} \mathrm{H}_{20} \mathrm{O}_{6} \mathrm{~S}_{1}$ & 304.098059 & $\mathrm{C}_{16} \mathrm{H}_{24} \mathrm{O}_{8} \mathrm{~S}_{1}$ & 376.119188 & $\mathrm{C}_{25} \mathrm{H}_{38} \mathrm{O}_{11}$ & 514.241412 \\
\hline $\mathrm{C}_{13} \mathrm{H}_{20} \mathrm{O}_{8}$ & 304.115818 & $\mathrm{C}_{16} \mathrm{H}_{24} \mathrm{O}_{10}$ & 376.136947 & $\mathrm{C}_{24} \mathrm{H}_{36} \mathrm{O}_{12}$ & 516.220677 \\
\hline
\end{tabular}


Table A1. Continued.

\begin{tabular}{lrllll}
\hline Elemental Formula & $M$ & Elemental Formula & $M$ & Elemental Formula & $M$ \\
\hline $\mathrm{C}_{14} \mathrm{H}_{24} \mathrm{O}_{7}$ & 304.152203 & $\mathrm{C}_{17} \mathrm{H}_{28} \mathrm{O}_{9}$ & 376.173333 & $\mathrm{C}_{23} \mathrm{H}_{34} \mathrm{O}_{11} \mathrm{~S}_{1}$ & 518.182183 \\
$\mathrm{C}_{15} \mathrm{H}_{14} \mathrm{O}_{7}$ & 306.073953 & $\mathrm{C}_{15} \mathrm{H}_{23} \mathrm{O}_{8} \mathrm{~N}_{1} \mathrm{~S}_{1}$ & 377.114437 & $\mathrm{C}_{22} \mathrm{H}_{32} \mathrm{O}_{12} \mathrm{~S}_{1}$ & 520.161447 \\
$\mathrm{C}_{12} \mathrm{H}_{18} \mathrm{O}_{7} \mathrm{~S}_{1}$ & 306.077324 & $\mathrm{C}_{14} \mathrm{H}_{18} \mathrm{O}_{10} \mathrm{~S}_{1}$ & 378.062068 & $\mathrm{C}_{26} \mathrm{H}_{40} \mathrm{O}_{11}$ & 528.257062 \\
$\mathrm{C}_{12} \mathrm{H}_{18} \mathrm{O}_{9}$ & 306.095082 & $\mathrm{C}_{15} \mathrm{H}_{22} \mathrm{O}_{9} \mathrm{~S}_{1}$ & 378.098453 & $\mathrm{C}_{25} \mathrm{H}_{38} \mathrm{O}_{12}$ & 530.236327 \\
$\mathrm{C}_{13} \mathrm{H}_{22} \mathrm{O}_{6} \mathrm{~S}_{1}$ & 306.113709 & $\mathrm{C}_{15} \mathrm{H}_{22} \mathrm{O}_{11}$ & 378.116212 & $\mathrm{C}_{24} \mathrm{H}_{36} \mathrm{O}_{13}$ & 532.215591 \\
$\mathrm{C}_{13} \mathrm{H}_{22} \mathrm{O}_{8}$ & 306.131468 & $\mathrm{C}_{16} \mathrm{H}_{26} \mathrm{O}_{8} \mathrm{~S}_{1}$ & 378.134839 & $\mathrm{C}_{27} \mathrm{H}_{42} \mathrm{O}_{11}$ & 542.272712 \\
$\mathrm{C}_{18} \mathrm{H}_{26} \mathrm{O}_{4}$ & 306.183109 & $\mathrm{C}_{16} \mathrm{H}_{26} \mathrm{O}_{10}$ & 378.152597 & $\mathrm{C}_{26} \mathrm{H}_{40} \mathrm{O}_{12}$ & 544.251977 \\
$\mathrm{C}_{14} \mathrm{H}_{13} \mathrm{O}_{7} \mathrm{~N}_{1}$ & 307.069202 & $\mathrm{C}_{14} \mathrm{H}_{20} \mathrm{O}_{10} \mathrm{~S}_{1}$ & 380.077718 & $\mathrm{C}_{25} \mathrm{H}_{38} \mathrm{O}_{13}$ & 546.231241 \\
$\mathrm{C}_{14} \mathrm{H}_{12} \mathrm{O}_{8}$ & 308.053217 & $\mathrm{C}_{15} \mathrm{H}_{24} \mathrm{O}_{9} \mathrm{~S}_{1}$ & 380.114103 & $\mathrm{C}_{24} \mathrm{H}_{36} \mathrm{O}_{14}$ & 548.210506 \\
$\mathrm{C}_{11} \mathrm{H}_{16} \mathrm{O}_{8} \mathrm{~S}_{1}$ & 308.056588 & $\mathrm{C}_{21} \mathrm{H}_{32} \mathrm{O}_{6}$ & 380.219889 & $\mathrm{C}_{26} \mathrm{H}_{40} \mathrm{O}_{13}$ & 560.246891 \\
$\mathrm{C}_{12} \mathrm{H}_{20} \mathrm{O}_{7} \mathrm{~S}_{1}$ & 308.092974 & $\mathrm{C}_{14} \mathrm{H}_{22} \mathrm{O}_{10} \mathrm{~S}_{1}$ & 382.093368 & $\mathrm{C}_{25} \mathrm{H}_{36} \mathrm{O}_{13} \mathrm{~S}_{1}$ & 576.187662 \\
$\mathrm{C}_{14} \mathrm{H}_{16} \mathrm{O}_{6} \mathrm{~N}_{2}$ & 308.100836 & $\mathrm{C}_{18} \mathrm{H}_{24} \mathrm{O}_{7} \mathrm{~S}_{1}$ & 384.124274 & $\mathrm{C}_{46} \mathrm{H}_{24}$ & 576.187801 \\
$\mathrm{C}_{17} \mathrm{H}_{24} \mathrm{O}_{5}$ & 308.162374 & $\mathrm{C}_{20} \mathrm{H}_{32} \mathrm{O}_{7}$ & 384.214803 & $\mathrm{C}_{24} \mathrm{H}_{34} \mathrm{O}_{14} \mathrm{~S}_{1}$ & 578.166927 \\
\hline
\end{tabular}

Table A2. NEG molecular formulas: complete list of mass peaks and assigned molecular formulas that showed a highly significant negative correlation $(p<0.01)$ with SPE-DOM $\Delta^{14} \mathrm{C}$.

\begin{tabular}{|c|c|c|c|c|c|}
\hline Elemental Formula & M & Elemental Formula & M & Elemental Formula & M \\
\hline $\mathrm{C}_{17} \mathrm{H}_{16} \mathrm{O}_{6}$ & 316.094688 & $\mathrm{C}_{22} \mathrm{H}_{23} \mathrm{O}_{9} \mathrm{~N}_{1}$ & 445.137281 & $\mathrm{C}_{23} \mathrm{H}_{25} \mathrm{O}_{12} \mathrm{~N}_{1}$ & 507.137675 \\
\hline $\mathrm{C}_{18} \mathrm{H}_{20} \mathrm{O}_{5}$ & 316.131074 & $\mathrm{C}_{21} \mathrm{H}_{18} \mathrm{O}_{11}$ & 446.084911 & $\mathrm{C}_{24} \mathrm{H}_{29} \mathrm{O}_{11} \mathrm{~N}_{1}$ & 507.174061 \\
\hline $\mathrm{C}_{17} \mathrm{H}_{18} \mathrm{O}_{6}$ & 318.110338 & $\mathrm{C}_{22} \mathrm{H}_{22} \mathrm{O}_{10}$ & 446.121297 & $\mathrm{C}_{23} \mathrm{H}_{24} \mathrm{O}_{13}$ & 508.121691 \\
\hline $\mathrm{C}_{17} \mathrm{H}_{20} \mathrm{O}_{6}$ & 320.125988 & $\mathrm{C}_{21} \mathrm{H}_{22} \mathrm{O}_{9} \mathrm{~N}_{2}$ & 446.13253 & $\mathrm{C}_{22} \mathrm{H}_{24} \mathrm{O}_{12} \mathrm{~N}_{2}$ & 508.132924 \\
\hline $\mathrm{C}_{18} \mathrm{H}_{18} \mathrm{O}_{6}$ & 330.110338 & $\mathrm{C}_{23} \mathrm{H}_{26} \mathrm{O}_{9}$ & 446.157682 & $\mathrm{C}_{24} \mathrm{H}_{28} \mathrm{O}_{12}$ & 508.158076 \\
\hline $\mathrm{C}_{19} \mathrm{H}_{22} \mathrm{O}_{5}$ & 330.146724 & $\mathrm{C}_{24} \mathrm{H}_{30} \mathrm{O}_{8}$ & 446.194068 & $\mathrm{C}_{25} \mathrm{H}_{32} \mathrm{O}_{11}$ & 508.194462 \\
\hline $\mathrm{C}_{17} \mathrm{H}_{16} \mathrm{O}_{7}$ & 332.089603 & $\mathrm{C}_{21} \mathrm{H}_{21} \mathrm{O}_{10} \mathrm{~N}_{1}$ & 447.116546 & $\mathrm{C}_{26} \mathrm{H}_{36} \mathrm{O}_{10}$ & 508.230847 \\
\hline $\mathrm{C}_{18} \mathrm{H}_{20} \mathrm{O}_{6}$ & 332.125988 & $\mathrm{C}_{22} \mathrm{H}_{25} \mathrm{O}_{9} \mathrm{~N}_{1}$ & 447.152931 & $\mathrm{C}_{22} \mathrm{H}_{23} \mathrm{O}_{13} \mathrm{~N}_{1}$ & 509.11694 \\
\hline $\mathrm{C}_{17} \mathrm{H}_{18} \mathrm{O}_{7}$ & 334.105253 & $\mathrm{C}_{21} \mathrm{H}_{20} \mathrm{O}_{11}$ & 448.100562 & $\mathrm{C}_{23} \mathrm{H}_{27} \mathrm{O}_{12} \mathrm{~N}_{1}$ & 509.153325 \\
\hline $\mathrm{C}_{18} \mathrm{H}_{22} \mathrm{O}_{6}$ & 334.141638 & $\mathrm{C}_{20} \mathrm{H}_{20} \mathrm{O}_{10} \mathrm{~N}_{2}$ & 448.111795 & $\mathrm{C}_{24} \mathrm{H}_{31} \mathrm{O}_{11} \mathrm{~N}_{1}$ & 509.189711 \\
\hline $\mathrm{C}_{17} \mathrm{H}_{20} \mathrm{O}_{7}$ & 336.120903 & $\mathrm{C}_{22} \mathrm{H}_{24} \mathrm{O}_{10}$ & 448.136947 & $\mathrm{C}_{22} \mathrm{H}_{22} \mathrm{O}_{14}$ & 510.100955 \\
\hline $\mathrm{C}_{17} \mathrm{H}_{24} \mathrm{O}_{5} \mathrm{~N}_{2}$ & 336.168522 & $\mathrm{C}_{21} \mathrm{H}_{24} \mathrm{O}_{9} \mathrm{~N}_{2}$ & 448.14818 & $\mathrm{C}_{23} \mathrm{H}_{26} \mathrm{O}_{13}$ & 510.137341 \\
\hline $\mathrm{C}_{19} \mathrm{H}_{20} \mathrm{O}_{6}$ & 344.125988 & $\mathrm{C}_{23} \mathrm{H}_{28} \mathrm{O}_{9}$ & 448.173333 & $\mathrm{C}_{22} \mathrm{H}_{26} \mathrm{O}_{12} \mathrm{~N}_{2}$ & 510.148574 \\
\hline $\mathrm{C}_{20} \mathrm{H}_{24} \mathrm{O}_{5}$ & 344.162374 & $\mathrm{C}_{20} \mathrm{H}_{19} \mathrm{O}_{11} \mathrm{~N}_{1}$ & 449.09581 & $\mathrm{C}_{24} \mathrm{H}_{30} \mathrm{O}_{12}$ & 510.173726 \\
\hline $\mathrm{C}_{18} \mathrm{H}_{18} \mathrm{O}_{7}$ & 346.105253 & $\mathrm{C}_{21} \mathrm{H}_{23} \mathrm{O}_{10} \mathrm{~N}_{1}$ & 449.132196 & $\mathrm{C}_{23} \mathrm{H}_{30} \mathrm{O}_{11} \mathrm{~N}_{2}$ & 510.18496 \\
\hline $\mathrm{C}_{19} \mathrm{H}_{22} \mathrm{O}_{6}$ & 346.141638 & $\mathrm{C}_{22} \mathrm{H}_{27} \mathrm{O}_{9} \mathrm{~N}_{1}$ & 449.168582 & $\mathrm{C}_{25} \mathrm{H}_{34} \mathrm{O}_{11}$ & 510.210112 \\
\hline $\mathrm{C}_{18} \mathrm{H}_{21} \mathrm{O}_{6} \mathrm{~N}_{1}$ & 347.136887 & $\mathrm{C}_{20} \mathrm{H}_{18} \mathrm{O}_{12}$ & 450.079826 & $\mathrm{C}_{22} \mathrm{H}_{25} \mathrm{O}_{13} \mathrm{~N}_{1}$ & 511.13259 \\
\hline $\mathrm{C}_{17} \mathrm{H}_{16} \mathrm{O}_{8}$ & 348.084518 & $\mathrm{C}_{19} \mathrm{H}_{18} \mathrm{O}_{11} \mathrm{~N}_{2}$ & 450.091059 & $\mathrm{C}_{23} \mathrm{H}_{29} \mathrm{O}_{12} \mathrm{~N}_{1}$ & 511.168975 \\
\hline $\mathrm{C}_{18} \mathrm{H}_{20} \mathrm{O}_{7}$ & 348.120903 & $\mathrm{C}_{21} \mathrm{H}_{22} \mathrm{O}_{11}$ & 450.116212 & $\mathrm{C}_{22} \mathrm{H}_{24} \mathrm{O}_{14}$ & 512.116605 \\
\hline $\mathrm{C}_{17} \mathrm{H}_{19} \mathrm{O}_{7} \mathrm{~N}_{1}$ & 349.116152 & $\mathrm{C}_{20} \mathrm{H}_{22} \mathrm{O}_{10} \mathrm{~N}_{2}$ & 450.127445 & $\mathrm{C}_{21} \mathrm{H}_{24} \mathrm{O}_{13} \mathrm{~N}_{2}$ & 512.127839 \\
\hline $\mathrm{C}_{18} \mathrm{H}_{23} \mathrm{O}_{6} \mathrm{~N}_{1}$ & 349.152538 & $\mathrm{C}_{22} \mathrm{H}_{26} \mathrm{O}_{10}$ & 450.152597 & $\mathrm{C}_{23} \mathrm{H}_{28} \mathrm{O}_{13}$ & 512.152991 \\
\hline $\mathrm{C}_{17} \mathrm{H}_{18} \mathrm{O}_{8}$ & 350.100168 & $\mathrm{C}_{21} \mathrm{H}_{26} \mathrm{O}_{9} \mathrm{~N}_{2}$ & 450.16383 & $\mathrm{C}_{22} \mathrm{H}_{28} \mathrm{O}_{12} \mathrm{~N}_{2}$ & 512.164224 \\
\hline $\mathrm{C}_{18} \mathrm{H}_{22} \mathrm{O}_{7}$ & 350.136553 & $\mathrm{C}_{23} \mathrm{H}_{30} \mathrm{O}_{9}$ & 450.188983 & $\mathrm{C}_{24} \mathrm{H}_{32} \mathrm{O}_{12}$ & 512.189377 \\
\hline $\mathrm{C}_{17} \mathrm{H}_{20} \mathrm{O}_{8}$ & 352.115818 & $\mathrm{C}_{20} \mathrm{H}_{21} \mathrm{O}_{11} \mathrm{~N}_{1}$ & 451.111461 & $\mathrm{C}_{22} \mathrm{H}_{27} \mathrm{O}_{13} \mathrm{~N}_{1}$ & 513.14824 \\
\hline $\mathrm{C}_{16} \mathrm{H}_{18} \mathrm{O}_{9}$ & 354.095082 & $\mathrm{C}_{21} \mathrm{H}_{25} \mathrm{O}_{10} \mathrm{~N}_{1}$ & 451.147846 & $\mathrm{C}_{22} \mathrm{H}_{26} \mathrm{O}_{14}$ & 514.132256 \\
\hline $\mathrm{C}_{17} \mathrm{H}_{22} \mathrm{O}_{8}$ & 354.131468 & $\mathrm{C}_{22} \mathrm{H}_{29} \mathrm{O}_{9} \mathrm{~N}_{1}$ & 451.184232 & $\mathrm{C}_{23} \mathrm{H}_{30} \mathrm{O}_{13}$ & 514.168641 \\
\hline $\mathrm{C}_{19} \mathrm{H}_{18} \mathrm{O}_{7}$ & 358.105253 & $\mathrm{C}_{20} \mathrm{H}_{20} \mathrm{O}_{12}$ & 452.095476 & $\mathrm{C}_{24} \mathrm{H}_{34} \mathrm{O}_{12}$ & 514.205027 \\
\hline $\mathrm{C}_{20} \mathrm{H}_{22} \mathrm{O}_{6}$ & 358.141638 & $\mathrm{C}_{19} \mathrm{H}_{20} \mathrm{O}_{11} \mathrm{~N}_{2}$ & 452.10671 & $\mathrm{C}_{25} \mathrm{H}_{24} \mathrm{O}_{12}$ & 516.126776 \\
\hline $\mathrm{C}_{18} \mathrm{H}_{16} \mathrm{O}_{8}$ & 360.084518 & $\mathrm{C}_{21} \mathrm{H}_{24} \mathrm{O}_{11}$ & 452.131862 & $\mathrm{C}_{22} \mathrm{H}_{28} \mathrm{O}_{14}$ & 516.147906 \\
\hline $\mathrm{C}_{19} \mathrm{H}_{20} \mathrm{O}_{7}$ & 360.120903 & $\mathrm{C}_{20} \mathrm{H}_{24} \mathrm{O}_{10} \mathrm{~N}_{2}$ & 452.143095 & $\mathrm{C}_{26} \mathrm{H}_{28} \mathrm{O}_{11}$ & 516.163162 \\
\hline $\mathrm{C}_{20} \mathrm{H}_{24} \mathrm{O}_{6}$ & 360.157289 & $\mathrm{C}_{22} \mathrm{H}_{28} \mathrm{O}_{10}$ & 452.168247 & $\mathrm{C}_{27} \mathrm{H}_{32} \mathrm{O}_{10}$ & 516.199547 \\
\hline $\mathrm{C}_{18} \mathrm{H}_{19} \mathrm{O}_{7} \mathrm{~N}_{1}$ & 361.116152 & $\mathrm{C}_{23} \mathrm{H}_{32} \mathrm{O}_{9}$ & 452.204633 & $\mathrm{C}_{28} \mathrm{H}_{36} \mathrm{O}_{9}$ & 516.235933 \\
\hline $\mathrm{C}_{19} \mathrm{H}_{23} \mathrm{O}_{6} \mathrm{~N}_{1}$ & 361.152538 & $\mathrm{C}_{20} \mathrm{H}_{23} \mathrm{O}_{11} \mathrm{~N}_{1}$ & 453.127111 & $\mathrm{C}_{24} \mathrm{H}_{22} \mathrm{O}_{13}$ & 518.106041 \\
\hline $\mathrm{C}_{18} \mathrm{H}_{18} \mathrm{O}_{8}$ & 362.100168 & $\mathrm{C}_{21} \mathrm{H}_{27} \mathrm{O}_{10} \mathrm{~N}_{1}$ & 453.163496 & $\mathrm{C}_{25} \mathrm{H}_{26} \mathrm{O}_{12}$ & 518.142426 \\
\hline
\end{tabular}


Table A2. Continued.

\begin{tabular}{|c|c|c|c|c|c|}
\hline Elemental Formula & M & Elemental Formula & M & Elemental Formula & M \\
\hline $\mathrm{C}_{19} \mathrm{H}_{22} \mathrm{O}_{7}$ & 362.136553 & $\mathrm{C}_{20} \mathrm{H}_{22} \mathrm{O}_{12}$ & 454.111126 & $\mathrm{C}_{24} \mathrm{H}_{26} \mathrm{O}_{11} \mathrm{~N}_{2}$ & 518.15366 \\
\hline $\mathrm{C}_{18} \mathrm{H}_{21} \mathrm{O}_{7} \mathrm{~N}_{1}$ & 363.131802 & $\mathrm{C}_{19} \mathrm{H}_{22} \mathrm{O}_{11} \mathrm{~N}_{2}$ & 454.12236 & $\mathrm{C}_{26} \mathrm{H}_{30} \mathrm{O}_{11}$ & 518.178812 \\
\hline $\mathrm{C}_{17} \mathrm{H}_{16} \mathrm{O}_{9}$ & 364.079432 & $\mathrm{C}_{21} \mathrm{H}_{26} \mathrm{O}_{11}$ & 454.147512 & $\mathrm{C}_{27} \mathrm{H}_{34} \mathrm{O}_{10}$ & 518.215197 \\
\hline $\mathrm{C}_{18} \mathrm{H}_{20} \mathrm{O}_{8}$ & 364.115818 & $\mathrm{C}_{20} \mathrm{H}_{26} \mathrm{O}_{10} \mathrm{~N}_{2}$ & 454.158745 & $\mathrm{C}_{24} \mathrm{H}_{25} \mathrm{O}_{12} \mathrm{~N}_{1}$ & 519.137675 \\
\hline $\mathrm{C}_{19} \mathrm{H}_{24} \mathrm{O}_{7}$ & 364.152203 & $\mathrm{C}_{22} \mathrm{H}_{30} \mathrm{O}_{10}$ & 454.183897 & $\mathrm{C}_{25} \mathrm{H}_{29} \mathrm{O}_{11} \mathrm{~N}_{1}$ & 519.174061 \\
\hline $\mathrm{C}_{17} \mathrm{H}_{19} \mathrm{O}_{8} \mathrm{~N}_{1}$ & 365.111067 & $\mathrm{C}_{19} \mathrm{H}_{21} \mathrm{O}_{12} \mathrm{~N}_{1}$ & 455.106375 & $\mathrm{C}_{24} \mathrm{H}_{24} \mathrm{O}_{13}$ & 520.121691 \\
\hline $\mathrm{C}_{18} \mathrm{H}_{23} \mathrm{O}_{7} \mathrm{~N}_{1}$ & 365.147452 & $\mathrm{C}_{20} \mathrm{H}_{25} \mathrm{O}_{11} \mathrm{~N}_{1}$ & 455.142761 & $\mathrm{C}_{23} \mathrm{H}_{24} \mathrm{O}_{12} \mathrm{~N}_{2}$ & 520.132924 \\
\hline $\mathrm{C}_{17} \mathrm{H}_{18} \mathrm{O}_{9}$ & 366.095082 & $\mathrm{C}_{20} \mathrm{H}_{24} \mathrm{O}_{12}$ & 456.126776 & $\mathrm{C}_{25} \mathrm{H}_{28} \mathrm{O}_{12}$ & 520.158076 \\
\hline $\mathrm{C}_{18} \mathrm{H}_{22} \mathrm{O}_{8}$ & 366.131468 & $\mathrm{C}_{21} \mathrm{H}_{28} \mathrm{O}_{11}$ & 456.163162 & $\mathrm{C}_{24} \mathrm{H}_{28} \mathrm{O}_{11} \mathrm{~N}_{2}$ & 520.16931 \\
\hline $\mathrm{C}_{17} \mathrm{H}_{21} \mathrm{O}_{8} \mathrm{~N}_{1}$ & 367.126717 & $\mathrm{C}_{20} \mathrm{H}_{27} \mathrm{O}_{11} \mathrm{~N}_{1}$ & 457.158411 & $\mathrm{C}_{26} \mathrm{H}_{32} \mathrm{O}_{11}$ & 520.194462 \\
\hline $\mathrm{C}_{17} \mathrm{H}_{20} \mathrm{O}_{9}$ & 368.110732 & $\mathrm{C}_{19} \mathrm{H}_{22} \mathrm{O}_{13}$ & 458.106041 & $\mathrm{C}_{27} \mathrm{H}_{36} \mathrm{O}_{10}$ & 520.230847 \\
\hline $\mathrm{C}_{17} \mathrm{H}_{22} \mathrm{O}_{9}$ & 370.126382 & $\mathrm{C}_{23} \mathrm{H}_{22} \mathrm{O}_{10}$ & 458.121297 & $\mathrm{C}_{24} \mathrm{H}_{27} \mathrm{O}_{12} \mathrm{~N}_{1}$ & 521.153325 \\
\hline $\mathrm{C}_{14} \mathrm{H}_{16} \mathrm{O}_{8} \mathrm{~N}_{2} \mathrm{~S}_{1}$ & 372.062736 & $\mathrm{C}_{20} \mathrm{H}_{26} \mathrm{O}_{12}$ & 458.142426 & $\mathrm{C}_{25} \mathrm{H}_{31} \mathrm{O}_{11} \mathrm{~N}_{1}$ & 521.189711 \\
\hline $\mathrm{C}_{20} \mathrm{H}_{20} \mathrm{O}_{7}$ & 372.120903 & $\mathrm{C}_{24} \mathrm{H}_{26} \mathrm{O}_{9}$ & 458.157682 & $\mathrm{C}_{23} \mathrm{H}_{22} \mathrm{O}_{14}$ & 522.100955 \\
\hline $\mathrm{C}_{19} \mathrm{H}_{18} \mathrm{O}_{8}$ & 374.100168 & $\mathrm{C}_{25} \mathrm{H}_{30} \mathrm{O}_{8}$ & 458.194068 & $\mathrm{C}_{24} \mathrm{H}_{26} \mathrm{O}_{13}$ & 522.137341 \\
\hline $\mathrm{C}_{20} \mathrm{H}_{22} \mathrm{O}_{7}$ & 374.136553 & $\mathrm{C}_{22} \mathrm{H}_{20} \mathrm{O}_{11}$ & 460.100562 & $\mathrm{C}_{23} \mathrm{H}_{26} \mathrm{O}_{12} \mathrm{~N}_{2}$ & 522.148574 \\
\hline $\mathrm{C}_{19} \mathrm{H}_{21} \mathrm{O}_{7} \mathrm{~N}_{1}$ & 375.131802 & $\mathrm{C}_{19} \mathrm{H}_{24} \mathrm{O}_{13}$ & 460.121691 & $\mathrm{C}_{25} \mathrm{H}_{30} \mathrm{O}_{12}$ & 522.173726 \\
\hline $\mathrm{C}_{18} \mathrm{H}_{16} \mathrm{O}_{9}$ & 376.079432 & $\mathrm{C}_{23} \mathrm{H}_{24} \mathrm{O}_{10}$ & 460.136947 & $\mathrm{C}_{24} \mathrm{H}_{30} \mathrm{O}_{11} \mathrm{~N}_{2}$ & 522.18496 \\
\hline $\mathrm{C}_{19} \mathrm{H}_{20} \mathrm{O}_{8}$ & 376.115818 & $\mathrm{C}_{24} \mathrm{H}_{28} \mathrm{O}_{9}$ & 460.173333 & $\mathrm{C}_{26} \mathrm{H}_{34} \mathrm{O}_{11}$ & 522.210112 \\
\hline $\mathrm{C}_{20} \mathrm{H}_{24} \mathrm{O}_{7}$ & 376.152203 & $\mathrm{C}_{22} \mathrm{H}_{23} \mathrm{O}_{10} \mathrm{~N}_{1}$ & 461.132196 & $\mathrm{C}_{23} \mathrm{H}_{25} \mathrm{O}_{13} \mathrm{~N}_{1}$ & 523.13259 \\
\hline $\mathrm{C}_{18} \mathrm{H}_{19} \mathrm{O}_{8} \mathrm{~N}_{1}$ & 377.111067 & $\mathrm{C}_{23} \mathrm{H}_{27} \mathrm{O}_{9} \mathrm{~N}_{1}$ & 461.168582 & $\mathrm{C}_{24} \mathrm{H}_{29} \mathrm{O}_{12} \mathrm{~N}_{1}$ & 523.168975 \\
\hline $\mathrm{C}_{19} \mathrm{H}_{23} \mathrm{O}_{7} \mathrm{~N}_{1}$ & 377.147452 & $\mathrm{C}_{21} \mathrm{H}_{18} \mathrm{O}_{12}$ & 462.079826 & $\mathrm{C}_{23} \mathrm{H}_{24} \mathrm{O}_{14}$ & 524.116605 \\
\hline $\mathrm{C}_{18} \mathrm{H}_{18} \mathrm{O}_{9}$ & 378.095082 & $\mathrm{C}_{22} \mathrm{H}_{22} \mathrm{O}_{11}$ & 462.116212 & $\mathrm{C}_{24} \mathrm{H}_{28} \mathrm{O}_{13}$ & 524.152991 \\
\hline $\mathrm{C}_{19} \mathrm{H}_{22} \mathrm{O}_{8}$ & 378.131468 & $\mathrm{C}_{21} \mathrm{H}_{22} \mathrm{O}_{10} \mathrm{~N}_{2}$ & 462.127445 & $\mathrm{C}_{23} \mathrm{H}_{28} \mathrm{O}_{12} \mathrm{~N}_{2}$ & 524.164224 \\
\hline $\mathrm{C}_{17} \mathrm{H}_{17} \mathrm{O}_{9} \mathrm{~N}_{1}$ & 379.090331 & $\mathrm{C}_{23} \mathrm{H}_{26} \mathrm{O}_{10}$ & 462.152597 & $\mathrm{C}_{25} \mathrm{H}_{32} \mathrm{O}_{12}$ & 524.189377 \\
\hline $\mathrm{C}_{18} \mathrm{H}_{21} \mathrm{O}_{8} \mathrm{~N}_{1}$ & 379.126717 & $\mathrm{C}_{22} \mathrm{H}_{26} \mathrm{O}_{9} \mathrm{~N}_{2}$ & 462.16383 & $\mathrm{C}_{26} \mathrm{H}_{36} \mathrm{O}_{11}$ & 524.225762 \\
\hline $\mathrm{C}_{17} \mathrm{H}_{16} \mathrm{O}_{10}$ & 380.074347 & $\mathrm{C}_{24} \mathrm{H}_{30} \mathrm{O}_{9}$ & 462.188983 & $\mathrm{C}_{22} \mathrm{H}_{23} \mathrm{O}_{14} \mathrm{~N}_{1}$ & 525.111854 \\
\hline $\mathrm{C}_{18} \mathrm{H}_{20} \mathrm{O}_{9}$ & 380.110732 & $\mathrm{C}_{21} \mathrm{H}_{21} \mathrm{O}_{11} \mathrm{~N}_{1}$ & 463.111461 & $\mathrm{C}_{23} \mathrm{H}_{27} \mathrm{O}_{13} \mathrm{~N}_{1}$ & 525.14824 \\
\hline $\mathrm{C}_{17} \mathrm{H}_{20} \mathrm{O}_{8} \mathrm{~N}_{2}$ & 380.121966 & $\mathrm{C}_{22} \mathrm{H}_{25} \mathrm{O}_{10} \mathrm{~N}_{1}$ & 463.147846 & $\mathrm{C}_{24} \mathrm{H}_{31} \mathrm{O}_{12} \mathrm{~N}_{1}$ & 525.184625 \\
\hline $\mathrm{C}_{17} \mathrm{H}_{19} \mathrm{O}_{9} \mathrm{~N}_{1}$ & 381.105981 & $\mathrm{C}_{23} \mathrm{H}_{29} \mathrm{O}_{9} \mathrm{~N}_{1}$ & 463.184232 & $\mathrm{C}_{23} \mathrm{H}_{26} \mathrm{O}_{14}$ & 526.132256 \\
\hline $\mathrm{C}_{17} \mathrm{H}_{18} \mathrm{O}_{10}$ & 382.089997 & $\mathrm{C}_{21} \mathrm{H}_{20} \mathrm{O}_{12}$ & 464.095476 & $\mathrm{C}_{22} \mathrm{H}_{26} \mathrm{O}_{13} \mathrm{~N}_{2}$ & 526.143489 \\
\hline $\mathrm{C}_{18} \mathrm{H}_{22} \mathrm{O}_{9}$ & 382.126382 & $\mathrm{C}_{20} \mathrm{H}_{20} \mathrm{O}_{11} \mathrm{~N}_{2}$ & 464.10671 & $\mathrm{C}_{24} \mathrm{H}_{30} \mathrm{O}_{13}$ & 526.168641 \\
\hline $\mathrm{C}_{17} \mathrm{H}_{21} \mathrm{O}_{9} \mathrm{~N}_{1}$ & 383.121631 & $\mathrm{C}_{22} \mathrm{H}_{24} \mathrm{O}_{11}$ & 464.131862 & $\mathrm{C}_{25} \mathrm{H}_{34} \mathrm{O}_{12}$ & 526.205027 \\
\hline $\mathrm{C}_{17} \mathrm{H}_{20} \mathrm{O}_{10}$ & 384.105647 & $\mathrm{C}_{21} \mathrm{H}_{24} \mathrm{O}_{10} \mathrm{~N}_{2}$ & 464.143095 & $\mathrm{C}_{22} \mathrm{H}_{25} \mathrm{O}_{14} \mathrm{~N}_{1}$ & 527.127505 \\
\hline $\mathrm{C}_{20} \mathrm{H}_{18} \mathrm{O}_{8}$ & 386.100168 & $\mathrm{C}_{23} \mathrm{H}_{28} \mathrm{O}_{10}$ & 464.168247 & $\mathrm{C}_{22} \mathrm{H}_{24} \mathrm{O}_{15}$ & 528.11152 \\
\hline $\mathrm{C}_{21} \mathrm{H}_{22} \mathrm{O}_{7}$ & 386.136553 & $\mathrm{C}_{22} \mathrm{H}_{28} \mathrm{O}_{9} \mathrm{~N}_{2}$ & 464.179481 & $\mathrm{C}_{23} \mathrm{H}_{28} \mathrm{O}_{14}$ & 528.147906 \\
\hline $\mathrm{C}_{20} \mathrm{H}_{20} \mathrm{O}_{8}$ & 388.115818 & $\mathrm{C}_{24} \mathrm{H}_{32} \mathrm{O}_{9}$ & 464.204633 & $\mathrm{C}_{24} \mathrm{H}_{32} \mathrm{O}_{13}$ & 528.184291 \\
\hline $\mathrm{C}_{21} \mathrm{H}_{24} \mathrm{O}_{7}$ & 388.152203 & $\mathrm{C}_{21} \mathrm{H}_{23} \mathrm{O}_{11} \mathrm{~N}_{1}$ & 465.127111 & $\mathrm{C}_{26} \mathrm{H}_{26} \mathrm{O}_{12}$ & 530.142426 \\
\hline $\mathrm{C}_{19} \mathrm{H}_{19} \mathrm{O}_{8} \mathrm{~N}_{1}$ & 389.111067 & $\mathrm{C}_{22} \mathrm{H}_{27} \mathrm{O}_{10} \mathrm{~N}_{1}$ & 465.163496 & $\mathrm{C}_{23} \mathrm{H}_{30} \mathrm{O}_{14}$ & 530.163556 \\
\hline $\mathrm{C}_{20} \mathrm{H}_{23} \mathrm{O}_{7} \mathrm{~N}_{1}$ & 389.147452 & $\mathrm{C}_{21} \mathrm{H}_{22} \mathrm{O}_{12}$ & 466.111126 & $\mathrm{C}_{27} \mathrm{H}_{30} \mathrm{O}_{11}$ & 530.178812 \\
\hline $\mathrm{C}_{19} \mathrm{H}_{18} \mathrm{O}_{9}$ & 390.095082 & $\mathrm{C}_{20} \mathrm{H}_{22} \mathrm{O}_{11} \mathrm{~N}_{2}$ & 466.12236 & $\mathrm{C}_{28} \mathrm{H}_{34} \mathrm{O}_{10}$ & 530.215197 \\
\hline $\mathrm{C}_{20} \mathrm{H}_{22} \mathrm{O}_{8}$ & 390.131468 & $\mathrm{C}_{22} \mathrm{H}_{26} \mathrm{O}_{11}$ & 466.147512 & $\mathrm{C}_{25} \mathrm{H}_{24} \mathrm{O}_{13}$ & 532.121691 \\
\hline $\mathrm{C}_{19} \mathrm{H}_{21} \mathrm{O}_{8} \mathrm{~N}_{1}$ & 391.126717 & $\mathrm{C}_{21} \mathrm{H}_{26} \mathrm{O}_{10} \mathrm{~N}_{2}$ & 466.158745 & $\mathrm{C}_{26} \mathrm{H}_{28} \mathrm{O}_{12}$ & 532.158076 \\
\hline $\mathrm{C}_{19} \mathrm{H}_{20} \mathrm{O}_{9}$ & 392.110732 & $\mathrm{C}_{23} \mathrm{H}_{30} \mathrm{O}_{10}$ & 466.183897 & $\mathrm{C}_{27} \mathrm{H}_{32} \mathrm{O}_{11}$ & 532.194462 \\
\hline $\mathrm{C}_{18} \mathrm{H}_{20} \mathrm{O}_{8} \mathrm{~N}_{2}$ & 392.121966 & $\mathrm{C}_{20} \mathrm{H}_{21} \mathrm{O}_{12} \mathrm{~N}_{1}$ & 467.106375 & $\mathrm{C}_{28} \mathrm{H}_{36} \mathrm{O}_{10}$ & 532.230847 \\
\hline $\mathrm{C}_{20} \mathrm{H}_{24} \mathrm{O}_{8}$ & 392.147118 & $\mathrm{C}_{21} \mathrm{H}_{25} \mathrm{O}_{11} \mathrm{~N}_{1}$ & 467.142761 & $\mathrm{C}_{25} \mathrm{H}_{27} \mathrm{O}_{12} \mathrm{~N}_{1}$ & 533.153325 \\
\hline $\mathrm{C}_{19} \mathrm{H}_{24} \mathrm{O}_{7} \mathrm{~N}_{2}$ & 392.158351 & $\mathrm{C}_{22} \mathrm{H}_{29} \mathrm{O}_{10} \mathrm{~N}_{1}$ & 467.179146 & $\mathrm{C}_{26} \mathrm{H}_{31} \mathrm{O}_{11} \mathrm{~N}_{1}$ & 533.189711 \\
\hline $\mathrm{C}_{18} \mathrm{H}_{19} \mathrm{O}_{9} \mathrm{~N}_{1}$ & 393.105981 & $\mathrm{C}_{20} \mathrm{H}_{20} \mathrm{O}_{13}$ & 468.090391 & $\mathrm{C}_{24} \mathrm{H}_{22} \mathrm{O}_{14}$ & 534.100955 \\
\hline $\mathrm{C}_{19} \mathrm{H}_{23} \mathrm{O}_{8} \mathrm{~N}_{1}$ & 393.142367 & $\mathrm{C}_{21} \mathrm{H}_{24} \mathrm{O}_{12}$ & 468.126776 & $\mathrm{C}_{25} \mathrm{H}_{26} \mathrm{O}_{13}$ & 534.137341 \\
\hline $\mathrm{C}_{20} \mathrm{H}_{27} \mathrm{O}_{7} \mathrm{~N}_{1}$ & 393.178752 & $\mathrm{C}_{20} \mathrm{H}_{24} \mathrm{O}_{11} \mathrm{~N}_{2}$ & 468.13801 & $\mathrm{C}_{26} \mathrm{H}_{30} \mathrm{O}_{12}$ & 534.173726 \\
\hline $\mathrm{C}_{18} \mathrm{H}_{18} \mathrm{O}_{10}$ & 394.089997 & $\mathrm{C}_{22} \mathrm{H}_{28} \mathrm{O}_{11}$ & 468.163162 & $\mathrm{C}_{25} \mathrm{H}_{30} \mathrm{O}_{11} \mathrm{~N}_{2}$ & 534.18496 \\
\hline $\mathrm{C}_{19} \mathrm{H}_{22} \mathrm{O}_{9}$ & 394.126382 & $\mathrm{C}_{21} \mathrm{H}_{28} \mathrm{O}_{10} \mathrm{~N}_{2}$ & 468.174395 & $\mathrm{C}_{27} \mathrm{H}_{34} \mathrm{O}_{11}$ & 534.210112 \\
\hline $\mathrm{C}_{18} \mathrm{H}_{22} \mathrm{O}_{8} \mathrm{~N}_{2}$ & 394.137616 & $\mathrm{C}_{23} \mathrm{H}_{32} \mathrm{O}_{10}$ & 468.199547 & $\mathrm{C}_{28} \mathrm{H}_{38} \mathrm{O}_{10}$ & 534.246497 \\
\hline $\mathrm{C}_{18} \mathrm{H}_{21} \mathrm{O}_{9} \mathrm{~N}_{1}$ & 395.121631 & $\mathrm{C}_{20} \mathrm{H}_{23} \mathrm{O}_{12} \mathrm{~N}_{1}$ & 469.122025 & $\mathrm{C}_{25} \mathrm{H}_{29} \mathrm{O}_{12} \mathrm{~N}_{1}$ & 535.168975 \\
\hline
\end{tabular}


Table A2. Continued.

\begin{tabular}{|c|c|c|c|c|c|}
\hline Elemental Formula & M & Elemental Formula & M & Elemental Formula & M \\
\hline $\mathrm{C}_{18} \mathrm{H}_{20} \mathrm{O}_{10}$ & 396.105647 & $\mathrm{C}_{21} \mathrm{H}_{27} \mathrm{O}_{11} \mathrm{~N}_{1}$ & 469.158411 & $\mathrm{C}_{26} \mathrm{H}_{33} \mathrm{O}_{11} \mathrm{~N}_{1}$ & 535.205361 \\
\hline $\mathrm{C}_{17} \mathrm{H}_{20} \mathrm{O}_{9} \mathrm{~N}_{2}$ & 396.11688 & $\mathrm{C}_{20} \mathrm{H}_{22} \mathrm{O}_{13}$ & 470.106041 & $\mathrm{C}_{23} \mathrm{H}_{20} \mathrm{O}_{15}$ & 536.08022 \\
\hline $\mathrm{C}_{19} \mathrm{H}_{24} \mathrm{O}_{9}$ & 396.142032 & $\mathrm{C}_{21} \mathrm{H}_{26} \mathrm{O}_{12}$ & 470.142426 & $\mathrm{C}_{24} \mathrm{H}_{24} \mathrm{O}_{14}$ & 536.116605 \\
\hline $\mathrm{C}_{17} \mathrm{H}_{19} \mathrm{O}_{10} \mathrm{~N}_{1}$ & 397.100896 & $\mathrm{C}_{20} \mathrm{H}_{26} \mathrm{O}_{11} \mathrm{~N}_{2}$ & 470.15366 & $\mathrm{C}_{23} \mathrm{H}_{24} \mathrm{O}_{13} \mathrm{~N}_{2}$ & 536.127839 \\
\hline $\mathrm{C}_{18} \mathrm{H}_{23} \mathrm{O}_{9} \mathrm{~N}_{1}$ & 397.137281 & $\mathrm{C}_{22} \mathrm{H}_{30} \mathrm{O}_{11}$ & 470.178812 & $\mathrm{C}_{25} \mathrm{H}_{28} \mathrm{O}_{13}$ & 536.152991 \\
\hline $\mathrm{C}_{17} \mathrm{H}_{18} \mathrm{O}_{11}$ & 398.084911 & $\mathrm{C}_{20} \mathrm{H}_{25} \mathrm{O}_{12} \mathrm{~N}_{1}$ & 471.137675 & $\mathrm{C}_{24} \mathrm{H}_{28} \mathrm{O}_{12} \mathrm{~N}_{2}$ & 536.164224 \\
\hline $\mathrm{C}_{18} \mathrm{H}_{22} \mathrm{O}_{10}$ & 398.121297 & $\mathrm{C}_{20} \mathrm{H}_{24} \mathrm{O}_{13}$ & 472.121691 & $\mathrm{C}_{26} \mathrm{H}_{32} \mathrm{O}_{12}$ & 536.189377 \\
\hline $\mathrm{C}_{17} \mathrm{H}_{20} \mathrm{O}_{11}$ & 400.100562 & $\mathrm{C}_{24} \mathrm{H}_{24} \mathrm{O}_{10}$ & 472.136947 & $\mathrm{C}_{27} \mathrm{H}_{36} \mathrm{O}_{11}$ & 536.225762 \\
\hline $\mathrm{C}_{21} \mathrm{H}_{20} \mathrm{O}_{8}$ & 400.115818 & $\mathrm{C}_{21} \mathrm{H}_{28} \mathrm{O}_{12}$ & 472.158076 & $\mathrm{C}_{24} \mathrm{H}_{27} \mathrm{O}_{13} \mathrm{~N}_{1}$ & 537.14824 \\
\hline $\mathrm{C}_{18} \mathrm{H}_{24} \mathrm{O}_{10}$ & 400.136947 & $\mathrm{C}_{25} \mathrm{H}_{28} \mathrm{O}_{9}$ & 472.173333 & $\mathrm{C}_{25} \mathrm{H}_{31} \mathrm{O}_{12} \mathrm{~N}_{1}$ & 537.184625 \\
\hline $\mathrm{C}_{22} \mathrm{H}_{24} \mathrm{O}_{7}$ & 400.152203 & $\mathrm{C}_{26} \mathrm{H}_{32} \mathrm{O}_{8}$ & 472.209718 & $\mathrm{C}_{23} \mathrm{H}_{22} \mathrm{O}_{15}$ & 538.09587 \\
\hline $\mathrm{C}_{20} \mathrm{H}_{18} \mathrm{O}_{9}$ & 402.095082 & $\mathrm{C}_{23} \mathrm{H}_{22} \mathrm{O}_{11}$ & 474.116212 & $\mathrm{C}_{24} \mathrm{H}_{26} \mathrm{O}_{14}$ & 538.132256 \\
\hline $\mathrm{C}_{21} \mathrm{H}_{22} \mathrm{O}_{8}$ & 402.131468 & $\mathrm{C}_{24} \mathrm{H}_{26} \mathrm{O}_{10}$ & 474.152597 & $\mathrm{C}_{23} \mathrm{H}_{26} \mathrm{O}_{13} \mathrm{~N}_{2}$ & 538.143489 \\
\hline $\mathrm{C}_{22} \mathrm{H}_{26} \mathrm{O}_{7}$ & 402.167853 & $\mathrm{C}_{25} \mathrm{H}_{30} \mathrm{O}_{9}$ & 474.188983 & $\mathrm{C}_{25} \mathrm{H}_{30} \mathrm{O}_{13}$ & 538.168641 \\
\hline $\mathrm{C}_{20} \mathrm{H}_{21} \mathrm{O}_{8} \mathrm{~N}_{1}$ & 403.126717 & $\mathrm{C}_{23} \mathrm{H}_{25} \mathrm{O}_{10} \mathrm{~N}_{1}$ & 475.147846 & $\mathrm{C}_{24} \mathrm{H}_{30} \mathrm{O}_{12} \mathrm{~N}_{2}$ & 538.179874 \\
\hline $\mathrm{C}_{20} \mathrm{H}_{20} \mathrm{O}_{9}$ & 404.110732 & $\mathrm{C}_{22} \mathrm{H}_{20} \mathrm{O}_{12}$ & 476.095476 & $\mathrm{C}_{26} \mathrm{H}_{34} \mathrm{O}_{12}$ & 538.205027 \\
\hline $\mathrm{C}_{19} \mathrm{H}_{20} \mathrm{O}_{8} \mathrm{~N}_{2}$ & 404.121966 & $\mathrm{C}_{21} \mathrm{H}_{20} \mathrm{O}_{11} \mathrm{~N}_{2}$ & 476.10671 & $\mathrm{C}_{27} \mathrm{H}_{38} \mathrm{O}_{11}$ & 538.241412 \\
\hline $\mathrm{C}_{21} \mathrm{H}_{24} \mathrm{O}_{8}$ & 404.147118 & $\mathrm{C}_{23} \mathrm{H}_{24} \mathrm{O}_{11}$ & 476.131862 & $\mathrm{C}_{23} \mathrm{H}_{25} \mathrm{O}_{14} \mathrm{~N}_{1}$ & 539.127505 \\
\hline $\mathrm{C}_{20} \mathrm{H}_{24} \mathrm{O}_{7} \mathrm{~N}_{2}$ & 404.158351 & $\mathrm{C}_{22} \mathrm{H}_{24} \mathrm{O}_{10} \mathrm{~N}_{2}$ & 476.143095 & $\mathrm{C}_{24} \mathrm{H}_{29} \mathrm{O}_{13} \mathrm{~N}_{1}$ & 539.16389 \\
\hline $\mathrm{C}_{19} \mathrm{H}_{19} \mathrm{O}_{9} \mathrm{~N}_{1}$ & 405.105981 & $\mathrm{C}_{24} \mathrm{H}_{28} \mathrm{O}_{10}$ & 476.168247 & $\mathrm{C}_{25} \mathrm{H}_{33} \mathrm{O}_{12} \mathrm{~N}_{1}$ & 539.200276 \\
\hline $\mathrm{C}_{20} \mathrm{H}_{23} \mathrm{O}_{8} \mathrm{~N}_{1}$ & 405.142367 & $\mathrm{C}_{23} \mathrm{H}_{28} \mathrm{O}_{9} \mathrm{~N}_{2}$ & 476.179481 & $\mathrm{C}_{23} \mathrm{H}_{24} \mathrm{O}_{15}$ & 540.11152 \\
\hline $\mathrm{C}_{19} \mathrm{H}_{18} \mathrm{O}_{10}$ & 406.089997 & $\mathrm{C}_{25} \mathrm{H}_{32} \mathrm{O}_{9}$ & 476.204633 & $\mathrm{C}_{24} \mathrm{H}_{28} \mathrm{O}_{14}$ & 540.147906 \\
\hline $\mathrm{C}_{18} \mathrm{H}_{18} \mathrm{O}_{9} \mathrm{~N}_{2}$ & 406.10123 & $\mathrm{C}_{22} \mathrm{H}_{23} \mathrm{O}_{11} \mathrm{~N}_{1}$ & 477.127111 & $\mathrm{C}_{25} \mathrm{H}_{32} \mathrm{O}_{13}$ & 540.184291 \\
\hline $\mathrm{C}_{20} \mathrm{H}_{22} \mathrm{O}_{9}$ & 406.126382 & $\mathrm{C}_{23} \mathrm{H}_{27} \mathrm{O}_{10} \mathrm{~N}_{1}$ & 477.163496 & $\mathrm{C}_{26} \mathrm{H}_{36} \mathrm{O}_{12}$ & 540.220677 \\
\hline $\mathrm{C}_{19} \mathrm{H}_{22} \mathrm{O}_{8} \mathrm{~N}_{2}$ & 406.137616 & $\mathrm{C}_{24} \mathrm{H}_{31} \mathrm{O}_{9} \mathrm{~N}_{1}$ & 477.199882 & $\mathrm{C}_{23} \mathrm{H}_{27} \mathrm{O}_{14} \mathrm{~N}_{1}$ & 541.143155 \\
\hline $\mathrm{C}_{21} \mathrm{H}_{26} \mathrm{O}_{8}$ & 406.162768 & $\mathrm{C}_{21} \mathrm{H}_{18} \mathrm{O}_{13}$ & 478.074741 & $\mathrm{C}_{24} \mathrm{H}_{30} \mathrm{O}_{14}$ & 542.163556 \\
\hline $\mathrm{C}_{18} \mathrm{H}_{17} \mathrm{O}_{10} \mathrm{~N}_{1}$ & 407.085246 & $\mathrm{C}_{22} \mathrm{H}_{22} \mathrm{O}_{12}$ & 478.111126 & $\mathrm{C}_{25} \mathrm{H}_{34} \mathrm{O}_{13}$ & 542.199941 \\
\hline $\mathrm{C}_{19} \mathrm{H}_{21} \mathrm{O}_{9} \mathrm{~N}_{1}$ & 407.121631 & $\mathrm{C}_{21} \mathrm{H}_{22} \mathrm{O}_{11} \mathrm{~N}_{2}$ & 478.12236 & $\mathrm{C}_{23} \mathrm{H}_{28} \mathrm{O}_{15}$ & 544.14282 \\
\hline $\mathrm{C}_{20} \mathrm{H}_{25} \mathrm{O}_{8} \mathrm{~N}_{1}$ & 407.158017 & $\mathrm{C}_{23} \mathrm{H}_{26} \mathrm{O}_{11}$ & 478.147512 & $\mathrm{C}_{27} \mathrm{H}_{28} \mathrm{O}_{12}$ & 544.158076 \\
\hline $\mathrm{C}_{19} \mathrm{H}_{20} \mathrm{O}_{10}$ & 408.105647 & $\mathrm{C}_{22} \mathrm{H}_{26} \mathrm{O}_{10} \mathrm{~N}_{2}$ & 478.158745 & $\mathrm{C}_{24} \mathrm{H}_{32} \mathrm{O}_{14}$ & 544.179206 \\
\hline $\mathrm{C}_{18} \mathrm{H}_{20} \mathrm{O}_{9} \mathrm{~N}_{2}$ & 408.11688 & $\mathrm{C}_{24} \mathrm{H}_{30} \mathrm{O}_{10}$ & 478.183897 & $\mathrm{C}_{28} \mathrm{H}_{32} \mathrm{O}_{11}$ & 544.194462 \\
\hline $\mathrm{C}_{20} \mathrm{H}_{24} \mathrm{O}_{9}$ & 408.142032 & $\mathrm{C}_{23} \mathrm{H}_{30} \mathrm{O}_{9} \mathrm{~N}_{2}$ & 478.195131 & $\mathrm{C}_{26} \mathrm{H}_{26} \mathrm{O}_{13}$ & 546.137341 \\
\hline $\mathrm{C}_{19} \mathrm{H}_{24} \mathrm{O}_{8} \mathrm{~N}_{2}$ & 408.153266 & $\mathrm{C}_{21} \mathrm{H}_{21} \mathrm{O}_{12} \mathrm{~N}_{1}$ & 479.106375 & $\mathrm{C}_{27} \mathrm{H}_{30} \mathrm{O}_{12}$ & 546.173726 \\
\hline $\mathrm{C}_{18} \mathrm{H}_{19} \mathrm{O}_{10} \mathrm{~N}_{1}$ & 409.100896 & $\mathrm{C}_{22} \mathrm{H}_{25} \mathrm{O}_{11} \mathrm{~N}_{1}$ & 479.142761 & $\mathrm{C}_{28} \mathrm{H}_{34} \mathrm{O}_{11}$ & 546.210112 \\
\hline $\mathrm{C}_{19} \mathrm{H}_{23} \mathrm{O}_{9} \mathrm{~N}_{1}$ & 409.137281 & $\mathrm{C}_{23} \mathrm{H}_{29} \mathrm{O}_{10} \mathrm{~N}_{1}$ & 479.179146 & $\mathrm{C}_{29} \mathrm{H}_{38} \mathrm{O}_{10}$ & 546.246497 \\
\hline $\mathrm{C}_{18} \mathrm{H}_{18} \mathrm{O}_{11}$ & 410.084911 & $\mathrm{C}_{21} \mathrm{H}_{20} \mathrm{O}_{13}$ & 480.090391 & $\mathrm{C}_{25} \mathrm{H}_{24} \mathrm{O}_{14}$ & 548.116605 \\
\hline $\mathrm{C}_{19} \mathrm{H}_{22} \mathrm{O}_{10}$ & 410.121297 & $\mathrm{C}_{20} \mathrm{H}_{20} \mathrm{O}_{12} \mathrm{~N}_{2}$ & 480.101624 & $\mathrm{C}_{26} \mathrm{H}_{28} \mathrm{O}_{13}$ & 548.152991 \\
\hline $\mathrm{C}_{18} \mathrm{H}_{22} \mathrm{O}_{9} \mathrm{~N}_{2}$ & 410.13253 & $\mathrm{C}_{22} \mathrm{H}_{24} \mathrm{O}_{12}$ & 480.126776 & $\mathrm{C}_{25} \mathrm{H}_{28} \mathrm{O}_{12} \mathrm{~N}_{2}$ & 548.164224 \\
\hline $\mathrm{C}_{20} \mathrm{H}_{26} \mathrm{O}_{9}$ & 410.157682 & $\mathrm{C}_{21} \mathrm{H}_{24} \mathrm{O}_{11} \mathrm{~N}_{2}$ & 480.13801 & $\mathrm{C}_{27} \mathrm{H}_{32} \mathrm{O}_{12}$ & 548.189377 \\
\hline $\mathrm{C}_{18} \mathrm{H}_{21} \mathrm{O}_{10} \mathrm{~N}_{1}$ & 411.116546 & $\mathrm{C}_{23} \mathrm{H}_{28} \mathrm{O}_{11}$ & 480.163162 & $\mathrm{C}_{28} \mathrm{H}_{36} \mathrm{O}_{11}$ & 548.225762 \\
\hline $\mathrm{C}_{19} \mathrm{H}_{25} \mathrm{O}_{9} \mathrm{~N}_{1}$ & 411.152931 & $\mathrm{C}_{22} \mathrm{H}_{28} \mathrm{O}_{10} \mathrm{~N}_{2}$ & 480.174395 & $\mathrm{C}_{29} \mathrm{H}_{40} \mathrm{O}_{10}$ & 548.262148 \\
\hline $\mathrm{C}_{18} \mathrm{H}_{20} \mathrm{O}_{11}$ & 412.100562 & $\mathrm{C}_{24} \mathrm{H}_{32} \mathrm{O}_{10}$ & 480.199547 & $\mathrm{C}_{25} \mathrm{H}_{27} \mathrm{O}_{13} \mathrm{~N}_{1}$ & 549.14824 \\
\hline $\mathrm{C}_{19} \mathrm{H}_{24} \mathrm{O}_{10}$ & 412.136947 & $\mathrm{C}_{21} \mathrm{H}_{23} \mathrm{O}_{12} \mathrm{~N}_{1}$ & 481.122025 & $\mathrm{C}_{26} \mathrm{H}_{31} \mathrm{O}_{12} \mathrm{~N}_{1}$ & 549.184625 \\
\hline $\mathrm{C}_{18} \mathrm{H}_{23} \mathrm{O}_{10} \mathrm{~N}_{1}$ & 413.132196 & $\mathrm{C}_{22} \mathrm{H}_{27} \mathrm{O}_{11} \mathrm{~N}_{1}$ & 481.158411 & $\mathrm{C}_{24} \mathrm{H}_{22} \mathrm{O}_{15}$ & 550.09587 \\
\hline $\mathrm{C}_{18} \mathrm{H}_{22} \mathrm{O}_{11}$ & 414.116212 & $\mathrm{C}_{23} \mathrm{H}_{31} \mathrm{O}_{10} \mathrm{~N}_{1}$ & 481.194796 & $\mathrm{C}_{25} \mathrm{H}_{26} \mathrm{O}_{14}$ & 550.132256 \\
\hline $\mathrm{C}_{22} \mathrm{H}_{22} \mathrm{O}_{8}$ & 414.131468 & $\mathrm{C}_{21} \mathrm{H}_{22} \mathrm{O}_{13}$ & 482.106041 & $\mathrm{C}_{26} \mathrm{H}_{30} \mathrm{O}_{13}$ & 550.168641 \\
\hline $\mathrm{C}_{19} \mathrm{H}_{26} \mathrm{O}_{10}$ & 414.152597 & $\mathrm{C}_{22} \mathrm{H}_{26} \mathrm{O}_{12}$ & 482.142426 & $\mathrm{C}_{25} \mathrm{H}_{30} \mathrm{O}_{12} \mathrm{~N}_{2}$ & 550.179874 \\
\hline $\mathrm{C}_{23} \mathrm{H}_{26} \mathrm{O}_{7}$ & 414.167853 & $\mathrm{C}_{21} \mathrm{H}_{26} \mathrm{O}_{11} \mathrm{~N}_{2}$ & 482.15366 & $\mathrm{C}_{27} \mathrm{H}_{34} \mathrm{O}_{12}$ & 550.205027 \\
\hline $\mathrm{C}_{21} \mathrm{H}_{20} \mathrm{O}_{9}$ & 416.110732 & $\mathrm{C}_{23} \mathrm{H}_{30} \mathrm{O}_{11}$ & 482.178812 & $\mathrm{C}_{28} \mathrm{H}_{38} \mathrm{O}_{11}$ & 550.241412 \\
\hline $\mathrm{C}_{18} \mathrm{H}_{24} \mathrm{O}_{11}$ & 416.131862 & $\mathrm{C}_{24} \mathrm{H}_{34} \mathrm{O}_{10}$ & 482.215197 & $\mathrm{C}_{24} \mathrm{H}_{25} \mathrm{O}_{14} \mathrm{~N}_{1}$ & 551.127505 \\
\hline $\mathrm{C}_{22} \mathrm{H}_{24} \mathrm{O}_{8}$ & 416.147118 & $\mathrm{C}_{20} \mathrm{H}_{21} \mathrm{O}_{13} \mathrm{~N}_{1}$ & 483.10129 & $\mathrm{C}_{25} \mathrm{H}_{29} \mathrm{O}_{13} \mathrm{~N}_{1}$ & 551.16389 \\
\hline $\mathrm{C}_{23} \mathrm{H}_{28} \mathrm{O}_{7}$ & 416.183503 & $\mathrm{C}_{21} \mathrm{H}_{25} \mathrm{O}_{12} \mathrm{~N}_{1}$ & 483.137675 & $\mathrm{C}_{26} \mathrm{H}_{33} \mathrm{O}_{12} \mathrm{~N}_{1}$ & 551.200276 \\
\hline $\mathrm{C}_{20} \mathrm{H}_{19} \mathrm{O}_{9} \mathrm{~N}_{1}$ & 417.105981 & $\mathrm{C}_{22} \mathrm{H}_{29} \mathrm{O}_{11} \mathrm{~N}_{1}$ & 483.174061 & $\mathrm{C}_{24} \mathrm{H}_{24} \mathrm{O}_{15}$ & 552.11152 \\
\hline $\mathrm{C}_{21} \mathrm{H}_{23} \mathrm{O}_{8} \mathrm{~N}_{1}$ & 417.142367 & $\mathrm{C}_{21} \mathrm{H}_{24} \mathrm{O}_{11} \mathrm{~S}_{1}$ & 484.103932 & $\mathrm{C}_{25} \mathrm{H}_{28} \mathrm{O}_{14}$ & 552.147906 \\
\hline $\mathrm{C}_{20} \mathrm{H}_{18} \mathrm{O}_{10}$ & 418.089997 & $\mathrm{C}_{21} \mathrm{H}_{24} \mathrm{O}_{13}$ & 484.121691 & $\mathrm{C}_{26} \mathrm{H}_{32} \mathrm{O}_{13}$ & 552.184291 \\
\hline
\end{tabular}


Table A2. Continued.

\begin{tabular}{|c|c|c|c|c|c|}
\hline Elemental Formula & M & Elemental Formula & M & Elemental Formula & M \\
\hline $\mathrm{C}_{19} \mathrm{H}_{18} \mathrm{O}_{9} \mathrm{~N}_{2}$ & 418.10123 & $\mathrm{C}_{22} \mathrm{H}_{28} \mathrm{O}_{12}$ & 484.158076 & $\mathrm{C}_{27} \mathrm{H}_{36} \mathrm{O}_{12}$ & 552.220677 \\
\hline $\mathrm{C}_{21} \mathrm{H}_{22} \mathrm{O}_{9}$ & 418.126382 & $\mathrm{C}_{23} \mathrm{H}_{32} \mathrm{O}_{11}$ & 484.194462 & $\mathrm{C}_{25} \mathrm{H}_{31} \mathrm{O}_{13} \mathrm{~N}_{1}$ & 553.17954 \\
\hline $\mathrm{C}_{22} \mathrm{H}_{26} \mathrm{O}_{8}$ & 418.162768 & $\mathrm{C}_{21} \mathrm{H}_{27} \mathrm{O}_{12} \mathrm{~N}_{1}$ & 485.153325 & $\mathrm{C}_{24} \mathrm{H}_{26} \mathrm{O}_{15}$ & 554.12717 \\
\hline $\mathrm{C}_{19} \mathrm{H}_{17} \mathrm{O}_{10} \mathrm{~N}_{1}$ & 419.085246 & $\mathrm{C}_{21} \mathrm{H}_{26} \mathrm{O}_{13}$ & 486.137341 & $\mathrm{C}_{25} \mathrm{H}_{30} \mathrm{O}_{14}$ & 554.163556 \\
\hline $\mathrm{C}_{20} \mathrm{H}_{21} \mathrm{O}_{9} \mathrm{~N}_{1}$ & 419.121631 & $\mathrm{C}_{25} \mathrm{H}_{26} \mathrm{O}_{10}$ & 486.152597 & $\mathrm{C}_{24} \mathrm{H}_{30} \mathrm{O}_{13} \mathrm{~N}_{2}$ & 554.174789 \\
\hline $\mathrm{C}_{21} \mathrm{H}_{25} \mathrm{O}_{8} \mathrm{~N}_{1}$ & 419.158017 & $\mathrm{C}_{22} \mathrm{H}_{30} \mathrm{O}_{12}$ & 486.173726 & $\mathrm{C}_{26} \mathrm{H}_{34} \mathrm{O}_{13}$ & 554.199941 \\
\hline $\mathrm{C}_{20} \mathrm{H}_{20} \mathrm{O}_{10}$ & 420.105647 & $\mathrm{C}_{26} \mathrm{H}_{30} \mathrm{O}_{9}$ & 486.188983 & $\mathrm{C}_{25} \mathrm{H}_{32} \mathrm{O}_{14}$ & 556.179206 \\
\hline $\mathrm{C}_{19} \mathrm{H}_{20} \mathrm{O}_{9} \mathrm{~N}_{2}$ & 420.11688 & $\mathrm{C}_{20} \mathrm{H}_{25} \mathrm{O}_{13} \mathrm{~N}_{1}$ & 487.13259 & $\mathrm{C}_{26} \mathrm{H}_{36} \mathrm{O}_{13}$ & 556.215591 \\
\hline $\mathrm{C}_{21} \mathrm{H}_{24} \mathrm{O}_{9}$ & 420.142032 & $\mathrm{C}_{23} \mathrm{H}_{20} \mathrm{O}_{12}$ & 488.095476 & $\mathrm{C}_{24} \mathrm{H}_{30} \mathrm{O}_{15}$ & 558.15847 \\
\hline $\mathrm{C}_{20} \mathrm{H}_{24} \mathrm{O}_{8} \mathrm{~N}_{2}$ & 420.153266 & $\mathrm{C}_{20} \mathrm{H}_{24} \mathrm{O}_{14}$ & 488.116605 & $\mathrm{C}_{25} \mathrm{H}_{34} \mathrm{O}_{14}$ & 558.194856 \\
\hline $\mathrm{C}_{20} \mathrm{H}_{23} \mathrm{O}_{9} \mathrm{~N}_{1}$ & 421.137281 & $\mathrm{C}_{24} \mathrm{H}_{24} \mathrm{O}_{11}$ & 488.131862 & $\mathrm{C}_{29} \mathrm{H}_{34} \mathrm{O}_{11}$ & 558.210112 \\
\hline $\mathrm{C}_{21} \mathrm{H}_{27} \mathrm{O}_{8} \mathrm{~N}_{1}$ & 421.173667 & $\mathrm{C}_{21} \mathrm{H}_{28} \mathrm{O}_{13}$ & 488.152991 & $\mathrm{C}_{27} \mathrm{H}_{28} \mathrm{O}_{13}$ & 560.152991 \\
\hline $\mathrm{C}_{19} \mathrm{H}_{18} \mathrm{O}_{11}$ & 422.084911 & $\mathrm{C}_{25} \mathrm{H}_{28} \mathrm{O}_{10}$ & 488.168247 & $\mathrm{C}_{28} \mathrm{H}_{32} \mathrm{O}_{12}$ & 560.189377 \\
\hline $\mathrm{C}_{18} \mathrm{H}_{18} \mathrm{O}_{10} \mathrm{~N}_{2}$ & 422.096145 & $\mathrm{C}_{26} \mathrm{H}_{32} \mathrm{O}_{9}$ & 488.204633 & $\mathrm{C}_{29} \mathrm{H}_{36} \mathrm{O}_{11}$ & 560.225762 \\
\hline $\mathrm{C}_{20} \mathrm{H}_{22} \mathrm{O}_{10}$ & 422.121297 & $\mathrm{C}_{23} \mathrm{H}_{23} \mathrm{O}_{11} \mathrm{~N}_{1}$ & 489.127111 & $\mathrm{C}_{26} \mathrm{H}_{26} \mathrm{O}_{14}$ & 562.132256 \\
\hline $\mathrm{C}_{19} \mathrm{H}_{22} \mathrm{O}_{9} \mathrm{~N}_{2}$ & 422.13253 & $\mathrm{C}_{24} \mathrm{H}_{27} \mathrm{O}_{10} \mathrm{~N}_{1}$ & 489.163496 & $\mathrm{C}_{27} \mathrm{H}_{30} \mathrm{O}_{13}$ & 562.168641 \\
\hline $\mathrm{C}_{21} \mathrm{H}_{26} \mathrm{O}_{9}$ & 422.157682 & $\mathrm{C}_{23} \mathrm{H}_{22} \mathrm{O}_{12}$ & 490.111126 & $\mathrm{C}_{28} \mathrm{H}_{34} \mathrm{O}_{12}$ & 562.205027 \\
\hline $\mathrm{C}_{20} \mathrm{H}_{26} \mathrm{O}_{8} \mathrm{~N}_{2}$ & 422.168916 & $\mathrm{C}_{22} \mathrm{H}_{22} \mathrm{O}_{11} \mathrm{~N}_{2}$ & 490.12236 & $\mathrm{C}_{29} \mathrm{H}_{38} \mathrm{O}_{11}$ & 562.241412 \\
\hline $\mathrm{C}_{19} \mathrm{H}_{21} \mathrm{O}_{10} \mathrm{~N}_{1}$ & 423.116546 & $\mathrm{C}_{24} \mathrm{H}_{26} \mathrm{O}_{11}$ & 490.147512 & $\mathrm{C}_{26} \mathrm{H}_{29} \mathrm{O}_{13} \mathrm{~N}_{1}$ & 563.16389 \\
\hline $\mathrm{C}_{20} \mathrm{H}_{25} \mathrm{O}_{9} \mathrm{~N}_{1}$ & 423.152931 & $\mathrm{C}_{23} \mathrm{H}_{26} \mathrm{O}_{10} \mathrm{~N}_{2}$ & 490.158745 & $\mathrm{C}_{25} \mathrm{H}_{24} \mathrm{O}_{15}$ & 564.11152 \\
\hline $\mathrm{C}_{19} \mathrm{H}_{20} \mathrm{O}_{11}$ & 424.100562 & $\mathrm{C}_{25} \mathrm{H}_{30} \mathrm{O}_{10}$ & 490.183897 & $\mathrm{C}_{26} \mathrm{H}_{28} \mathrm{O}_{14}$ & 564.147906 \\
\hline $\mathrm{C}_{18} \mathrm{H}_{20} \mathrm{O}_{10} \mathrm{~N}_{2}$ & 424.111795 & $\mathrm{C}_{26} \mathrm{H}_{34} \mathrm{O}_{9}$ & 490.220283 & $\mathrm{C}_{25} \mathrm{H}_{28} \mathrm{O}_{13} \mathrm{~N}_{2}$ & 564.159139 \\
\hline $\mathrm{C}_{20} \mathrm{H}_{24} \mathrm{O}_{10}$ & 424.136947 & $\mathrm{C}_{22} \mathrm{H}_{21} \mathrm{O}_{12} \mathrm{~N}_{1}$ & 491.106375 & $\mathrm{C}_{27} \mathrm{H}_{32} \mathrm{O}_{13}$ & 564.184291 \\
\hline $\mathrm{C}_{19} \mathrm{H}_{24} \mathrm{O}_{9} \mathrm{~N}_{2}$ & 424.14818 & $\mathrm{C}_{23} \mathrm{H}_{25} \mathrm{O}_{11} \mathrm{~N}_{1}$ & 491.142761 & $\mathrm{C}_{28} \mathrm{H}_{36} \mathrm{O}_{12}$ & 564.220677 \\
\hline $\mathrm{C}_{19} \mathrm{H}_{23} \mathrm{O}_{10} \mathrm{~N}_{1}$ & 425.132196 & $\mathrm{C}_{24} \mathrm{H}_{29} \mathrm{O}_{10} \mathrm{~N}_{1}$ & 491.179146 & $\mathrm{C}_{29} \mathrm{H}_{40} \mathrm{O}_{11}$ & 564.257062 \\
\hline $\mathrm{C}_{20} \mathrm{H}_{27} \mathrm{O}_{9} \mathrm{~N}_{1}$ & 425.168582 & $\mathrm{C}_{22} \mathrm{H}_{20} \mathrm{O}_{13}$ & 492.090391 & $\mathrm{C}_{25} \mathrm{H}_{27} \mathrm{O}_{14} \mathrm{~N}_{1}$ & 565.143155 \\
\hline $\mathrm{C}_{18} \mathrm{H}_{18} \mathrm{O}_{12}$ & 426.079826 & $\mathrm{C}_{21} \mathrm{H}_{20} \mathrm{O}_{12} \mathrm{~N}_{2}$ & 492.101624 & $\mathrm{C}_{26} \mathrm{H}_{31} \mathrm{O}_{13} \mathrm{~N}_{1}$ & 565.17954 \\
\hline $\mathrm{C}_{19} \mathrm{H}_{22} \mathrm{O}_{11}$ & 426.116212 & $\mathrm{C}_{23} \mathrm{H}_{24} \mathrm{O}_{12}$ & 492.126776 & $\mathrm{C}_{25} \mathrm{H}_{26} \mathrm{O}_{15}$ & 566.12717 \\
\hline $\mathrm{C}_{18} \mathrm{H}_{22} \mathrm{O}_{10} \mathrm{~N}_{2}$ & 426.127445 & $\mathrm{C}_{22} \mathrm{H}_{24} \mathrm{O}_{11} \mathrm{~N}_{2}$ & 492.13801 & $\mathrm{C}_{26} \mathrm{H}_{30} \mathrm{O}_{14}$ & 566.163556 \\
\hline $\mathrm{C}_{20} \mathrm{H}_{26} \mathrm{O}_{10}$ & 426.152597 & $\mathrm{C}_{24} \mathrm{H}_{28} \mathrm{O}_{11}$ & 492.163162 & $\mathrm{C}_{27} \mathrm{H}_{34} \mathrm{O}_{13}$ & 566.199941 \\
\hline $\mathrm{C}_{18} \mathrm{H}_{21} \mathrm{O}_{11} \mathrm{~N}_{1}$ & 427.111461 & $\mathrm{C}_{23} \mathrm{H}_{28} \mathrm{O}_{10} \mathrm{~N}_{2}$ & 492.174395 & $\mathrm{C}_{28} \mathrm{H}_{38} \mathrm{O}_{12}$ & 566.236327 \\
\hline $\mathrm{C}_{19} \mathrm{H}_{25} \mathrm{O}_{10} \mathrm{~N}_{1}$ & 427.147846 & $\mathrm{C}_{25} \mathrm{H}_{32} \mathrm{O}_{10}$ & 492.199547 & $\mathrm{C}_{24} \mathrm{H}_{25} \mathrm{O}_{15} \mathrm{~N}_{1}$ & 567.122419 \\
\hline $\mathrm{C}_{18} \mathrm{H}_{20} \mathrm{O}_{12}$ & 428.095476 & $\mathrm{C}_{22} \mathrm{H}_{23} \mathrm{O}_{12} \mathrm{~N}_{1}$ & 493.122025 & $\mathrm{C}_{26} \mathrm{H}_{33} \mathrm{O}_{13} \mathrm{~N}_{1}$ & 567.19519 \\
\hline $\mathrm{C}_{19} \mathrm{H}_{24} \mathrm{O}_{11}$ & 428.131862 & $\mathrm{C}_{23} \mathrm{H}_{27} \mathrm{O}_{11} \mathrm{~N}_{1}$ & 493.158411 & $\mathrm{C}_{25} \mathrm{H}_{28} \mathrm{O}_{15}$ & 568.14282 \\
\hline $\mathrm{C}_{20} \mathrm{H}_{28} \mathrm{O}_{10}$ & 428.168247 & $\mathrm{C}_{24} \mathrm{H}_{31} \mathrm{O}_{10} \mathrm{~N}_{1}$ & 493.194796 & $\mathrm{C}_{26} \mathrm{H}_{32} \mathrm{O}_{14}$ & 568.179206 \\
\hline $\mathrm{C}_{21} \mathrm{H}_{18} \mathrm{O}_{10}$ & 430.089997 & $\mathrm{C}_{22} \mathrm{H}_{22} \mathrm{O}_{13}$ & 494.106041 & $\mathrm{C}_{27} \mathrm{H}_{36} \mathrm{O}_{13}$ & 568.215591 \\
\hline $\mathrm{C}_{22} \mathrm{H}_{22} \mathrm{O}_{9}$ & 430.126382 & $\mathrm{C}_{21} \mathrm{H}_{22} \mathrm{O}_{12} \mathrm{~N}_{2}$ & 494.117274 & $\mathrm{C}_{25} \mathrm{H}_{31} \mathrm{O}_{14} \mathrm{~N}_{1}$ & 569.174455 \\
\hline $\mathrm{C}_{19} \mathrm{H}_{26} \mathrm{O}_{11}$ & 430.147512 & $\mathrm{C}_{23} \mathrm{H}_{26} \mathrm{O}_{12}$ & 494.142426 & $\mathrm{C}_{25} \mathrm{H}_{30} \mathrm{O}_{15}$ & 570.15847 \\
\hline $\mathrm{C}_{23} \mathrm{H}_{26} \mathrm{O}_{8}$ & 430.162768 & $\mathrm{C}_{22} \mathrm{H}_{26} \mathrm{O}_{11} \mathrm{~N}_{2}$ & 494.15366 & $\mathrm{C}_{26} \mathrm{H}_{34} \mathrm{O}_{14}$ & 570.194856 \\
\hline $\mathrm{C}_{21} \mathrm{H}_{21} \mathrm{O}_{9} \mathrm{~N}_{1}$ & 431.121631 & $\mathrm{C}_{24} \mathrm{H}_{30} \mathrm{O}_{11}$ & 494.178812 & $\mathrm{C}_{28} \mathrm{H}_{30} \mathrm{O}_{13}$ & 574.168641 \\
\hline $\mathrm{C}_{21} \mathrm{H}_{20} \mathrm{O}_{10}$ & 432.105647 & $\mathrm{C}_{23} \mathrm{H}_{30} \mathrm{O}_{10} \mathrm{~N}_{2}$ & 494.190045 & $\mathrm{C}_{29} \mathrm{H}_{34} \mathrm{O}_{12}$ & 574.205027 \\
\hline $\mathrm{C}_{20} \mathrm{H}_{20} \mathrm{O}_{9} \mathrm{~N}_{2}$ & 432.11688 & $\mathrm{C}_{25} \mathrm{H}_{34} \mathrm{O}_{10}$ & 494.215197 & $\mathrm{C}_{30} \mathrm{H}_{38} \mathrm{O}_{11}$ & 574.241412 \\
\hline $\mathrm{C}_{22} \mathrm{H}_{24} \mathrm{O}_{9}$ & 432.142032 & $\mathrm{C}_{21} \mathrm{H}_{21} \mathrm{O}_{13} \mathrm{~N}_{1}$ & 495.10129 & $\mathrm{C}_{27} \mathrm{H}_{28} \mathrm{O}_{14}$ & 576.147906 \\
\hline $\mathrm{C}_{21} \mathrm{H}_{24} \mathrm{O}_{8} \mathrm{~N}_{2}$ & 432.153266 & $\mathrm{C}_{22} \mathrm{H}_{25} \mathrm{O}_{12} \mathrm{~N}_{1}$ & 495.137675 & $\mathrm{C}_{28} \mathrm{H}_{32} \mathrm{O}_{13}$ & 576.184291 \\
\hline $\mathrm{C}_{23} \mathrm{H}_{28} \mathrm{O}_{8}$ & 432.178418 & $\mathrm{C}_{23} \mathrm{H}_{29} \mathrm{O}_{11} \mathrm{~N}_{1}$ & 495.174061 & $\mathrm{C}_{29} \mathrm{H}_{36} \mathrm{O}_{12}$ & 576.220677 \\
\hline $\mathrm{C}_{20} \mathrm{H}_{19} \mathrm{O}_{10} \mathrm{~N}_{1}$ & 433.100896 & $\mathrm{C}_{22} \mathrm{H}_{24} \mathrm{O}_{13}$ & 496.121691 & $\mathrm{C}_{30} \mathrm{H}_{40} \mathrm{O}_{11}$ & 576.257062 \\
\hline $\mathrm{C}_{21} \mathrm{H}_{23} \mathrm{O}_{9} \mathrm{~N}_{1}$ & 433.137281 & $\mathrm{C}_{21} \mathrm{H}_{24} \mathrm{O}_{12} \mathrm{~N}_{2}$ & 496.132924 & $\mathrm{C}_{26} \mathrm{H}_{26} \mathrm{O}_{15}$ & 578.12717 \\
\hline $\mathrm{C}_{22} \mathrm{H}_{27} \mathrm{O}_{8} \mathrm{~N}_{1}$ & 433.173667 & $\mathrm{C}_{23} \mathrm{H}_{28} \mathrm{O}_{12}$ & 496.158076 & $\mathrm{C}_{27} \mathrm{H}_{30} \mathrm{O}_{14}$ & 578.163556 \\
\hline $\mathrm{C}_{20} \mathrm{H}_{18} \mathrm{O}_{11}$ & 434.084911 & $\mathrm{C}_{22} \mathrm{H}_{28} \mathrm{O}_{11} \mathrm{~N}_{2}$ & 496.16931 & $\mathrm{C}_{28} \mathrm{H}_{34} \mathrm{O}_{13}$ & 578.199941 \\
\hline $\mathrm{C}_{19} \mathrm{H}_{18} \mathrm{O}_{10} \mathrm{~N}_{2}$ & 434.096145 & $\mathrm{C}_{24} \mathrm{H}_{32} \mathrm{O}_{11}$ & 496.194462 & $\mathrm{C}_{29} \mathrm{H}_{38} \mathrm{O}_{12}$ & 578.236327 \\
\hline $\mathrm{C}_{21} \mathrm{H}_{22} \mathrm{O}_{10}$ & 434.121297 & $\mathrm{C}_{21} \mathrm{H}_{23} \mathrm{O}_{13} \mathrm{~N}_{1}$ & 497.11694 & $\mathrm{C}_{26} \mathrm{H}_{29} \mathrm{O}_{14} \mathrm{~N}_{1}$ & 579.158805 \\
\hline $\mathrm{C}_{20} \mathrm{H}_{22} \mathrm{O}_{9} \mathrm{~N}_{2}$ & 434.13253 & $\mathrm{C}_{22} \mathrm{H}_{27} \mathrm{O}_{12} \mathrm{~N}_{1}$ & 497.153325 & $\mathrm{C}_{26} \mathrm{H}_{28} \mathrm{O}_{15}$ & 580.14282 \\
\hline $\mathrm{C}_{22} \mathrm{H}_{26} \mathrm{O}_{9}$ & 434.157682 & $\mathrm{C}_{21} \mathrm{H}_{22} \mathrm{O}_{14}$ & 498.100955 & $\mathrm{C}_{27} \mathrm{H}_{32} \mathrm{O}_{14}$ & 580.179206 \\
\hline $\mathrm{C}_{21} \mathrm{H}_{26} \mathrm{O}_{8} \mathrm{~N}_{2}$ & 434.168916 & $\mathrm{C}_{22} \mathrm{H}_{26} \mathrm{O}_{13}$ & 498.137341 & $\mathrm{C}_{28} \mathrm{H}_{36} \mathrm{O}_{13}$ & 580.215591 \\
\hline $\mathrm{C}_{19} \mathrm{H}_{17} \mathrm{O}_{11} \mathrm{~N}_{1}$ & 435.08016 & $\mathrm{C}_{21} \mathrm{H}_{26} \mathrm{O}_{12} \mathrm{~N}_{2}$ & 498.148574 & $\mathrm{C}_{29} \mathrm{H}_{40} \mathrm{O}_{12}$ & 580.251977 \\
\hline $\mathrm{C}_{20} \mathrm{H}_{21} \mathrm{O}_{10} \mathrm{~N}_{1}$ & 435.116546 & $\mathrm{C}_{23} \mathrm{H}_{30} \mathrm{O}_{12}$ & 498.173726 & $\mathrm{C}_{25} \mathrm{H}_{27} \mathrm{O}_{15} \mathrm{~N}_{1}$ & 581.138069 \\
\hline
\end{tabular}


Table A2. Continued.

\begin{tabular}{|c|c|c|c|c|c|}
\hline Elemental Formula & M & Elemental Formula & M & Elemental Formula & M \\
\hline $\mathrm{C}_{21} \mathrm{H}_{25} \mathrm{O}_{9} \mathrm{~N}_{1}$ & 435.152931 & $\mathrm{C}_{24} \mathrm{H}_{34} \mathrm{O}_{11}$ & 498.210112 & $\mathrm{C}_{26} \mathrm{H}_{31} \mathrm{O}_{14} \mathrm{~N}_{1}$ & 581.174455 \\
\hline $\mathrm{C}_{20} \mathrm{H}_{20} \mathrm{O}_{11}$ & 436.100562 & $\mathrm{C}_{21} \mathrm{H}_{25} \mathrm{O}_{13} \mathrm{~N}_{1}$ & 499.13259 & $\mathrm{C}_{25} \mathrm{H}_{26} \mathrm{O}_{16}$ & 582.122085 \\
\hline $\mathrm{C}_{19} \mathrm{H}_{20} \mathrm{O}_{10} \mathrm{~N}_{2}$ & 436.111795 & $\mathrm{C}_{22} \mathrm{H}_{29} \mathrm{O}_{12} \mathrm{~N}_{1}$ & 499.168975 & $\mathrm{C}_{26} \mathrm{H}_{30} \mathrm{O}_{15}$ & 582.15847 \\
\hline $\mathrm{C}_{21} \mathrm{H}_{24} \mathrm{O}_{10}$ & 436.136947 & $\mathrm{C}_{21} \mathrm{H}_{24} \mathrm{O}_{14}$ & 500.116605 & $\mathrm{C}_{25} \mathrm{H}_{30} \mathrm{O}_{14} \mathrm{~N}_{2}$ & 582.169704 \\
\hline $\mathrm{C}_{20} \mathrm{H}_{24} \mathrm{O}_{9} \mathrm{~N}_{2}$ & 436.14818 & $\mathrm{C}_{22} \mathrm{H}_{28} \mathrm{O}_{13}$ & 500.152991 & $\mathrm{C}_{27} \mathrm{H}_{34} \mathrm{O}_{14}$ & 582.194856 \\
\hline $\mathrm{C}_{22} \mathrm{H}_{28} \mathrm{O}_{9}$ & 436.173333 & $\mathrm{C}_{26} \mathrm{H}_{28} \mathrm{O}_{10}$ & 500.168247 & $\mathrm{C}_{28} \mathrm{H}_{38} \mathrm{O}_{13}$ & 582.231241 \\
\hline $\mathrm{C}_{19} \mathrm{H}_{19} \mathrm{O}_{11} \mathrm{~N}_{1}$ & 437.09581 & $\mathrm{C}_{23} \mathrm{H}_{32} \mathrm{O}_{12}$ & 500.189377 & $\mathrm{C}_{26} \mathrm{H}_{32} \mathrm{O}_{15}$ & 584.17412 \\
\hline $\mathrm{C}_{20} \mathrm{H}_{23} \mathrm{O}_{10} \mathrm{~N}_{1}$ & 437.132196 & $\mathrm{C}_{24} \mathrm{H}_{22} \mathrm{O}_{12}$ & 502.111126 & $\mathrm{C}_{27} \mathrm{H}_{36} \mathrm{O}_{14}$ & 584.210506 \\
\hline $\mathrm{C}_{21} \mathrm{H}_{27} \mathrm{O}_{9} \mathrm{~N}_{1}$ & 437.168582 & $\mathrm{C}_{21} \mathrm{H}_{26} \mathrm{O}_{14}$ & 502.132256 & $\mathrm{C}_{26} \mathrm{H}_{34} \mathrm{O}_{15}$ & 586.18977 \\
\hline $\mathrm{C}_{19} \mathrm{H}_{18} \mathrm{O}_{12}$ & 438.079826 & $\mathrm{C}_{25} \mathrm{H}_{26} \mathrm{O}_{11}$ & 502.147512 & $\mathrm{C}_{29} \mathrm{H}_{32} \mathrm{O}_{13}$ & 588.184291 \\
\hline $\mathrm{C}_{20} \mathrm{H}_{22} \mathrm{O}_{11}$ & 438.116212 & $\mathrm{C}_{26} \mathrm{H}_{30} \mathrm{O}_{10}$ & 502.183897 & $\mathrm{C}_{30} \mathrm{H}_{36} \mathrm{O}_{12}$ & 588.220677 \\
\hline $\mathrm{C}_{19} \mathrm{H}_{22} \mathrm{O}_{10} \mathrm{~N}_{2}$ & 438.127445 & $\mathrm{C}_{27} \mathrm{H}_{34} \mathrm{O}_{9}$ & 502.220283 & $\mathrm{C}_{28} \mathrm{H}_{30} \mathrm{O}_{14}$ & 590.163556 \\
\hline $\mathrm{C}_{21} \mathrm{H}_{26} \mathrm{O}_{10}$ & 438.152597 & $\mathrm{C}_{23} \mathrm{H}_{20} \mathrm{O}_{13}$ & 504.090391 & $\mathrm{C}_{29} \mathrm{H}_{34} \mathrm{O}_{13}$ & 590.199941 \\
\hline $\mathrm{C}_{22} \mathrm{H}_{30} \mathrm{O}_{9}$ & 438.188983 & $\mathrm{C}_{24} \mathrm{H}_{24} \mathrm{O}_{12}$ & 504.126776 & $\mathrm{C}_{30} \mathrm{H}_{38} \mathrm{O}_{12}$ & 590.236327 \\
\hline $\mathrm{C}_{19} \mathrm{H}_{21} \mathrm{O}_{11} \mathrm{~N}_{1}$ & 439.111461 & $\mathrm{C}_{23} \mathrm{H}_{24} \mathrm{O}_{11} \mathrm{~N}_{2}$ & 504.13801 & $\mathrm{C}_{27} \mathrm{H}_{28} \mathrm{O}_{15}$ & 592.14282 \\
\hline $\mathrm{C}_{20} \mathrm{H}_{25} \mathrm{O}_{10} \mathrm{~N}_{1}$ & 439.147846 & $\mathrm{C}_{25} \mathrm{H}_{28} \mathrm{O}_{11}$ & 504.163162 & $\mathrm{C}_{28} \mathrm{H}_{32} \mathrm{O}_{14}$ & 592.179206 \\
\hline $\mathrm{C}_{19} \mathrm{H}_{20} \mathrm{O}_{12}$ & 440.095476 & $\mathrm{C}_{24} \mathrm{H}_{28} \mathrm{O}_{10} \mathrm{~N}_{2}$ & 504.174395 & $\mathrm{C}_{29} \mathrm{H}_{36} \mathrm{O}_{13}$ & 592.215591 \\
\hline $\mathrm{C}_{20} \mathrm{H}_{24} \mathrm{O}_{11}$ & 440.131862 & $\mathrm{C}_{26} \mathrm{H}_{32} \mathrm{O}_{10}$ & 504.199547 & $\mathrm{C}_{30} \mathrm{H}_{40} \mathrm{O}_{12}$ & 592.251977 \\
\hline $\mathrm{C}_{19} \mathrm{H}_{24} \mathrm{O}_{10} \mathrm{~N}_{2}$ & 440.143095 & $\mathrm{C}_{27} \mathrm{H}_{36} \mathrm{O}_{9}$ & 504.235933 & $\mathrm{C}_{27} \mathrm{H}_{30} \mathrm{O}_{15}$ & 594.15847 \\
\hline $\mathrm{C}_{21} \mathrm{H}_{28} \mathrm{O}_{10}$ & 440.168247 & $\mathrm{C}_{23} \mathrm{H}_{23} \mathrm{O}_{12} \mathrm{~N}_{1}$ & 505.122025 & $\mathrm{C}_{28} \mathrm{H}_{34} \mathrm{O}_{14}$ & 594.194856 \\
\hline $\mathrm{C}_{19} \mathrm{H}_{23} \mathrm{O}_{11} \mathrm{~N}_{1}$ & 441.127111 & $\mathrm{C}_{24} \mathrm{H}_{27} \mathrm{O}_{11} \mathrm{~N}_{1}$ & 505.158411 & $\mathrm{C}_{29} \mathrm{H}_{38} \mathrm{O}_{13}$ & 594.231241 \\
\hline $\mathrm{C}_{20} \mathrm{H}_{27} \mathrm{O}_{10} \mathrm{~N}_{1}$ & 441.163496 & $\mathrm{C}_{25} \mathrm{H}_{31} \mathrm{O}_{10} \mathrm{~N}_{1}$ & 505.194796 & $\mathrm{C}_{27} \mathrm{H}_{33} \mathrm{O}_{14} \mathrm{~N}_{1}$ & 595.190105 \\
\hline $\mathrm{C}_{19} \mathrm{H}_{22} \mathrm{O}_{12}$ & 442.111126 & $\mathrm{C}_{23} \mathrm{H}_{22} \mathrm{O}_{13}$ & 506.106041 & $\mathrm{C}_{26} \mathrm{H}_{28} \mathrm{O}_{16}$ & 596.137735 \\
\hline $\mathrm{C}_{20} \mathrm{H}_{26} \mathrm{O}_{11}$ & 442.147512 & $\mathrm{C}_{22} \mathrm{H}_{22} \mathrm{O}_{12} \mathrm{~N}_{2}$ & 506.117274 & $\mathrm{C}_{27} \mathrm{H}_{32} \mathrm{O}_{15}$ & 596.17412 \\
\hline $\mathrm{C}_{22} \mathrm{H}_{20} \mathrm{O}_{10}$ & 444.105647 & $\mathrm{C}_{24} \mathrm{H}_{26} \mathrm{O}_{12}$ & 506.142426 & $\mathrm{C}_{28} \mathrm{H}_{36} \mathrm{O}_{14}$ & 596.210506 \\
\hline $\mathrm{C}_{19} \mathrm{H}_{24} \mathrm{O}_{12}$ & 444.126776 & $\mathrm{C}_{23} \mathrm{H}_{26} \mathrm{O}_{11} \mathrm{~N}_{2}$ & 506.15366 & $\mathrm{C}_{26} \mathrm{H}_{30} \mathrm{O}_{16}$ & 598.153385 \\
\hline $\mathrm{C}_{23} \mathrm{H}_{24} \mathrm{O}_{9}$ & 444.142032 & $\mathrm{C}_{25} \mathrm{H}_{30} \mathrm{O}_{11}$ & 506.178812 & $\mathrm{C}_{27} \mathrm{H}_{34} \mathrm{O}_{15}$ & 598.18977 \\
\hline $\mathrm{C}_{20} \mathrm{H}_{28} \mathrm{O}_{11}$ & 444.163162 & $\mathrm{C}_{24} \mathrm{H}_{30} \mathrm{O}_{10} \mathrm{~N}_{2}$ & 506.190045 & & \\
\hline $\mathrm{C}_{24} \mathrm{H}_{28} \mathrm{O}_{8}$ & 444.178418 & $\mathrm{C}_{26} \mathrm{H}_{34} \mathrm{O}_{10}$ & 506.215197 & & \\
\hline
\end{tabular}

\section{References}

Aluwihare, L. I., Repta, D. J., and Chen, R. F.: A major biopolymeric component to dissolved organic carbon in surface water, Nature, 387, 166-169, 1997.

Amon, R. M. W. and Benner, R.: Bacterial utilization of different size classes of dissolved organic matter, Limnol. Oceanogr., 41, 41-51, 1996.

Bauer, J. E.: Carbon isotopic composition of DOM, in: Biogeochemistry of marine dissolved organic matter, edited by: Hansell, D. A. and Carlson, C. A., Amsterdam, Academic Press, 405-446, 2002.

Bauer, J. E., Williams, P. M., and Druffel, E. R. M.: ${ }^{14} \mathrm{C}$ activity of dissolved organic carbon fractions in north-central Pacific and Sargasso Sea, Nature, 357, 667-670, 1992.

Beaupre, S. R. and Aluwihare, L.: Constraining the 2-component model of marine dissolved organic radiocarbon, Deep-Sea Res. II, 57, 1494-1503, 2010.

Beaupre, S. R. and Druffel, E. R. M.: Constraining the propagation of bomb-radiocarbon through the dissolved organic carbon (DOC) pool in the northeast Pacific Ocean, Deep-Sea Res. I, 56, 1717-1726, 2009.

Benner, R.: Chemical composition and reactivity, in: Biogeochemistry of marine dissolved organic matter, edited by: Hansell,
D. A. and Carlson, C. A., Amsterdam, Academic Press, 59-85, 2002.

Benner, R. and Herndl, G. J.: Bacterially derived dissolved organic matter in the microbial carbon pump, in: Microbial Carbon Pump in the Ocean, edited by: Jiao, N., Azam, F., and Sanders, S., Science/AAAS, Washington, DC, Science/AAAS, 46-48, 2011.

Benner, R. and Kaiser, K.: Abundance of amino sugars and peptidoglycan in marine particulate and dissolved organic matter, Limnol. Oceanogr., 48, 118-128, 2003.

Bhatia, M. P., Das, S. B., Longnecker, K., Charette, M. A., and Kujawinski, L. E.: Molecular characterization of dissolved organic matter associated with the Greenland ice sheet, Geochim. Cosmochim. Acta, 74, 3768-3784, 2010.

Carlson, C. A. and Ducklow, H. W.: Growth of bacterioplankton and consumption of dissolved organic carbon in the oligotrophic Sargasso Sea, Aquat. Microb. Ecol., 10, 69-85, 1996.

Carlson, C. A., Ducklow, H. W., and Michaels, A. F.: Annual flux of dissolved organic carbon from the euphotic zone in the northwestern Sargasso Sea, Nature, 371, 405-408, 1994.

Carlson, C. A., Hansell, D. A., Nelson, N. B., Siegel, D. A., Smethie, W. M., Khatiwala, S., Meyers, M. M., and Halewood, E.: Dissolved organic carbon export and subsequent remineralization in the mesopelagic and bathypelagic realms of the North Atlantic basin, Deep-Sea Res. II, 57, 1433-1445, 2010. 
Davis, J., Kaiser, K., and Benner, R.: Amino acid and amino sugar yields and compositions as indicators of dissolved organic matter diagenesis, Org. Geochem., 40, 343-352, 2009.

Dittmar, T. and Kattner, G.: Recalcitrant dissolved organic matter in the ocean: major contribution of small amphiphilics, Mar. Chem., 82, 115-123, 2003.

Dittmar, T., Koch, B. P., Hertkorn, N., and Kattner, G.: A simple and efficient method for the solid-phase extraction of dissolved organic matter (SPE-DOM) from seawater, Limnol. Oceanogr.Methods, 6, 230-235, 2008.

Druffel, E. R. M. and Bauer, J. E., Radiocarbon distributions in Southern Ocean dissolved and particulate organic matter, Geophys. Res. Lett., 27, 1495-1498, 2000.

Druffel, E. R. M., Williams, P. M., and Suzuki, Y.: Concentrations and radiocarbon signatures of dissolved organic matter in the Pacific Ocean, Geophys. Res. Lett., 16, 991-994, 1989.

Druffel, E. R. M., Williams, P. M., Bauer, J. E., and Ertel, J. R.: Cycling of dissolved and particulate organic matter in the open ocean, J. Geophys. Res., 97, 15639-15659, 1992.

Flerus, R., Koch, B. P., Schmitt-Kopplin, P., Witt, M., and Kattner, G.: Molecular level investigation of reactions between dissolved organic matter and extraction solvents using FT-ICR MS, Mar. Chem., 124, 100-107, 2011.

Goldberg, S. J., Carlson, C. A., Hansell, D. A., Nelson, N. B., and Siegel, D. A.: Temporal dynamics of dissolved combined neutral sugars and the quality of dissolved organic matter in the Northwestern Sargasso Sea, Deep-Sea Res. I., 56, 672-685, 2009.

Gonsior, M., Peake, B. M., Cooper, W. T., Podgorski, D. C., D'Andrilli, J., Dittmar, T., and Cooper, W. J.: Characterization of dissolved organic matter across the Subtropical Convergence off the South Island, New Zealand, Mar. Chem., 123, 99-110, 2011.

Hansell, D. A. and Carlson, C. A.: Deep-ocean gradients in the concentration of dissolved organic carbon, Nature, 395, 263-266, 1998.

Hansell, D. A., Carlson, C. A., Repeta, D. J., and Schlitzer, R.: Dissolved organic matter in the ocean, Oceanogr., 22, 202-211, 2009.

Hansell, D. A., Carlson, C. A., and Schlitzer, R.: Net removal of major marine dissolved organic carbon fractions in the subsurface ocean, Global Biogeochem. Cy., 26, GB1016, doi:10.1029/2011GB004069, 2012.

Hedges, J. I.: Global biogeochemical cycles: progress and problems, Mar. Chem., 39, 67-93, 1992.

Hertkorn, N., Benner, R., Frommberger, M., Schmitt-Kopplin, P., Witt, M., Kaiser, K., Kettrup, A., and Hedges, J. I.: Characterization of a major refractory component of marine dissolved organic matter, Geochim. Cosmochim. Acta, 70, 2990-3010, 2006.

Hertkorn, N., Ruecker, C., Meringer, M., Gugisch, R., Frommberger, M., Perdue, E. M., Witt, M., and Schmitt-Kopplin, P.: High-precision frequency measurements: indispensable tools at the core of the molecular-level analysis of complex systems, Anal. Bioanal. Chem., 389, 1311-1327, 2007.

Hertkorn, N., Harir, M., Koch, B. P., Michalke, B., Grill, P., and Schmitt-Kopplin, P.: High field NMR spectroscopy and FTICR mass spectrometry: powerful discovery tools for the molecular level characterization of marine dissolved organic matter from the South Atlantic Ocean, Biogeosciences Discuss., 9, 745-833, doi:10.5194/bgd-9-745-2012, 2012.

Jiao, N., Herndl, G. J., Hansell, D. A., Benner, R., Kattner, G., Wilhelm, S. W., Kirchman, D., Weinbauer, M. G., Luo, T., Chen, F., and Azam, F.: Microbial production of recalcitrant dissolved organic matter: long-term carbon storage in the global ocean, Nature Rev. Microbiol., 8, 593-599, 2010.

Kaiser, K. and Benner, R.: Determination of amino sugars in environmental samples with high salt content by high-performance anion-exchange chromatography and pulsed amperometric detection, Anal. Chem., 72, 2566-2572, 2000.

Kaiser, K. and Benner, R.: Biochemical composition and size distribution of organic matter at the Pacific and Atlantic time-series stations, Mar. Chem., 113, 63-77, 2009.

Kim, S., Simpson, A. J., Kujawinski, E. B., Freitas, M. A., and Hatcher, P. G.: High resolution electrospray ionization mass spectrometry and 2D solution NMR for the analysis of DOM extracted by C18 solid phase disk, Org. Geochem., 34, 1324-1335, 2003.

Kirchman, D. L.: Leucine incorporation as a measure of biomass production by heterotrophic bacteria, in: Handbook of Methods in Aquatic Microbial Ecology, edited by: Kemp, P. F., Sherr, B. F., Sherr, B. E., Cole, J. J, Boca Raton: Lewis Publishers, 509-512, 1993.

Koch, B. P., Witt, M. R., Engbrodt, R., Dittmar, T., and Kattner, G.: Molecular formulae of marine and terrigenous dissolved organic matter detected by electrospray ionization Fourier transform ion cyclotron resonance mass spectrometry, Geochim. Cosmochim. Acta, 69, 3299-3308, 2005.

Koch, B. P., Dittmar, T., Witt, M., and Kattner, G.: Fundamentals of molecular formula assignment to ultrahigh resolution mass data of natural organic matter, Anal. Chem., 79, 1758-1763, 2007.

Kujawinski, E. B., Longnecker, K., Blough, N. V., Del Vecchio, R., Finlay, L., Kitner, J. B., and Giovannoni, S. J.: Identification of possible source markers in marine dissolved organic matter using ultra high resolution mass spectrometry, Geochim. Cosmochim. Acta, 73, 4384-4399, 2009.

Loh, A. N., Bauer, J. E., and Druffel, E. R. M.: Variable ageing and storage of dissolved organic components, Nature, 430, 877-881, 2004.

Ogawa, H. and Tanoue, E..: Dissolved organic matter in oceanic waters, J. Oceanogr., 59, 129-147, 2003.

Ogawa, H., Fukuda, R., and Koike, I.: Vertical distributions of dissolved organic carbon and nitrogen in the Southern Ocean, Deep-Sea Res. I, 46, 1809-1826, 1999.

Ogawa, H., Amagai, Y., Koike, I., Kaiser, K., and Benner, R.: Production of refractory dissolved organic matter by bacteria, Science, 292, 917-920, 2001.

Piontek, J., Händel, N., Langer, G., Wohlers, J., Riebesell, U.,and Engel, A.: Effects of rising temperature on the formation and microbial degradation of marine diatom aggregates, Aquat. Microb. Ecol., 54, 305-318 2009.

Piontek, J., Lunau, M., Händel, N., Borchard, C., Wurst, M., and Engel, A.: Acidification increases microbial polysaccharide degradation in the ocean, Biogeosci., 7, 1615-1624, 2010.

Repeta, D. J. and Aluwihare, L. I.: Radiocarbon analysis of neutral sugars in high-molecular-weight dissolved organic carbon: implications for organic carbon cycling, Limnol. Oceanogr., 51, 1045-1053, 2006. 
Santschi, P. H., Guo, L. D., Baskaran, M., Trumbore, S., Southon, J., Bianchi, T. S., Honeyman, B., and Cifuentes, L.: Isotopic evidence for the contemporary origin of high-molecular weight organic matter in oceanic environments, Geochim. Cosmochim. Acta, 59, 625-631, 1995.

Schmidt, F., Elvert, M., Koch, B. P., Witt, M., and Hinrichs, K.-U.: Molecular characterization of dissolved organic matter in pore water of continental shelf sediments, Geochim. Cosmochim. Acta, 73, 3337-3358, 2009.

Sleighter, R. L. and Hatcher, P. G.: Molecular characterization of dissolved organic matter (DOM) along a river to ocean transect of the lower Chesapeake Bay by ultrahigh resolution electrospray ionization Fourier transform ion cyclotron resonance mass spectrometry, Mar. Chem., 110, 140-152, 2008.

Smith, D. C. and Azam, F.: A simple, economical method for measuring bacterial protein synthesis rates in seawater using ${ }^{3}$ H-leucine, Mar. Microb. Food Webs, 6, 107-114, 1992.

Sofer, Z.: Preparation of carbon dioxide for stable carbon isotope analysis of petroleum fractions, Anal. Chem., 52, 1389-1391, 1980.
Stenson, A. C., Marshall, A. G., and Cooper, W. T.: Exact masses and chemical formulas of individual Suwanee river fulvic acids from ultrahigh resolution electrospray ionisation Fourier transform ion cyclotron resonance mass spectra, Anal. Chem., 75, 1275-1284, 2003.

Stuiver, M. and Polach, H. A.: Discussion: Reporting of ${ }^{14} \mathrm{C}$ data, Radiocarb., 19, 355-363, 1977.

Tans, P., NOAA/ESRL; available at: www.esrl.noaa.gov/gmd/ccgg/ trends, 2010.

Taylor, B. B., Torrecilla, E., Bernhardt, A., Taylor, M. H., Peeken, I., Röttgers, R., Piera, J., and Bracher, A.: Bio-optical provinces in the eastern Atlantic Ocean and their biogeographical relevance, Biogeosciences, 8, 3609-3629, doi:10.5194/bg-8-3609-2011, 2011.

Vogel, J. S., Nelson, D. E., and Southon, J. R.: ${ }^{14} \mathrm{C}$ background levels in an accelerator mass spectrometry system, Radiocarb., 29, 323-333, 1987.

Williams, P. M. and Druffel, E. R. M.: Radiocarbon in dissolved organic matter in the central North Pacific Ocean, Nature, 330, 246-248, 1987.

Witt, M., Fuchser, J., and Koch, B. P.: Fragmentation studies of fulvic acids using collision induced dissociation Fourier transform ion cyclotron resonance mass spectrometry, Anal. Chem., 81, 2688-2694, 2009. 